\title{
AVALIAÇÃO DE DESEMPENHO DO REATOR \\ ANAERÓBIO EM BATELADA SEQÜENCIAL (ASBR), \\ CONTENDO BIOMASSA IMOBILIZADA EM PEDRA \\ POME, PARA TRATAMENTO DE ESGOTO SANITÁRIO
}

\section{Katt Regina Lapa}

Dissertação apresentada à Escola de Engenharia de São Carlos, da Universidade de São Paulo, como parte dos requisitos para obtenção do título de Mestre em Engenharia Civil - Hidráulica e Saneamento

ORIENTADOR: Prof. Tit. Eugenio Foresti 
"R eparta seu conhecimento. É uma forma dealcançar a imortalidade"

\author{
"L embrese: \\ grandes amorese \\ grandes conquistas \\ envolvem riscos."
}

(anônimo) 


\title{
D edico este estudo
}

\section{A osmeus $\mathrm{P}$ aiş, $\mathrm{A}$ ilson eA cácia, pelo passado que herdè}

\begin{abstract}
A o meu amor $\mathrm{L}$ uis $\mathrm{H}$ amilton, pelo presente que desfruto $\mathrm{e}$
\end{abstract}

A o meu filho L ucas, pelo futuro que edificarei! 


\section{AGRADECIMENTOS}

À minha família, a quem agradeço de coração, pela ajuda e pelo constante incentivo.

Ao Adilson Pinheiro pelo incentivo durante a iniciação científica na Universidade Regional de Blumenau-SC e por ter despertado em mim o interesse para estudar saneamento.

Ao Eugenio Foresti pela orientação no desenvolvimento e conclusão deste trabalho e ao Marcelo Zaiat pela colaboração, auxílio e sugestões durante todo o mestrado.

À Elisabeth Moraes pelo auxílio nas questões químicas e correção do texto, Ruth de Gouvêa Duarte pelo auxílio na correção do texto e Eloísa P. Gianotti pelo auxílio nos exames microscópicos.

Aos grandes irmãos Selma A. Cubas e Edson R. Pereira pela amizade e valiosa ajuda pessoal e profissional.

A todos os amigos do mestrado, das disciplinas e do Laboratório de Processos Biológicos e as amigas Ana Paula Miqueleto, Andréa Luiza da Silva e Júlia S. Hirasawa.

À Sávia G. dos Santos, Samantha C. Pinho e Rogers Ribeiro pela amizade, cooperação e sugestões para conclusão da dissertação e ao Ariovaldo J. Silva, Arnaldo Sarti e Marcelo L. Garcia pela colaboração na fase experimental.

Às profissionais do Laboratório de Processos Biológicos Maria Ângela T. Adorno e Maria B. Varesche pela permanente disposição em atender meus pedidos de ajuda durante a fase experimental deste trabalho.

Às secretárias do Curso de pós-graduação em Hidráulica e Saneamento.

Aos funcionários do LATAR e do laboratório de saneamento da EESC.

Aos funcionários da Oficina Mecânica da EESC que foram fundamentais para a montagem da instalação experimental.

Ao CNPq pela bolsa de mestrado e à FAPESP pelo apoio financeiro.

A todos aqueles que, de alguma forma, contribuíram para a realização deste trabalho. 


\section{SUMÁRIO}

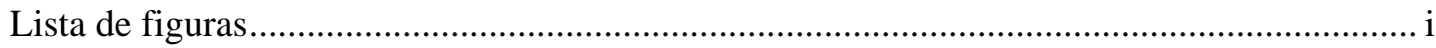

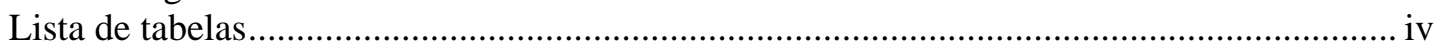

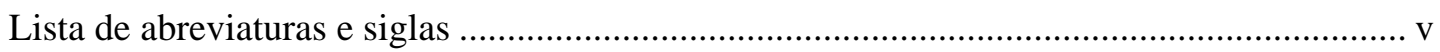

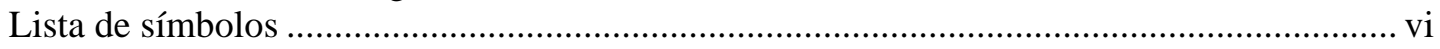

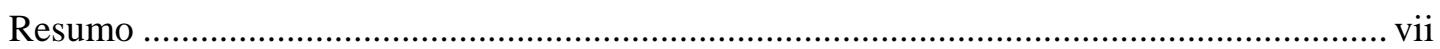

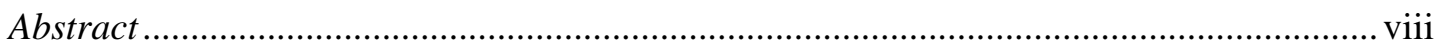

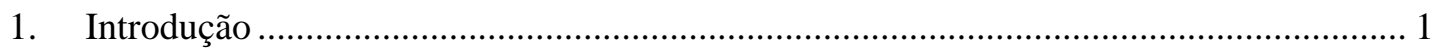

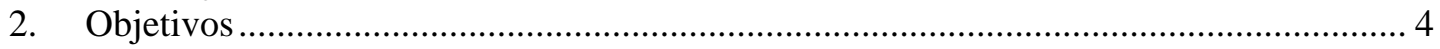

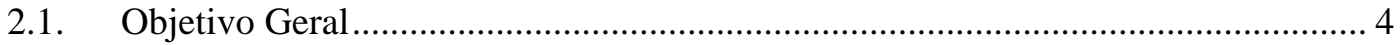

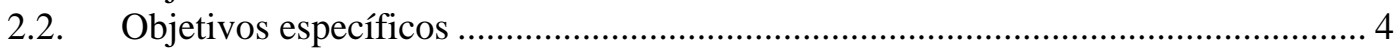

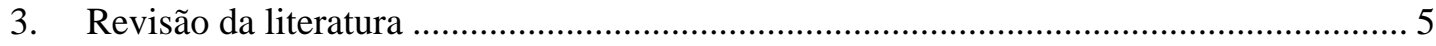

3.1. Reator anaeróbio em batelada seqüencial .......................................................... 6

3.1.1. Desenvolvimento do reator anaeróbio em batelada seqüencial ....................... 6

3.1.2. Características do reator anaeróbio em batelada seqüencial .............................. 6

3.1.3. Estudos com reator anaeróbio em batelada seqüencial convencional................ 8

3.1.4. Melhoramentos no Reator anaeróbio em batelada seqüencial ....................... 14

3.1.4.1. Reator anaeróbio em batelada seqüencial com biomassa imobilizada

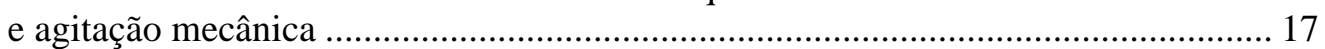

3.1.5. Ampliação de escala do reator anaeróbio em batelada seqüencial................. 19

3.1.6. Comparação ASBR e UASB ....................................................................... 20

3.1.7. Cinética microbiana no reator anaeróbio em batelada seqüencial .................. 21

3.2. Reatores anaeróbios com biomassa imobilizada em materiais suportes inertes .... 24

3.3. Pedra pome utilizada como material suporte ........................................................ 26

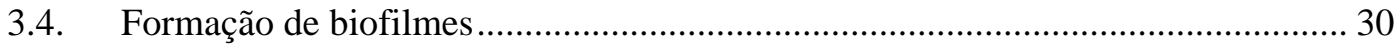

3.5. Microbiologia em reatores anaeróbios ................................................................. 34

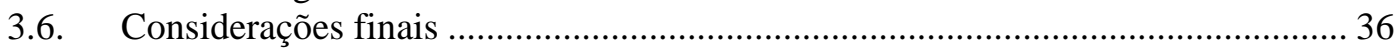

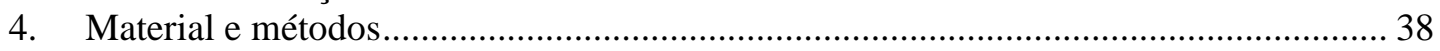

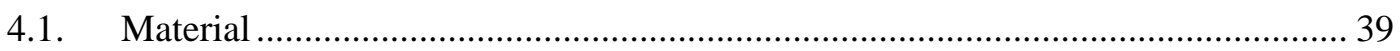

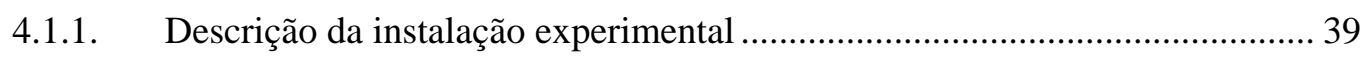

4.1.1.1. Local de instalação e operação do sistema................................................ 39

4.1.1.2. Configuração do reator anaeróbio em batelada seqüencial ..................... 40

4.1.2. Material suporte para imobilização da biomassa - pedra pome...................... 41

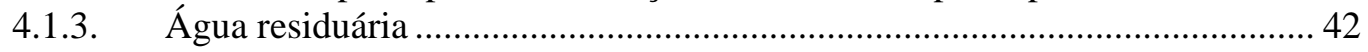

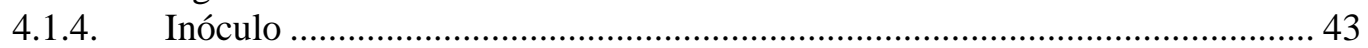

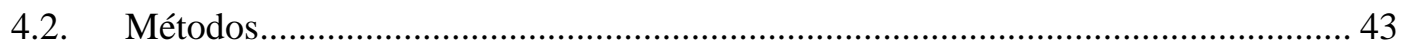

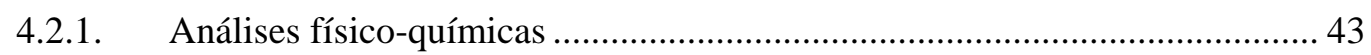

4.2.2. Quantificação e composição dos gases .......................................................... 44

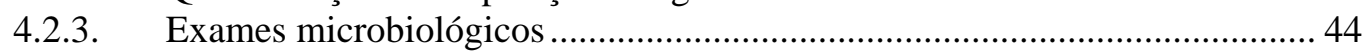

4.2.4. Procedimento experimental.................................................................. 45

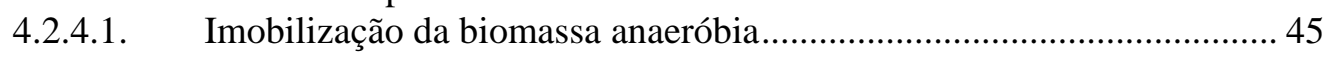

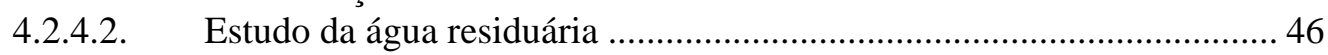

4.2.4.3. Caracterização do material suporte - pedra pome sintética .................... 46

4.2.4.4. Quantificação da biomassa aderida...................................................... 47

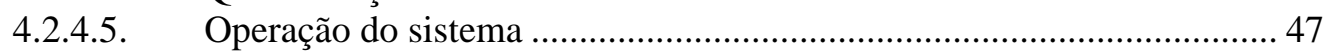

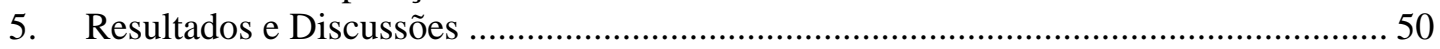

5.1. Perfis temporais da água residuária afluente....................................................... 50

5.2. Caracterização do material suporte - pedra pome sintética ………………............. 51

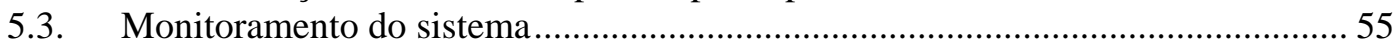

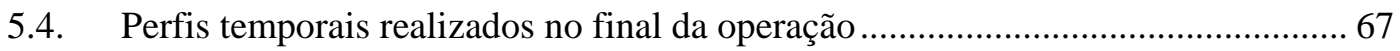

5.5. Obtenção de parâmetros cinéticos aparentes.......................................................... 72 


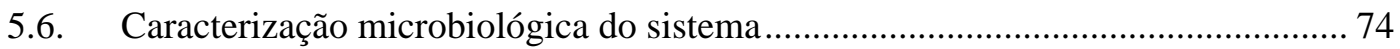

5.6.1. Morfologias encontradas no lodo utilizado como inóculo ............................ 74

5.6.2. Morfologias encontradas no material suporte ............................................... 76

5.6.2.1. Morfologias presentes no material suporte aos 62 dias de operação ..... 76

5.6.2.2. Morfologias presentes no lodo na superfície do cesto de imobilização ..................................................................................................... 78

5.6.2.3. Morfologias presentes no material suporte no final da operação ............ 79

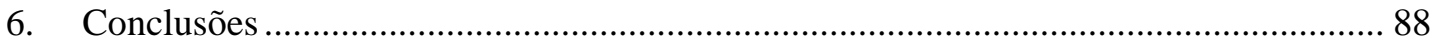

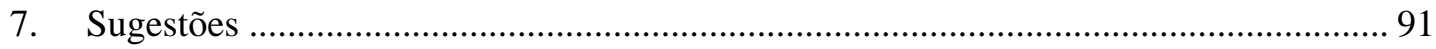

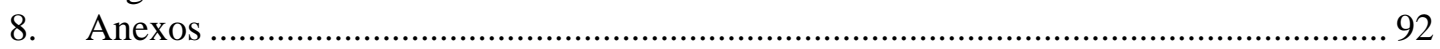

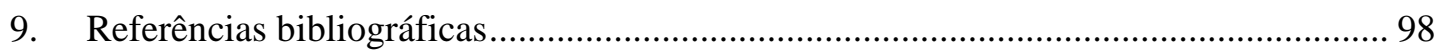




\section{LISTA DE FIGURAS}

FIGURA 3.1 - Tipos de agitadores: (a) Turbina, lâminas planas verticais; (b) turbina, lâminas planas inclinadas; (c) turbina, lâminas curvas; (d) turbina, disco com lâminas planas; (e) turbina, disco com lâminas curvas; (f) turbina, ventoinha; (g) hélice e (h) palheta. Fonte: BORZANI et al., (1986). .......... 15

FIGURA 3.2 - Pirâmide da composição da pedra pome sintética. .......................................... 26

FIGURA 3.3 - Esquema de produção do concreto celular autoclavado - pedra pome sintética. (1) britador de mandíbula; (2) moinho de bolas; (3) silo com lama quartizoza; (4) silo de dosagem dos compostos; (5) processo de hidratação e formação de poros; (6) corte dos blocos; (7) autoclave; (8) bloco proto para o comércio e (9) estocagem................................................ 27

FIGURA 3.4 - Ciclo de desenvolvimento do biofilme. ........................................................ 32

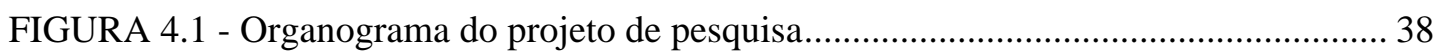

FIGURA 4.2 - Mapa do Campus da Universidade de São Paulo - São Carlos - SP. Detalhe da localização da instalação experimental, demarcada como E.T.E. (em verde).

FIGURA 4.3 - Esquema do aparato experimental, sendo (1) reator anaeróbio em batelada seqüencial, (2) camisa de aquecimento, (3) cesto inox, (4) agitador mecânico, (5) Impelidor, (6) bomba de diafragma alimentação, (7) bomba de diafragma - descarga, (8) banho ultratermostatizado, (9) amostrador e (10) bancada.

FIGURA 4.4 - (a) Cesto de tela de inox vazio e (b) pedra pome sintética, antes da inoculação.

FIGURA 4.5 - Sistema de coleta e armazenamento do esgoto sanitário afluente: (a) rede de esgoto sanitário, ponto de captação, (b) bomba de recalque e (c) caixa de armazenamento.

FIGURA 4.6 - (a) Instalação experimental, (b) reator anaeróbio em batelada seqüencial, (c) agitador mecânico, (d) haste com impelidores, (e) bomba de carga e descarga, (f) timers e (g) caixa de amostragem e bomba amostradora.

FIGURA 5.1 - Perfis temporais da concentração de esgoto sanitário no reservatório de $750 \mathrm{~L}$.

FIGURA 5.2 - Microscopia eletrônica de varredura de amostras da pedra pome. (a) Superfície porosa com aumento de $35 \mathrm{X}$; (b) ampliação da superfície para 100X, que evidencia a forma e profundidade dos poros; (c) poros de constituição rugosa e irregular, como diversas irregularidades, aumento de 1000X; e (d) ampliação da foto (c) evidenciando estrutura cristalina característica de cristais de cimento.

FIGURA 5.3 - Difratograma da amostra de pedra pome. As fases cristalinas identificáveis são: quartzo $\left(\mathrm{SiO}_{2}\right)$, tobermorita $\left[\mathrm{Ca}_{5} \mathrm{Si}_{6}(\mathrm{O}, \mathrm{OH}, \mathrm{F})_{18^{-}}\right.$ $\left.5 \mathrm{H}_{2} \mathrm{O}\right]$ e calcita $\left(\mathrm{CaCO}_{3}\right)$.

FIGURA 5.4 - Variação do pH no afluente e efluente, durante o período estudado.. 
FIGURA 5.5 - Esquema de filtração de DQO para obtenção das frações particuladas, coloidais e solúveis.

FIGURA 5.6 - Concentração da DQO em amostras totais e filtradas de afluente e efluente.

FIGURA 5.7 - Concentrações de DQO fracionada em total, particulada, coloidal e solúvel, durante o período estudado.

FIGURA 5.8 - Eficiências de remoção de matéria orgânica fracionada durante o período de trabalho.

FIGURA 5.9 - Valores de Alcalinidade a bicarbonato e de ácidos voláteis totais durante o período.

FIGURA 5.10 - Concentração de sólidos totais e sólidos totais voláteis durante o período

FIGURA 5.11 - Variação das concentrações de sólidos suspensos totais e sólidos suspensos voláteis no monitoramento do reator.

FIGURA 5.12 - Variação das concentrações de sólidos dissolvidos totais e sólidos dissolvidos voláteis no monitoramento do reator.

FIGURA 5.13 - Perfis temporais de pH e de potencial de oxi-redução.

FIGURA 5.14 - Perfil temporal de demanda química de oxigênio total, filtrada \#1,2 e filtrada \#0,45.

FIGURA 5.15 - Perfil temporal de demanda química de oxigênio na forma de DQO particulada, coloidal e solúvel.

FIGURA 5.16 - Perfil temporal de alcalinidade a bicarbonato e ácidos voláteis totais.

FIGURA 5.17 - Perfis ajustados para obtenção dos parâmetros cinéticos de (a) DQO total, (b) DQO particulada, (c) DQO coloidal e (d) DQO solúvel.

FIGURA 5.18 - Morfologias presentes no inóculo, através de microscopia ótica, com aumento de 1.250x: (a1) cocos em tétrades; (a6), (a10), (b3) e (b6) cocos; (a2) bacilos retos; (a3) e (b4) bacilos alongados; (b1) bacilos em cadeia; (a4), (a7) e (b5) bacilos com extremidades arredondadas; (a5) víbrio; (a8) filamento; (a9) e (b2) microrganismos semelhantes a Methanosaeta sp; (c1) e (c2) cocos fluorescentes; (d) bacilos fluorescentes; (e) e (f) microrganismos semelhantes a cistos de Methanosarcinas sp.

FIGURA 5.19 - Morfologias presentes no material suporte aos 62 dias de operação (149 ciclos), através de microscopia ótica, com aumento de $1.500 \mathrm{x}$, semelhantes a: (a1) espiroqueta; (a2) filamento; (a3) bacilos com extremidades arredondadas; (a4) cocos; (a5) bacilos ovalados; (b) bacilos alongados com inclusões; (c) filamentos com inclusões; (d) célula fotoanoxigênica; (e) microrganismos semelhantes a Methanosarcinas sp.; (f) bacilos fluorescentes.

FIGURA 5.20 - Morfologias presentes no material suporte aos 62 dias de operação (149 ciclos), através de microscopia eletrônica de varredura, com aumento de 5.000x, semelhantes a: (a) cocos e bacilos de diversas dimensões; (b1) cocos; (b2) bacilos agrupados; (b3) microrganismo semelhante a Methanosarcina sp. 
FIGURA 5.21 - Morfologias presentes no lodo superficial formado acima do cesto de imobilização, através de microscopia ótica, semelhantes a: (a) cocos e bacilos de diversas dimensões, aumento de 1.500x; (b) rotífero, aumento de 150x; (c) Paramecium sp., aumento de 150x; (d) nematóide, aumento de 150x; (e) microrganismo semelhante a Beggiatoa sp., aumento de $1.500 x$; (f) microrganismo semelhante a Sphaerotilus sp., aumento de 1.500x...

FIGURA 5.22 - Morfologias presentes no material suporte na superfície do reator, através de microscopia ótica, com aumento de $1.500 \mathrm{x}$, semelhantes a: (a) bacilos de diversas dimensões; (b1) bactéria fotoanoxigênica; (b2) bacilos semelhantes a BRS; (c) bacilos alongados com inclusões; (d) morfologias semelhantes a cocos fluorescentes; (e) microrganismos semelhantes a Chromatium sp.; (f1) bacilos em cadeia; (f2) microrganismo semelhante a Methanosaeta sp.

FIGURA 5.23 - Morfologias presentes no material suporte no centro do reator, através de microscopia ótica, com aumento de 1.500x, semelhantes a: (a) e (b) bacilos semelhantes a BRS; (c) células fotoanoxigênicas, semelhantes a Chromatium sp.; (d) microrganismos semelhantes a Methanosaeta sp.; (e) bacilos fluorescentes; (f) microrganismos semelhantes a Methanosarcina sp.

FIGURA 5.24 - Morfologias presentes no material suporte no fundo do reator, através de microscopia ótica, com aumento de 1.500x, semelhantes a: (a) e (b1) bacilos semelhantes a BRS; (b2) cocos; (b3) víbrio; (c) bacilos de diversas morfologias; (d) microrganismo semelhante a Methanosaeta sp.; (e) bacilos fluorescentes metanogênicos.

FIGURA 5.25 - Morfologias presentes no material suporte no final da operação, através de microscopia eletrônica de varredura, semelhantes a: (a1) e (b3) bacilos arredondados; (a2) e (b1) cocos (a3) bacilos longos em cadeia; (b2) bacilos em cadeia; (c) bacilos arredondados, semelhantes a Chromatium sp.; (d) microrganismo semelhante a Methanosarcina sp.; (e) e (f) microrganismo semelhante a Methanosaeta sp.

FIGURA 5.26 - Morfologias presentes no lodo remanescente no fundo do reator, através de microscopia ótica, com aumento de $1.500 \mathrm{x}$, semelhantes a: (a1) bacilo alongado com inclusões; (a2) bacilos afilados; (a3) bacilos delgados; (b) microrganismo semelhante a Methanosaeta sp. (c) microrganismo semelhante a Methanosarcina sp.; (d) bacilos fluorescentes metanogênicos. 


\section{LISTA DE TABELAS}

TABELA 3.1 - Comparação entre sistema UASB e ASBR ..................................................... 21

TABELA 3.2 - Parâmetros cinéticos obtidos para faixa de dados estudados......................... 21

TABELA 3.3 - Parâmetros cinéticos medidos para várias temperaturas............................... 22

TABELA 3.4 - Parâmetros cinéticos de primeira ordem obtidos para diferentes velocidades de agitação magnética............................................................... 23

TABELA 3.5 - Parâmetros cinéticos de primeira ordem obtidos para diferentes velocidades de agitação mecânica................................................................ 23

TABELA 5.1 - Dados obtidos das análises de caracterização da pedra pome........................ 52

TABELA 5.2 - Valores obtidos nas análises de dureza e teor de cálcio...................................65

TABELA 5.3 - Parâmetros do ajuste da expressão de primeira ordem com residual............. 73

TABELA 5.4 - Morfologias dos microrganismos presentes no inóculo e pedra pome imobilizada aos dois meses e no final da operação....................................... 87

ANEXO A - Tabela de monitoramento da demanda química de oxigênio (DQO), total e

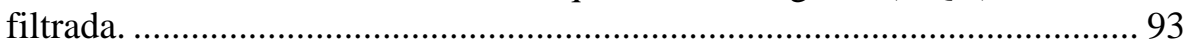

ANEXO C - Tabela de DQO fracionada em DQO particulada, coloidal e solúvel. ............... 94

ANEXO D - Tabela com valores de alcalinidade a bicarbonato e ácidos voláteis totais....... 95

ANEXO E - Tabela do monitoramento de sólidos totais, suspensos e dissolvidos. ............... 96

ANEXO F - Tabela com valores obtidos nos perfis temporais para $\mathrm{pH}, \mathrm{DQO}, \mathrm{POR}, \mathrm{AB}$

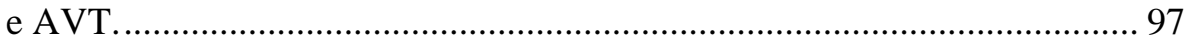




\section{LISTA DE ABREVIATURAS E SIGLAS}

$\mathrm{AB}$

ASBR

AVT

BRS

CNPQ

COV

DQO

FAPESP

MEV

PEC

$\mathrm{S} / \mathrm{M}$

SDF

SDT

SDV

$\mathrm{SF}$

SSF

SST

SSV

ST

SV

TDH

TRC

UASB

E.T.E.

SS

POR

GTA

CCDM

UFScar
- Alcalinidade a bicarbonato

- Anaerobic Sequencing Batch Reactor (reator anaeróbio em batelada sequencial)

- Ácidos voláteis totais

- Bactéria(s) redutora(s) de sulfato

- Conselho Nacional de Pesquisa

- Carga orgânica volumétrica

- Demanda química de oxigênio

- Fundação de Amparo a Pesquisa de São Paulo

- Microscopia eletrônica de varredura

- Polímeros extracelulares

- Substrato/microrganismo

- Sólidos dissolvidos fixos

- Sólidos dissolvidos totais

- Sólidos dissolvidos voláteis

- Sólidos fixos

- Sólidos suspensos fixos

- Sólidos suspensos totais

- Sólidos suspensos voláteis

- Sólidos totais

- Sólidos voláteis

- Tempo de detenção hidráulica

- Tempo de retenção celular

- Upflow Anaerobic Sludge Blanket (reator anaeróbio de fluxo ascendente e manta de lodo)

- Estação de tratamento de esgoto

- Sólidos suspensos

- Potencial de oxi-redução

- Glutaraldeído

- Centro de Caracterização e Desenvolvimento de Materiais

- Universidade Federal de São Carlos 


\section{LISTA DE SÍMBOLOS}

\begin{tabular}{|c|c|}
\hline $\mathrm{C}_{\mathrm{S} 0}$ & - Concentração inicial de substrato [mg/L] \\
\hline $\mathrm{Ca}(\mathrm{OH})_{2}$ & - Hidróxido de cálcio \\
\hline $\mathrm{Ca}^{+2}$ & - Íon cálcio \\
\hline \multicolumn{2}{|c|}{$\mathrm{Ca}_{5} \mathrm{Si}_{6}(\mathrm{O}, \mathrm{OH}, \mathrm{F})_{18} 5 \mathrm{H} 2 \mathrm{O}$ - Tobermorita } \\
\hline $\mathrm{CaCO}_{3}$ & - Calcita ou carbonato de cálcio \\
\hline $\mathrm{CaO}$ & - Óxido de cálcio \\
\hline $\mathrm{CH}_{3} \mathrm{COO}^{-}$ & - Acetato \\
\hline $\mathrm{CH}_{3} \mathrm{COOH}$ & - Ácido acético \\
\hline $\mathrm{CO}_{2}$ & - Gás carbônico ou dióxido de carbono \\
\hline $\mathrm{CO}_{3}^{-}$ & - Carbonato \\
\hline $\mathrm{C}_{\mathrm{S}}$ & - Concentração de substrato [mg/L] \\
\hline $\mathrm{C}_{\mathrm{SR}}$ & - Concentração residual de substrato [mg/L] \\
\hline $\mathrm{H}^{+}$ & - Prótons \\
\hline $\mathrm{H}_{2} \mathrm{CO}_{3}$ & - Ácido carbônico \\
\hline $\mathrm{H}_{2} \mathrm{O}$ & - Água \\
\hline $\mathrm{H}_{2} \mathrm{~S}$ & - Ácido sulfídrico \\
\hline $\mathrm{HCO}_{3}^{-}$ & - Bicarbonato \\
\hline $\mathrm{k}_{1}^{\mathrm{ap}}$ & - Coeficiente cinético aparente de primeira ordem $\left[\mathrm{h}^{-1}\right]$ \\
\hline $\mathrm{K}_{\mathrm{di}}$ & - Constante de morte celular $\left[\mathrm{dia}^{-1}\right]$ \\
\hline $\mathrm{k}_{\max }$ & - Velocidade específica máxima de remoção de substrato $\left[\operatorname{dia}^{-1}\right]$ \\
\hline $\mathrm{K}_{\mathrm{p}}$ & - Taxa de solubilização de primeira ordem $\left[\mathrm{dia}^{-1}\right]$ \\
\hline $\mathrm{K}_{\mathrm{S}}$ & - Coeficiente de meia-velocidade de saturação [mg/L] \\
\hline $\mathrm{OH}^{-}$ & - Hidroxila \\
\hline $\mathrm{R}^{2}$ & - Coeficiente de correlação \\
\hline $\mathrm{R}_{\mathrm{S}}$ & - Velocidade de consumo de substrato [mg/L] \\
\hline $\mathrm{SiO}_{2}$ & - Quartzo ou dióxido de silício \\
\hline $\mathrm{t}$ & - Tempo [h] \\
\hline $\mathrm{TiO}_{2}$ & - Dióxido de titânio \\
\hline $\mathrm{V}_{\max . \mathrm{i}}$ & - Velocidade específica máxima de DQO solúvel [mg/mg.dia] \\
\hline $\mathrm{Y}_{\mathrm{i}}$ & - Fator de rendimento $[\mathrm{mg} / \mathrm{mg}]$ \\
\hline
\end{tabular}




\section{RESUMO}

LAPA, K.R. (2003). Avaliação de desempenho do reator anaeróbio em batelada seqüencial contendo biomassa imobilizada em pedra pome para tratamento de esgoto sanitário. 106p. Dissertação (Mestrado) - Escola de Engenharia de São Carlos, Universidade de São Paulo.

Os reatores anaeróbios em batelada (ASBR) de leito fixo, em desenvolvimento no Instituto Mauá de Tecnologia e na Escola de Engenharia de São Carlos, têm apresentado desempenho satisfatório no tratamento de esgotos sanitários. A escolha do leito suporte é um dos importantes aspectos dessa etapa de desenvolvimento, além do aprofundamento do conhecimento dos aspectos fundamentais do processo e daqueles relacionados à operação do reator. Esta investigação estudou o comportamento de um ASBR de leito fixo, em escala de bancada, formado por matrizes de pedra pome, para suporte da biomassa, provido de agitador mecânico, no tratamento de esgotos sanitários coletados no Campus da USP, em São Carlos. O reator, com volume total de 7,2 L, foi operado em ciclos de 8 horas de duração, durante 86 dias, totalizando 216 ciclos. A DQO média afluente, no período, foi de $446 \pm 169 \mathrm{mg} / \mathrm{L}$, com valores médios, no efluente, respectivamente iguais a $233 \pm 52,64 \pm$ 31, $32 \pm 15$ e $141 \pm 32 \mathrm{mg} / \mathrm{L}$ para a DOQ total, fração particulada, coloidal e solúvel. Esses valores confirmam o bom desempenho do reator na remoção da fração particulada da matéria orgânica (eficiência de remoção de 84\%). O modelo cinético para a velocidade de decaimento da DQO, que melhor se ajustou aos dados experimentais foi o de primeira ordem

com residual $\left(\mathrm{k}_{1}{ }^{\text {ap }}=0,63 \pm 0,06 \mathrm{~h}^{-1}\right)$. Apesar do bom desempenho do reator, a presença, no efluente, de concentrações elevadas de sólidos solúveis fixos e valores anormais de alcalinidade e $\mathrm{pH}$, alertaram para a necessidade de estudo mais aprofundado do leito, concluindo-se que a pedra pome sintética não apresenta a estabilidade química necessária para seu uso como material suporte nesse tipo de reator, pois ocorreu a perda contínua de cálcio do leito que resultou na perda da estabilidade estrutural das matrizes.

Palavras-chave: esgotos sanitários; tratamento biológico; processo anaeróbio; reator ASBR; biomassa imobilizada; pedra pome. 


\section{ABSTRACT}

LAPA, K.R. (2003). Performance evaluation of a stirred anaerobic sequencing batch reactor containing immobilized biomass in pumice stone for wastewater treatment. 106p. Dissertação (Mestrado) - Escola de Engenharia de São Carlos, Universidade de São Paulo.

The anaerobic sequencing batch reactors (ASBR) with immobilized biomass, that are under development at Mauá Institute of Technology and at São Carlos Engineering School, presented good performance in the wastewater treatment. Recent researches are trying to improve this reactor design and operation. The choice of the support material is one of the important aspects of this development stage, besides the knowledge enhancement of the fundamental process aspects and the ones related with the reactor operation and its influence in the performance. This work presents the results of the ASBR operation and their influence in its performance, in bench scale, filled with pumice stones matrices used as biomass support. The reactor was provided with a mechanical agitator to treat the sewage collected at USP-São Carlos. The reactor volume was 7,2 liters and was operated with 8 hours duration cycles, during 86 days, totalizing 216 cycles. The mean inflow COD was $446 \pm 169 \mathrm{mg} / \mathrm{L}$, obtaining mean values, in the effluent, respectively equal to a $233 \pm 52,64 \pm 31,32 \pm 15$ e $141 \pm 32 \mathrm{mg} / \mathrm{L}$ for total COD, particulate fraction, colloidal fraction and soluble fraction. This data confirm the good reactor performance in the removal of the particulate fraction of the organic matter (removal efficiency of $84 \%$ ). The kinetic model for the COD decay rate that best fit the experimental data was a first order model with residual $\left(\mathrm{k}_{1}{ }^{\mathrm{ap}}=0,63 \pm 0,06 \mathrm{~h}^{-1}\right)$. Despite of the good reactor performance, the high fixed soluble solids concentration in the effluent, as the abnormal alkalinity and $\mathrm{pH}$ values, took the matrices study further. It was concluded that the synthetic pumice stones, does not present a chemical stability necessary for its use as support material in this kind of reactor, because the matrices continuously lost calcium, resulting in the lost of its structural stability.

Key-words: wastewater; biological treatment; anaerobic process; ASBR reactor; immobilized biomass; pumice stone. 


\section{INTRODUÇÃ̃o}

Entre os muitos sistemas de tratamento que utilizam processos físico-químicos e biológicos, destacam-se os processos biológicos anaeróbios, por possuírem vantagens significativas se comparados aos processos aeróbios convencionais. Essas vantagens incluem, principalmente, a baixa produção de lodo a ser descartado, devido ao baixo rendimento das reações catabólicas. No processo de digestão anaeróbia ocorrem os processos de respiração na ausência de oxigênio e fermentação. Na respiração, carbonatos, nitratos e sulfatos podem ser os aceptores finais de elétrons, resultando compostos reduzidos de carbono, nitrogênio e enxofre. Os principais produtos da fermentação anaeróbia metanogênica são os ácidos orgânicos e os gases metano e carbônico. O lodo excedente, quantitativamente menor que o produzido nos processos aeróbios, possui alto grau de estabilização. O gás metano produzido pode ser utilizado como fonte de energia.

Existe, atualmente, crescente consciência que poluição e contaminação do meio ambiente são indesejáveis e, portanto, devem ser tomadas medidas para diminuí-las do ponto de vista ecológico, e não simplesmente pelos melhoramentos que possam trazer às condições de vida humana. O aumento da demanda por sistemas de tratamento de esgotos sanitários estimulou a pesquisa e a adoção de métodos alternativos de tratamento, em substituição aos sistemas tradicionalmente empregados, geralmente, grandes consumidores de energia e produtores de grandes quantidades de lodo. Dadas as vantagens apresentadas, em tese, pelos processos anaeróbios, busca-se o desenvolvimento de novas configurações de sistemas de tratamento de águas residuárias, nos quais as unidades anaeróbias são parte essencial na remoção de matéria orgânica. Estudos de aspectos cinéticos, hidrodinâmicos e 
microbiológicos permitem maior conhecimento do processo, para tornar viável o desenvolvimento de concepções de projetos de unidades de tratamento que aproveitem, ao máximo, o volume útil reacional, com a conseqüente diminuição do volume total, para melhorarem o desempenho e a estabilidade do processo e que sejam de fácil operação.

A biotecnologia anaeróbia tem se desenvolvido de forma extraordinária, quer pela utilização de reatores que contêm biomassa imobilizada, com formação de biofilme aderido a material suporte, ou pela formação de lodo granular. Os reatores de filme fixo e os que desenvolvem lodo granular permitem melhor retenção do lodo no sistema. Nessas condições, o tempo de detenção hidráulica (TDH) pode se tornar independente do tempo de retenção celular (TRC). No caso de reatores de leito fixo, há possibilidade de ser mais efetivo o contato dos microrganismos com o substrato, com conseqüente diminuição do volume reacional, o que os torna economicamente mais viáveis.

Uma nova configuração proposta para reatores anaeróbios aplicados ao tratamento de águas residuárias consiste na operação de forma descontínua, pois apresenta grandes vantagens e potencial de utilização para diversas águas residuárias domésticas e industriais. Richard R. Dague e sua equipe, da Universidade do Estado de Iowa - U.S.A., em 1992 (DAGUE et al., 1992), desenvolveram o reator anaeróbio em batelada seqüencial, patenteado sob número 5.185.079 (SCHMIT \& DAGUE, 1993). Desde então, foram realizados diversos estudos que confirmaram as vantagens do processo descontínuo (DAGUE et al.,1992; FERNANDES et al., 1993; SUNG \& DAGUE, 1995; ANGEMENT \& DAGUE, 1995; TIMUR \& ÖSTURK, 1999).

No Brasil, os processos em batelada estão sendo estudados por pesquisadores do Instituto de Pesquisas Hidráulicas - IPH/UFRGS, do Departamento de Engenharia Química e de Alimentos da Escola de Engenharia de Mauá - DQA/EEM/IMT e do Departamento de Hidráulica e Saneamento da Escola de Engenharia de São Carlos - SHS/EESC/USP. O SHS/EESC/USP e o DQA/EEM/IMT desenvolvem pesquisas em conjunto, desde 1998, com apoio da FAPESP. Assim, através do Programa de Jovens Pesquisadores em Centros 
Emergentes do DQA/EEM/IMT (FAPESP Processo 97/05987-3), foi concebido e testado o reator anaeróbio em batelada sequiencial utilizando células imobilizadas, com enfoque voltado à otimização e aplicação dessa nova tecnologia (RATUSZNEI et al., 2000).

No SHS/EESC/USP diversas pesquisas estão sendo realizadas com esse tipo de reator, na busca de melhor compreensão dos aspectos fundamentais dos processos, com vistas à ampliação de escala para uso em tratamento de despejos industriais e domésticos (CUBAS et al., 2001; PINHO et al., 2002; SARTI et al., 2002; CUBAS et al., 2002).

Este projeto de investigação para mestrado pretende estudar o desempenho do reator anaeróbio em batelada seqüencial no tratamento de esgoto sanitário, com biomassa imobilizada em material suporte - pedra pome sintética - e agitação mecânica. Enquadra-se na linha de pesquisa tecnológica por visar a análise do comportamento de diferente meio suporte para imobilização dos microrganismos, indispensáveis no tratamento biológico de águas residuárias. A escolha da pedra pome sintética, como material suporte para a biomassa, foi decorrente de algumas de suas características, consideradas vantajosas para o processo, tais como alta porosidade e resistência mecânica, além de baixo custo no mercado.

A aplicação prática desse processo depende de muitas investigações a respeito das várias características fundamentais e aspectos tecnológicos do ASBR, porque os resultados obtidos até o momento são considerados apenas indicativos e não conclusivos (ZAIAT et al., 2001). Embora ainda em estágio de desenvolvimento, seu uso se revela promissor, pois os resultados demonstram que esse tipo de reator é adequado para efluentes de baixa concentração, como é o caso dos esgotos sanitários. 


\section{OBJETIVOS}

\subsection{Objetivo Geral}

Avaliar o desempenho do reator anaeróbio em batelada seqüencial, de leito fixo de pedra pome sintética, mecanicamente agitado, no tratamento de esgoto sanitário.

\subsection{Objetivos específicos}

Frente à proposta de trabalho apresentada, os objetivos específicos da pesquisa consistem em:

- Acompanhar o desempenho do reator, avaliando-se a degradação da matéria orgânica;

- Estudar a viabilidade de utilização da pedra pome como material suporte para a biomassa em reatores anaeróbios, operados de forma descontínua.

- Proceder a caracterização microbiológica do biofilme anaeróbio por meio da observação das principais morfologias presentes sob microscopias ótica e eletrônica de varredura, ao final da fase experimental; 


\section{REVISÃO DA LITERATURA}

Neste capítulo, pretende-se apresentar revisão da literatura a respeito de tratamentos de águas residuárias em ASBR e assuntos relacionados ao objeto de pesquisa deste trabalho, como:

- Conhecimento do reator anaeróbio em batelada seqüencial: origem, característica, aplicação, modificação, ampliação de escala, comparação com outros sistemas e cinética;

- Suportes inertes utilizados em reatores anaeróbios;

- A pedra pome como material suporte;

- Aspectos da formação de biofilmes em leitos fixos;

- Aspectos da microbiologia em reatores anaeróbios.

Na última década, ocorreu ressurgimento do interesse pelo tratamento anaeróbio de águas residuárias. Esse ressurgimento pode ser devido ao crescente reconhecimento das vantagens do processo anaeróbio e ao maior entendimento dos fundamentos da microbiologia e bioquímica anaeróbia, aliado ao avanço da engenharia de processo. Esforços pioneiros no projeto de reatores têm resultado no desenvolvimento de novos reatores de alto desempenho, que podem operar com cargas orgânicas mais elevadas que as aplicadas aos digestores convencionais, bem como de sistemas capazes de tratar cargas médias e baixas de águas residuárias. Exemplos desses reatores são filtros anaeróbios, reator de leito fluidizado, reator Upflow anaerobic sludge blanket (UASB) e reator anaeróbio em batelada seqüencial (De Los REYES III \& DAGUE, 1995). 


\subsection{Reator anaeróbio em batelada seqüencial}

\subsubsection{Desenvolvimento do reator anaeróbio em batelada seqüencial}

A inspiração inicial para o processo conhecido como reator anaeróbio em batelada seqüencial - anaerobic sequencing batch reactor (ASBR) - teve origem com o trabalho de Richard R. Dague e colaboradores, em sistema anaeróbio de lodo ativado, quando, na década de 1960, observaram a importância do tempo de retenção celular (TRC) em processos anaeróbios metanogênicos (DAGUE et al., $1966^{1}$ apud SCHMIT \& DAGUE, 1993). Nesse reator, a biomassa anaeróbia floculava de modo semelhante ao que ocorre em processos de lodos ativados aeróbios e a eficiência da floculação era afetada, principalmente, pela carga orgânica volumétrica, particularmente pela razão substrato/microrganismo (S/M). Para razões baixas de $\mathrm{S} / \mathrm{M}$, a biomassa floculada sedimenta mais rapidamente e produz efluente com baixas concentrações de sólidos suspensos (DAGUE et al., 1992).

O trabalho de SCHMIT \& DAGUE (1993) com ASBR foi motivado por pesquisa anterior de Schroepfer e colaboradores, que trabalharam com água residuária de indústrias de conservas de carne usando o sistema conhecido por "processo de contato anaeróbio" (SCHROEPFER ${ }^{2}$ et al., 1955 apud SCHMIT \& DAGUE, 1993). O tratamento utilizado era semelhante ao processo anaeróbio de lodos ativados, porém, o efluente do processo de contato passava por sedimentador.

\subsubsection{Características do reator anaeróbio em batelada seqüencial}

O ASBR possui operação simplificada em quatro etapas: alimentação, reação, sedimentação e descarga. A primeira fase é a fase de alimentação, em que o reator é

\footnotetext{
${ }^{1}$ DAGUE, R. R.; McKINNEY, R. E.; PFEFFER, J. T. (1996). Anaerobic activated sludge. Journal Water Pollution Control Federation, v.38, n.2, p.220-6.

${ }^{2}$ SCHROEPFER, G. J.; FULLEN, W. J.; JOHNSON, A. S.; ZIEMKE, N. R.; ANDERSON, J. J. (1955). The anaerobic contact process as applied to packinghouse wastes. Sewage Ind. Wastes, v.27, n.4, p.460-86.
} 
alimentado com volume pré-determinado de água residuária orgânica. A segunda fase é a fase de reação, na qual o reator é misturado por período de tempo pré-determinado. No início da fase de reação, a alta concentração de substrato resulta em alta atividade metabólica, que promove remoção de substrato. O tempo necessário para que essa fase seja completada depende de vários parâmetros: composição do substrato, qualidade desejada do efluente, concentração da biomassa e temperatura do esgoto. A mistura permite aos microrganismos entrar em contato e estabilizar o substrato. De acordo com a cinética de Monod, a alta razão substrato/microrganismo (S/M), no início do ciclo de reação, causa alta produção de gás, a qual diminui com o decréscimo da concentração de alimento.

Quando são baixas a velocidade de produção de gás e a razão S/M, o reator está apto a iniciar a terceira fase, que é a sedimentação. A baixa razão $S / M$, durante a fase de sedimentação, permite aos sólidos sedimentarem rapidamente, pois a produção de gás é muito baixa, diferente do que ocorre para altas razões $\mathrm{S} / \mathrm{M}$ ou em reator de alimentação contínua, na qual a razão S/M é constante. Depois do período de sedimentação, tem início a quarta fase, com descarte do sobrenadante e permanência da manta de lodo no fundo do reator. Como os sólidos não são descartados, ocorre acúmulo e adensamento da biomassa no reator com conseqüente aumento do TRC e, portanto, é atingida a capacidade máxima de remoção de matéria orgânica. O reator é novamente alimentado, completando o processo cíclico. Condições alternadas de excesso e escassez de substrato, no ASBR, são as chaves para altas eficiências de conversão de substrato a metano, alta floculação e sedimentação da biomassa, sem necessidade de sedimentador externo (DAGUE et al., 1992; SUNG \& DAGUE, 1995; SCHMIT \& DAGUE, 1993).

Os processos anaeróbios de tratamento de água residuária operados de forma descontínua podem ser aplicados de maneira especialmente vantajosa nas seguintes situações ou condições: (1) em indústrias que intermitentemente produzem água residuária; (2) quando o padrão de emissão de efluentes for muito restritivo ou se a água residuária contiver composto orgânico recalcitrante; nesses casos, a descarga do efluente pode ser feita somente 
quando a qualidade for garantida, ou se o composto tóxico tiver degradação satisfatória; (3) em sistemas que visam reuso da água ou recuperação de compostos dissolvidos; e (4) em pesquisas fundamentais, a fim de elucidar alguns aspectos da degradação anaeróbia, devido às facilidades de instrumentação e de controle do processo.

Esses processos oferecem várias vantagens sobre outras tecnologias anaeróbias: (1) não ocorrem curtos-circuitos, como no caso de sistema contínuo de leito fixo; (2) permite melhor controle de qualidade do efluente; (3) não requer sedimentadores primários e secundários; (4) permite o controle adequado do processo; (5) apresenta alta eficiência na remoção de matéria orgânica; (6) processo de operação simples e estável.

Apesar dessas vantagens, esse tipo de reator é desprovido de metodologias e técnicas de operação pré-estabelecidas. Alguns dos problemas que afetam a eficiência do tratamento são: (1) ocorrência de zonas mortas, (2) alto tempo de sedimentação, (3) arraste de sólidos, (4) longo período de partida, (5) inibição devida à sobre carga orgânica e pouco conhecimento sobre agitação e estratégias de alimentação. A fim de se proverem bases racionais para projetos desses reatores, tais estudos voltam-se não apenas a aspectos tecnológicos, mas também a aspectos fundamentais, como transferência de massa, cinética e hidrodinâmica (ZAIAT et al., 2001).

\subsubsection{Estudos com reator anaeróbio em batelada seqüencial convencional}

Os estudos iniciais no ASBR utilizaram substratos, como leite em pó desnatado e efluente de suinocultura. Ocorreram altas remoções de demanda química de oxigênio (DQO), atingindo valores de até $80 \%$ para leite em pó desnatado; e com eficiência de até 92\% de remoção de sólidos suspensos voláteis (SSV), para efluente de suinocultura (DAGUE et al., 1992). 
SCHMIT \& DAGUE (1993) utilizaram o ASBR no tratamento de água residuária de suínos, às temperaturas de 20,25 e $35^{\circ} \mathrm{C}$. Concluíram que o reator foi capaz de remover de 40 a $60 \%$ de sólidos voláteis (SV), para cargas orgânicas expressas em DQO, de 0,9 a 5,0 g/L.dia, operando à temperatura de $20^{\circ} \mathrm{C}$. Esse resultado foi significativo, porque, em estudos anteriores nesse sistema, não haviam sido atingidas altas eficiências de remoção a essa temperatura. Com baixas cargas orgânicas, o reator apresentou bom desempenho e produziu efluente com pouco odor. A estabilidade do reator diminuiu com aumento da carga, o que indicou possível necessidade de tratamento adicional para altas cargas. De acordo com DROSTE \& MASSÉ (1995), o tratamento de esgoto de suinocultura em ASBR é estável e de simples operação. Os autores trabalharam com carga orgânica volumétrica de 1,6 g/L.dia, expressas como DQO, com remoção de $75 \%$ de sólidos voláteis, $80 \%$ de DQO solúvel e $60 \%$ de DQO total. O processo foi operado com sucesso em ciclos de 14 a 56 dias, com períodos de enchimento e de reação iguais, e temperatura de $20^{\circ} \mathrm{C}$. A biomassa pôde suportar concentrações de amônia de $3.000 \mathrm{mg} / \mathrm{L}$ ou mais. Padrões de alimentação de uma a três vezes por semana não influenciaram o desempenho do processo. Embora a mistura não fosse necessária, pois os tempos de ciclos eram elevados, experiências gerais com sistemas anaeróbios consideram ser prudente promover mistura nos sistemas em escala plena.

Em estudo sobre desempenho da digestão anaeróbia psicrofílica $\left(20^{\circ} \mathrm{C}\right)$ em ASBR, sob diferentes estratégias de operação, MASSÉ et al. (1996) obtiveram resultados experimentais na redução do potencial de poluição de efluente de suinocultura, com remoção de 84 a 93\% de DQO solúvel e 41 a $83 \%$ de DQO total, além da produção de metano acima de 0,48 L/g em relação aos sólidos voláteis e sucesso na redução de odores. Dessa forma, a digestão anaeróbia psicrofílica de efluente de suinocultura foi estável, com baixo consumo de energia e, segundo os autores, a maior parte da energia produzida poderia ser disponibilizada para o uso nas próprias fazendas.

MASSÉ et al. (1997) afirmaram que o ASBR é altamente adequado para tratamento de esgoto de suinocultura, em temperatura psicrofílica, porque oferece ótimas condições para 
reter alta concentração de microrganismos de lento crescimento no reator. Dessa forma, é possível suportar mudanças ambientais tais como variações de temperatura, mudanças na taxa de COV e presença de substâncias inibidoras.

ZHANG et al. (1997) estudaram o tratamento anaeróbio de esgoto de suinocultura em ASBR, à temperatura controlada de $25 \pm 1^{\circ} \mathrm{C}$ e mistura intermitente de 3 minutos a cada hora, por recirculação de gás no fundo do reator. Os autores concluíram que, para taxas de carga de sólidos voláteis entre 1,6 a 4,5 g/L.dia, foram alcançadas reduções de sólidos voláteis de 55 a $61 \%$.

ANGENENT et al. (2002a) estudaram os efeitos de diferentes inóculos para tratamento de esgoto de suinocultura em ASBR, em escala de bancada. Concluíram que a escolha do inóculo afetou o período de partida, mas não o rendimento de produção de metano. O reator com inóculo de lagoa anaeróbia atingiu o estado de equilíbrio dinâmico mais rapidamente que o reator com inóculo de digestor anaeróbio.

MASSE \& MASSE (2001) trataram água residuária de matadouro de porcos em ASBR. A redução da concentração de matéria orgânica foi superior a $90 \%$ independente da temperatura aplicada. Cargas orgânicas de 2,75, 2,94 e 4,93 kg/m ${ }^{3}$.dia foram aplicadas para temperaturas de 20,25 e $30^{\circ} \mathrm{C}$, respectivamente. Para essas cargas orgânicas, os sistemas foram eficientes e apresentaram estabilidade operacional, resultando em alta taxa de conversão de DQO a metano.

HOLLOPETER \& DAGUE (1994) conduziram pesquisa no tratamento de chorume de aterro sanitário municipal, usando ASBR, à temperatura constante de $35^{\circ} \mathrm{C}$. Chorume de aterro sanitário é geralmente bem adaptado para ser tratado anaerobiamente, devido à alta quantidade de ácidos graxos voláteis presentes. Entretanto, o chorume possui grande variação de composição, o que pode criar problemas na seleção e adequação do método de tratamento, que pode ou não ser bem sucedido, dependendo das características do chorume gerado. Os autores utilizaram sistema de tratamento de duas fases, ASBR e ASBR seguido 
de reator aeróbio, que serviu como unidade de polimento do efluente do reator anaeróbio. A COV aplicada, expressa em DQO, variou de 1,6 a 3,5 g/L.dia. Os resultados preliminares indicaram que o sistema composto por ASBR acoplado a uma unidade aeróbia de polimento, poderia ser desenvolvido para cada localidade, no tratamento localizado de chorume de aterros sanitários.

Nos estudos de TIMUR \& ÖZTURK (1999), relativos ao tratamento de chorume bruto no ASBR, obtiveram remoções de 64 a 85\%, para COV de 0,4 a 9,4 g/L.dia, expressas em DQO. Aproximadamente $83 \%$ da DQO removida foi convertida a metano.

O fenômeno da granulação em reatores anaeróbios em bateladas seqüenciais tratando glicose, foi estudado por WIRTZ \& DAGUE (1996, 1997). O objetivo foi buscar métodos de minimização do tempo requerido para a partida de processos anaeróbios. Foram testadas substâncias a fim de melhorar a granulação, como carvão ativado em pó, carvão ativado granular, sílica, polímeros e cloreto férrico. O polímero catiônico apresentou o melhor efeito benéfico na granulação, por reduzir o tempo necessário à formação de grânulos em aproximadamente 75\%, comparado ao ASBR sem adições. Os autores observaram a granulação da biomassa depois de, aproximadamente, 10 meses de operação, enquanto que no ASBR com adição de polímero catiônico, a granulação foi atingida com um mês de operação.

WELPER et al. (1997) estudaram, em laboratório, sistemas compostos por ASBR em série, operados a diferentes temperaturas, tratando substrato sintético à base de leite em pó desnatado. O sistema alcançou eficiências de remoção de 95 e 90\% para DQO solúvel e total, respectivamente, com COV, expressa em DQO, acima de 22 g/L.dia. O reator da primeira fase foi operado a $55^{\circ} \mathrm{C}$ e o da segunda fase a $35^{\circ} \mathrm{C}$. O tempo de ciclo foi de 18 horas (6 na fase I e 12 na fase II). Este sistema de duas fases incorporou vantagens dos processos termofílicos (altas velocidades de reação) e mesofílicos (efluente de melhor qualidade) e minimizou as desvantagens, como emissão de odores, comumente associados ao processo termofílico, e velocidades mais baixas do processo mesofílico. 
DUGBA \& ZHANG (1999) avaliaram o desempenho do sistema de dois estágios em reatores anaeróbios em bateladas sequienciais - operação termofílico versus mesofílico - no tratamento de água residuária de laticínios. A digestão anaeróbia em duas fases, com reatores operando a diferentes temperaturas, pode incorporar os processos termofílicos e mesofílicos em um único sistema, resultando, como benefícios, altas velocidades de digestão, eficácia na destruição de bactérias fecais, estabilidade do processo, sendo economicamente favorável para tratamento de águas residuárias de instalações de criação de animais. Os autores concluíram que sistemas ASBR, em dois estágios, são também adequados para tratar águas residuárias de laticínios com tempos de reação de 3 a 6 dias.

O tratamento anaeróbio de águas residuárias industriais diluídas foi estudado em três reatores anaeróbios em bateladas seqüenciais, em escala de laboratório, cada um com volume de $6 \mathrm{~L}$, à temperaturas psicrofílicas entre 5 e $25^{\circ} \mathrm{C}$ e tempos de ciclo de 6 a 24 horas. Utilizaram substrato sintético à base de leite em pó desnatado (DQO de $600 \mathrm{mg} / \mathrm{L}$ ) com suplementação de nutrientes e metais-traço. Obtiveram eficiência de remoção de DQO superior a $90 \%$ para temperaturas de 20 e $25^{\circ} \mathrm{C}$, em todos os tempos de ciclo. Para temperatura de $5^{\circ} \mathrm{C}$, e tempo de ciclo de 6 horas, a eficiência de remoção de DQO solúvel foi de $62 \%$. Para temperaturas intermediárias, entre 5 e $20^{\circ} \mathrm{C}$, e tempo de ciclo de 6 e 24 horas, a eficiência de remoção de matéria orgânica solúvel, expressa como DQO, esteve entre 62 e 90\%. A aplicação de ASBR no tratamento de águas residuárias a baixas temperaturas pode permitir redução dos custos do tratamento de esgotos municipais e industriais, em comparação com os processos aeróbios convencionais, que normalmente apresentam maior custo operacional, devido aos gastos com energia, com acondicionamento e disposição final do lodo (BANIK \& DAGUE, 1997; DAGUE et al., 1998).

BRITO et al. (1997) avaliaram o desempenho do reator no tratamento de águas residuárias de baixa carga, com concentração de, aproximadamente, $1.000 \mathrm{mg} / \mathrm{L}$, expressa como DQO, operado à temperatura de $22^{\circ} \mathrm{C}$. Para aumentar o contato sólido-líquido foi utilizado uma bomba de diafragma como unidade pulsadora, para recirculação de parte do 
efluente, a fim de evitar zonas mortas e possíveis resistências a transferência de massa externa. Atingiu eficiências de remoção de DQO de 60 a 70\%, após 5 e 6 horas de tempo de reação, para COV aplicada na faixa de 5 a $6 \mathrm{~kg} / \mathrm{m}^{3}$.dia, expressa como DQO.

Quatro reatores anaeróbios em bateladas seqüenciais, em escala de laboratório, foram usados por NDON \& DAGUE (1997a, 1997b) para tratar água residuária sintética, à base de leite em pó desnatado, com valores de DQO afluente de 400, 600, 800 e $1.000 \mathrm{mg} / \mathrm{L} \mathrm{e}$ temperaturas de $15,20,25$ e $35^{\circ} \mathrm{C}$. Os resultados do estudo mostraram eficiências de remoção de DQO solúvel de 80 a 90\% para várias concentrações e temperaturas. Esses resultados demonstraram a viabilidade do uso do ASBR no tratamento de águas residuárias de baixa carga, a baixas temperaturas.

O efeito da concentração inicial de inóculo na partida de ASBR foi estudado por De Los REYES III \& DAGUE (1995). O objetivo da pesquisa foi desenvolver protocolo de partida do ASBR e determinar a concentração ótima de biomassa no reator. Constataram que o desempenho do ASBR foi limitado pela retenção de sólidos no reator. Um protocolo efetivo de partida para o ASBR pode ser baseado no aumento progressivo de carga orgânica volumétrica. O reator inoculado com $15.000 \mathrm{mg} / \mathrm{L}$ de sólidos voláteis em suspensão pôde assimilar carga de 10 g/L.dia, em 28 dias, com eficiência de remoção de DQO solúvel de 90\%. A razão inicial de 0,5 de S/M permitiu partida rápida e estável. Entretanto, mesmo para altas razões de S/M, a eficiência de remoção de DQO solúvel permaneceu alta (90\%) e a concentração de ácidos voláteis baixa. Os autores concluíram que a utilização de inóculo em concentração elevada pode ocasionar arraste da biomassa e, portanto, que o tempo de sedimentação constitui parâmetro fundamental no controle da perda de sólidos, especialmente na forma suspensa de biomassa granular.

A fermentação anaeróbia da água residuária e a remoção de nutrientes em reatores em bateladas sequienciais foram estudadas por RODRÍGUEZ et al. (1998). Os autores estudaram a capacidade do sistema para remover nitrogênio e fósforo utilizando dois reatores, cada um com volume de $980 \mathrm{~L}$, como fermentador e lodo ativado. Usando ciclo de 
8 horas, os reatores foram operados e estudados durante 269 dias. Para os três valores de COV testada, expressa como DQO total por sólidos suspensos totais de 0,13, 0,25 e 0,35 $\mathrm{kg} / \mathrm{kg}$.dia foram alcançadas concentrações consistentes de $1,1 \mathrm{mg} / \mathrm{L}$ de fósforo e $38 \mathrm{mg} / \mathrm{L}$ de DQO efluente. A desnitrificação foi observada durante a fase de enchimento em todos os ciclos.

\subsubsection{Melhoramentos no Reator anaeróbio em batelada seqüencial}

De acordo com ZAIAT et al. (2001), os principais fatores que afetam o desempenho de reatores operados na forma descontínua são: intensidade de agitação, razão inicial entre substrato e concentração da biomassa (S/M), configuração geométrica do reator e estratégia de alimentação.

Os reatores anaeróbios operados de forma descontínua são agitados, principalmente, pela recirculação do gás gerado no processo anaeróbio. SUNG \& DAGUE (1995) recircularam biogás no reator por 2 e 5 minutos a cada hora e ZHANG et al. (1997) por 3 minutos a cada hora. DROSTE \& MASSÉ (1995) recircularam biogás por 20 minutos a cada hora e concluíram não ser necessária agitação. Os autores trabalharam com tempos de reação elevadíssimos, de 14 a 56 dias, o que impediu que a agitação causasse efeito significativo no sistema. HIRL \& IRVINE (1996) verificaram que agitação por recirculação de gás provocou evaporação de substâncias voláteis. De acordo com ANGENENT \& DAGUE (1995), em reatores sem imobilização de biomassa, a agitação intensa pode causar ruptura dos grânulos. Todavia, a agitação intermitente facilita a eficiência de separação gás-sólido, favorece a sedimentabilidade do lodo e melhora o desempenho do processo. Esses autores mencionaram que com alta agitação por reciclagem de gás houve a formação de espuma. BRITO et al. (1997) utilizaram bomba de diafragma como unidade de pulsação na recirculação do efluente, para aumentar o contato sólido-líquido e evitar zonas mortas e possíveis resistências à transferência de massa externa. 
Além de agitação por recirculação de gás ou líquido, os reatores descontínuos podem ser equipados com agitadores mecânicos. Isso favorece o contato da biomassa com o meio líquido e melhora as condições de transferência de massa no sistema. BORZANI et al. (1986) recomendam que os agitadores sejam escolhidos de modo tal que o líquido percorra determinados caminhos no reator.

Os agitadores podem ser classificados de acordo com o tipo de movimento que imprimem ao líquido. Dessa forma, existem agitadores que provocam escoamento axial, isto é, o líquido percorre caminho paralelo à direção do eixo do agitador; e agitadores que provocam escoamento tangencial ou radial, em que o fluido se desloca perpendicularmente à direção do eixo do agitador. Quanto à forma, de modo geral, os agitadores mecânicos podem ser classificados, como agitadores tipos hélice, palheta e turbina, como mostra a FIGURA 3.1.

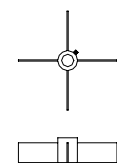

(a)

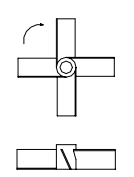

(b)

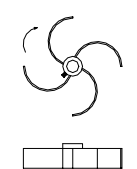

(c)

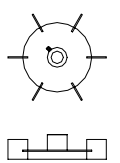

(d)

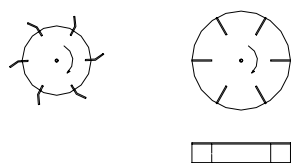

(e)

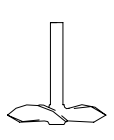

(g)

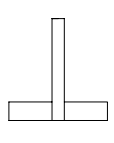

(h)

FIGURA 3.1 - Tipos de agitadores: (a) Turbina, lâminas planas verticais; (b) turbina, lâminas planas inclinadas; (c) turbina, lâminas curvas; (d) turbina, disco com lâminas planas; (e) turbina, disco com lâminas curvas; (f) turbina, ventoinha; (g) hélice e (h) palheta. Fonte: BORZANI et al., (1986).

No tanque agitado, a direção de escoamento do fluido depende do tipo de agitador, das características do fluido, do tipo de obstáculos existentes no tanque e das relações entre as dimensões dos componentes do reator, tais como: diâmetro do reator, diâmetro do agitador, forma e tamanho das chicanas (quando presentes). Pode-se dizer que, de modo geral, uma partícula de líquido, quando em agitação, está sujeita a três componentes de velocidade: uma longitudinal, que atua em direção paralela ao eixo de agitação; uma radial, que atua no plano perpendicular ao eixo e uma tangencial ou rotacional que atua tangencialmente ao percurso circular, em torno do eixo. O caminho percorrido pelo líquido, no tanque, é a resultante da variação dessas três componentes de velocidade. 
Para tratar chorume de aterro sanitário em ASBR, TIMUR \& ÖSTURK (1999) utilizaram barras magnéticas para promover agitação, com mistura intermitente de apenas 1 minuto a cada hora. Eles constataram que, mesmo com esse baixo tempo de agitação, o efluente não ficou completamente livre de sólidos suspensos e que aproximadamente $83 \%$ da DQO foi convertida a metano. DUGBA \& ZHANG (1999) obtiveram bons resultados no tratamento de água residuária de laticínios, operando sistema ASBR provido de misturador mecânico, sob condições termofílicas-mesofílicas, com tempo de reação de 3 e 6 dias e promovendo mistura de 1 minuto a cada hora.

RODRIGUES et al. (2003), ao estudarem as condições de agitação, perceberam que o melhoramento no fluxo de transferência de massa está ligado ao contato eficiente entre substrato e biomassa. Eles estudaram o efeito da velocidade de agitação no ASBR, inoculado com biomassa granulada para tratamento de água residuária sintética de baixa concentração. A agitação foi promovida por agitador mecânico tipo turbina, com seis pás planas verticais. À temperatura controlada a $30^{\circ} \mathrm{C}$ e para ciclos com duração de 8 horas, o reator apresentou boa eficiência quando submetido à agitação de $50 \mathrm{rpm}$. Os autores concluíram que a agitação aumentou a eficiência do reator e permitiu a redução do tempo total de ciclo.

SHIZAS \& BAGLEY (2002) estudaram os parâmetros operacionais do ASBR com o objetivo de melhorar o desempenho desse sistema. Diversos parâmetros foram variados e combinados. A glicose foi utilizada como substrato e a COV, aplicada na forma de DQO, variou de 2,1 a $3,2 \mathrm{~kg} / \mathrm{m}^{3}$.dia. Concluíram que a adoção de maior tempo de enchimento em relação ao tempo de ciclo e de menores concentrações iniciais de substrato possibilitaram melhores resultados na operação do reator.

A estratégia de alimentação em reatores anaeróbios seqüenciais em batelada, ou batelada alimentada, pode afetar significativamente seu desempenho, pois está diretamente relacionada à razão S/M aplicada e à retenção de sólidos (ZAIAT et al., 2001). De acordo com ANGENENT \& DAGUE (1995), para altas cargas, o tempo de alimentação pode ser aumentado, para obtenção de concentrações mais baixas de substrato no reator. Mudanças 
nas condições de operação, como tempo de alimentação mais longo e tempo de ciclo mais curto, podem melhorar o desempenho do processo ASBR. Isso resulta em decréscimo da concentração de ácidos voláteis, produtos intermediários da degradação anaeróbia.

\subsubsection{Reator anaeróbio em batelada seqüencial com biomassa imobilizada e agitação mecânica}

Diversos pesquisadores têm estudado formas de melhorar o desempenho do ASBR. Para controlar a perda de microrganismos na operação de descarga e aumentar o tempo de retenção celular, propuzeram utilização de biomassa imobilizada. HIRL \& IRVINE (1996) estudaram a descloração redutiva do percloetileno no reator anaeróbio em batelada seqüencial. Utilizaram seixos rolados lavados em ácido como material suporte e obtiveram bons resultados. RATUSZNEI et al. (2000) desenvolveram nova configuração do reator anaeróbio em batelada seqüencial para tratar água residuária sintética com baixa concentração, expressa como DQO. O reator, com volume de 2,5 L, continha biomassa imobilizada em matrizes de espuma de poliuretano. Foi operado à temperatura de $30^{\circ} \mathrm{C} \mathrm{e}$ velocidade de agitação de $500 \mathrm{rpm}$, fornecida por agitador magnético, junto ao fundo do reator. A duração do ciclo foi de 8 horas, sendo de $0,5 \mathrm{~L}$ o volume de substrato tratado por ciclo, com concentração média de $485 \mathrm{mg} / \mathrm{L}$, expressa como DQO. Esses estudos mostraram que a imobilização da biomassa melhorou a retenção de sólidos, eliminou a etapa de sedimentação e permitiu reduzir o tempo de operação. O período de partida (10 dias) foi curto com eficiência máxima na remoção de matéria orgânica solúvel, expressa como DQO, de $86 \%, 3$ horas após o início do ciclo.

RATUSZNEI et al. (2001) avaliaram a influência da velocidade de agitação magnética no desempenho do ASBR com biomassa imobilizada em espuma de poliuretano. Os resultados obtidos pela variação da intensidade de agitação de 0, 50, 100, 200, 350, 500 e $750 \mathrm{rpm}$ permitiram concluir que, em todas as condições experimentais investigadas, o sistema alcançou estabilidade em curto período de partida e alta retenção de sólidos, 
validando a configuração do reator proposto. Os autores concluíram que o aumento da agitação resultou em diminuição de resistência à transferência de massa e, conseqüentemente, em aumento do valor do parâmetro cinético.

Um sistema semelhante ao de RATUSZNEI et al. (2000, 2001) foi proposto por CUBAS et al. (2001). A principal diferença consistiu na agitação, promovida por agitador mecânico, com três impelidores, cuja velocidade do eixo variou de 300 a $1.100 \mathrm{rpm}$. A pesquisa foi proposta com o objetivo de avaliar a influência da transferência de massa na fase líquida, durante a operação do ASBR. O reator foi alimentado com substrato sintético que apresentava DQO média de $560 \pm 53 \mathrm{mg} / \mathrm{L}$, com duração dos ciclos de 8 horas. A eficiência média de remoção de DQO foi de $78 \pm 3 \%$. Os autores concluíram que os fenômenos de transferência de massa na fase líquida afetaram sensivelmente o desempenho total do reator e determinaram o tempo de ciclo requerido para fornecer máxima eficiência.

PINHO et al. (2002) avaliaram a influência da velocidade de agitação no tratamento de água residuária parcialmente solúvel. Utilizaram ASBR com volume de 5,5 L e biomassa imobilizada em matrizes cúbicas de espuma de poliuretano, com $3 \mathrm{~cm}$ de aresta e agitação mecânica promovida por impelidores tipo hélice, com $6 \mathrm{~cm}$ de diâmetro. Os ciclos foram de 8 horas, variaram a agitação de 500 a $1.100 \mathrm{rpm}$. Em 20 dias, o sistema entrou em equilíbrio dinâmico, com eficiência na remoção de substrato de 75\%, expresso como DQO. Os autores concluíram que a agitação promoveu boa mistura, melhorou a transferência de massa na fase líquida e influenciou positivamente a solubilização de particulados, o que provocou efeitos positivos nas velocidades de consumo da matéria orgânica.

Com o objetivo de estudar a transferência de massa na fase sólida, CUBAS et al. (2002) desenvolveram pesquisa no mesmo sistema utilizado por CUBAS et al. (2001), variando o tamanho das espumas de poliuretano de $0,5 \mathrm{a} 3,0 \mathrm{~cm}$. Os autores observaram que a concentração residual de matéria orgânica no efluente aumentou de acordo com o aumento da partícula. O tempo de ciclo não foi afetado para matrizes cúbicas de 0,5 a $2,0 \mathrm{~cm}$. 
Entretanto, para atingir o mesmo desempenho, o tempo de ciclo teve que ser aumentado para partículas com $3,0 \mathrm{~cm}$ de aresta. Os autores citam, como exemplo, que para alcançar eficiência de $90 \%$ de remoção de DQO, utilizando partículas de espuma com 3,0 cm de aresta é necessário aumentar o tempo de ciclo em $32 \%$ a mais do que se fossem utilizadas partículas de 0,5 a $2,0 \mathrm{~cm}$.

A possibilidade de operação do ASBR no tratamento de soro de queijo foi avaliada por RATUSZNEI et al. (2002) utilizando reator com volume total de 2,0 L. O reator foi operado em ciclos de 8 horas, sob agitação magnética de 200 rpm e à temperatura controlada à $30 \pm 1^{\circ} \mathrm{C}$. A DQO variou gradativamente, de um ensaio para outro, de 500 a $4.000 \mathrm{mg} / \mathrm{L}$. Concluíram que a estabilidade do reator foi muito dependente da estratégia de suplementação de alcalinidade, especialmente no período de partida. Além disso, o aumento da intensidade de agitação foi considerado indispensável, de maneira a permitir a homogeneização da fase líquida no reator, principalmente se forem aplicados maiores valores de carga orgânica volumétrica.

\subsubsection{Ampliação de escala do reator anaeróbio em batelada seqüencial}

SARTI et al. (2002) operaram ASBR em escala piloto com volume total de $1,2 \mathrm{~m}^{3} \mathrm{e}$ capacidade para tratamento de $0,65 \mathrm{~m}^{3}$, à temperatura ambiente, por 122 dias. Utilizaram biomassa imobilizada em espumas de poliuretano com $5 \mathrm{~cm}$ de aresta e agitação mecânica promovida por motor (240 watts - corrente contínua e $40 \mathrm{rpm}$ ) com redutor e eixo com 2 impelidores tipo turbina com 6 pás. O reator, após 20 dias, aproximadamente, atingiu o equilíbrio dinâmico, correspondentes a 60 ciclos seqüenciais de 8 horas cada. Os valores medidos da concentração média de matéria orgânica, expressa como DQO, foram $438 \pm 143$ $\mathrm{mg} / \mathrm{L}$ para esgoto afluente bruto, $180 \pm 72 \mathrm{mg} / \mathrm{L}$ para o efluente bruto e $126 \pm 53 \mathrm{mg} / \mathrm{L}$ para amostras do efluente filtrado. Os autores concluíram que esses resultados indicam que, após o curto período de partida, o reator atingiu estabilidade operacional, o que comprova a 
grande potencialidade de utilização dessa configuração de reator anaeróbio para o tratamento de esgotos sanitários.

ANGENENT et al. (2002b) operaram um ASBR, em escala real, com volume total de $600 \mathrm{~m}^{3}$ (15,0 $\mathrm{m}$ de diâmetro e altura de 3,4 m). Os autores utilizaram ciclos de 8 horas (0,2 horas - alimentação, 6,8 horas - reação, 0,5 horas - sedimentação e 0,5 hora - descarga) no tratamento de efluentes de suinocultura. O reator atingiu estabilidade operacional após 3 meses, o que indica viabilidade de seu uso no tratamento desse tipo de água residuária. $\mathrm{O}$ monitoramento da concentração de amônia total e ácidos voláteis, e a flexibilidade na operação do sistema, durante a partida, foram essenciais para o sucesso do ASBR.

\subsubsection{Comparação ASBR e UASB}

Uma Comparação entre os reatores UASB e ASBR foi proposta por ANGENENT \& DAGUE (1995) e está apresentada na TABELA 3.1. Ao ASBR contendo biomassa granulada são atribuídas semelhanças com o reator UASB nos seguintes aspectos: a biomassa formada apresenta boas características de sedimentação e desenvolvimento de lodo denso ou granular. A presença de lodo denso, no reator, significa menor perda de sólidos biológicos com o efluente, durante a operação de esvaziamento. Ademais, na prática, esse reator pode simular as características ideais do reator contínuo com escoamento pistonado, o que, em termos cinéticos, pode representar vantagem para eficiência de tratamento. Quanto à estabilização da matéria orgânica, ambos os reatores - UASB e ASBR - apresentam alta eficiência de remoção de DQO solúvel, com mais de 90\% de remoção para COV 19 de g/L.dia, expressa como DQO, após 3 meses de operação. 
TABELA 3.1 - Comparação entre sistema UASB e ASBR.

\begin{tabular}{|c|c|}
\hline UASB & ASBR \\
\hline $\begin{array}{l}\text { O reator funciona com manta de lodo e fluxo } \\
\text { ascendente } \\
\text { Alimentação contínua }\end{array}$ & $\begin{array}{l}\text { O reator possui quatro sequiências de operação: } \\
\text { alimentação, reação, sedimentação e decantação } \\
\text { Alimentação intermitente, resultando em condições } \\
\text { de alta e baixa concentração de substrato }\end{array}$ \\
\hline Pode necessitar recirculação & Não é necessária a recirculação \\
\hline Apresenta riscos de curtos circuitos & Não há curtos circuitos, mas pode haver zonas mortas \\
\hline Não necessita de mistura para granulação & $\begin{array}{l}\text { Necessita mistura para granulação através de mistura } \\
\text { mecânica, hidráulica ou por recirculação de gás }\end{array}$ \\
\hline $\begin{array}{l}\text { Necessita sistema separador de gás-sólido para separar } \\
\text { a biomassa do efluente }\end{array}$ & $\begin{array}{l}\text { Necessita sistema de deslocamento de gás para } \\
\text { permitir a alimentação e decantação intermitente }\end{array}$ \\
\hline $\begin{array}{l}\text { É mais aplicado a águas residuárias de baixa } \\
\text { concentração de sólidos suspensos }\end{array}$ & $\begin{array}{l}\text { Aplicação para tratamento de águas residuárias com } \\
\text { baixa e alta concentração de sólidos em suspensão }\end{array}$ \\
\hline $\begin{array}{l}\text { Dependência, entre outros, da velocidade ascendente do } \\
\text { substrato no reator para o fenômeno da granulação }\end{array}$ & $\begin{array}{l}\text { O fenômeno da granulação não depende da } \\
\text { velocidade ascendente do substrato no reator }\end{array}$ \\
\hline $\begin{array}{l}\text { Normalmente não requer suporte inerte para adesão de } \\
\text { microrganismos }\end{array}$ & \\
\hline $\begin{array}{l}\text { Necessita de boa distribuição de substrato para a } \\
\text { obtenção de mais pontos de entrada no fundo do reator }\end{array}$ & \\
\hline
\end{tabular}

Fonte: ANGENENT \& DAGUE (1995).

\subsubsection{Cinética microbiana no reator anaeróbio em batelada sequiencial}

MASSÉ \& DROSTE (1997) desenvolveram modelo dinâmico, baseado em esquema simplificado, para digestão anaeróbia psicrofílica de esgoto de suinocultura em reator em batelada seqüencial. Considerada a complexidade total desse processo, o modelo foi julgado aceitável para predizer a acumulação de DQO solúvel e as vazões de metano. Foram obtidas constantes cinéticas de primeira ordem para cada série de experimento, conforme valores expressos na TABELA 3.2. O modelo é um útil instrumento para estudo da influência das estratégias de operação do ASBR nas iterações dinâmicas entre formadoras de ácido e metano.

TABELA 3.2 - Parâmetros cinéticos obtidos para faixa de dados estudados.

\begin{tabular}{lcccc}
\hline Constante & Unidade & Acidogênese & Metanogênese & $\begin{array}{c}\text { Valor } \\
\text { incremental }\end{array}$ \\
\hline $\mathrm{V}_{\max . \mathrm{i}}{ }^{(\mathrm{a})}$ & $\mathrm{mg} / \mathrm{mg} \cdot \mathrm{dia}$ & $0,04-0,80$ & $0,04-1,4$ & 0,01 \\
$\mathrm{~K}_{\mathrm{S}}^{\left({ }^{(b)}\right.}$ & $\mathrm{mg} / \mathrm{L}$ & $100-2.500$ & $50-3.000$ & 10,0 \\
$\mathrm{Y}_{\mathrm{i}}{ }^{(\mathrm{c})}$ & $\mathrm{mg} / \mathrm{mg}$ & $0,05-0,25$ & $0,01-0,20$ & 0,01 \\
$\mathrm{k}_{\mathrm{di}}{ }^{(\mathrm{d})}$ & $\mathrm{dia}^{-1}$ & $0,0005-0,04$ & $0,0005-0,04$ & 0,0001 \\
$\mathrm{~K}_{\mathrm{p}}{ }^{(\mathrm{e})}$ & $\mathrm{dia}^{-1}$ & $0,01-0,08$ & $0,01-0,08$ & 0,005 \\
\hline${ }^{(a)}$ Velocidade específica máxima de DQO solúvel, ${ }^{(b)}$ coeficiente de \\
meia-velocidade de saturação, ${ }^{(c)}$ fator de rendimento, ${ }^{\left({ }^{d}\right)}$ constante de \\
morte celular e e ${ }^{(e)}$ velocidade específica de solubilização de primeira \\
ordem. \\
Fonte: MASSÉ \& DROSTE (1997).
\end{tabular}


BANIK \& DAGUE (1997) e DAGUE et al. (1998), citados anteriormente, obtiveram parâmetros cinéticos de primeira ordem, conforme apresentados na TABELA 3.3. Foi encontrado coeficiente de correção da temperatura 1,08 , para variações de 7,5 a $25^{\circ} \mathrm{C}$, da expressão de Van't Hoff.

TABELA 3.3 - Parâmetros cinéticos medidos para várias temperaturas.

\begin{tabular}{ccccccccc}
\hline \multirow{2}{*}{ Parâmetros } & \multirow{2}{*}{ Unidade } & \multicolumn{7}{c}{ Temperatura $\left({ }^{\circ} \mathrm{C}\right)$} \\
\cline { 3 - 9 } & & 7,5 & 10 & 12,5 & 15 & 17,5 & 20 & 25 \\
\hline $\mathrm{k}_{\max }{ }^{(a)}$ & $\mathrm{dia}^{-1}$ & 0,42 & 0,53 & 0,69 & 1,06 & 1,12 & 1,14 & 1,59 \\
$\mathrm{~K}_{\mathrm{S}}^{(\mathrm{b})}$ & $\mathrm{mg} / \mathrm{L}$ & 424 & 477 & 395 & 534 & 449 & 259 & 219 \\
$\mathrm{R}^{2(\mathrm{c})}$ & $*$ & 0,71 & 0,70 & 0,68 & 0,92 & 0,85 & 0,90 & 0,95 \\
\hline
\end{tabular}

(a) velocidade específica máxima de remoção de substrato, ${ }^{(b)}$ coeficiente de meiavelocidade de saturação $e^{(c)}$ coeficiente de correlação.

Fonte: Adaptado de BANIK \& DAGUE (1997) e DAGUE et al. (1998).

BAGLEY \& BRODKORB (1999) propuseram um modelo cinético microbiano para o reator anaeróbio em batelada sequiencial, no tratamento de glicose. Os resultados experimentais e de simulação indicaram que, para a mesma carga orgânica, o desempenho do reator melhorou com tempo de enchimento mais lento. $\mathrm{O}$ modelo pode ser usado para rapidamente identificar outras oportunidades para a melhoria da capacidade do ASBR em tratar uma variedade de tipos de águas residuárias, nas condições estudadas.

RATUSZNEI et al. (2001) obtiveram modelo cinético de primeira ordem que representou adequadamente a degradação do substrato no reator ASBR. Os parâmetros $\mathrm{k}_{1}{ }^{\mathrm{ap}} \mathrm{e}$ $\mathrm{C}_{\mathrm{SR}}$ estão apresentados na TABELA 3.4 e foram obtidos através da eq. (1).

$R_{S}=-\frac{d C_{S}}{d t}=k_{1}^{a p}\left(C_{S}-C_{S R}\right)$

$\mathrm{Na}$ equação $\mathrm{R}_{\mathrm{S}}$ é a velocidade de consumo de substrato, $\mathrm{C}_{\mathrm{S}}$ a concentração de substrato, $\mathrm{C}_{\mathrm{SR}}$ a concentração de substrato residual, $\mathrm{k}_{1}{ }^{\text {ap }} \mathrm{o}$ coeficiente cinético aparente de primeira ordem e t o tempo.

Os parâmetros desse modelo modificado foram determinados através do método diferencial pela estimação das velocidades de reações experimentais por Le Duy e Zajic. O 
parâmetro $\mathrm{C}_{\mathrm{SR}}$ não faz parte do modelo de primeira ordem comum. Dessa forma, esse parâmetro funciona como "normalizador" do modelo, já que a velocidade de reação atinge valores nulos para concentrações diferentes de zero.

TABELA 3.4 - Parâmetros cinéticos de primeira ordem obtidos para diferentes velocidades de agitação magnética.

\begin{tabular}{|c|c|c|c|c|c|c|c|c|}
\hline \multirow{2}{*}{ Parâmetros } & \multirow{2}{*}{ Unidade } & \multicolumn{7}{|c|}{ Velocidade de agitação (rpm) } \\
\hline & & 0 & 50 & 100 & 200 & 350 & 500 & 750 \\
\hline $\mathrm{k}_{1}^{\text {ap (a) }}$ & $\operatorname{dia}^{-1}$ & 1,44 & 0,78 & 1,05 & 1,14 & 1,36 & 1,31 & 1,70 \\
\hline $\mathrm{C}_{\mathrm{SR}}^{(\mathrm{b})}$ & $\mathrm{mg} / \mathrm{L}$ & 108 & 60 & 70 & 70 & 50 & 38 & 49 \\
\hline $\mathrm{R}^{2(\mathrm{c})}$ & $*$ & 0,956 & 0,972 & 0,984 & 0,960 & 0,966 & 0,932 & 0,987 \\
\hline
\end{tabular}

Nos estudos de CUBAS et al. (2002) foram obtidos coeficientes cinéticos aparentes de primeira ordem $\left(\mathrm{k}_{1}{ }^{\mathrm{ap}}\right)$, para transferência de massa na fase sólida, sendo $0,59 \pm 0,01 \mathrm{~h}^{-1}$ para partículas de espuma de poliuretano de $3,0 \mathrm{~cm} \mathrm{e} 0,48 \mathrm{~h}^{-1}$ para partículas de 0,5 a 2,0 cm. PINHO et al. (2002) obtiveram parâmetros cinéticos aparentes de primeira ordem para diferentes velocidades de agitação mecânica, como mostrados na TABELA 3.5. RODRIGUES et al. (2003) estudaram as condições de agitação de ASBR com biomassa granulação e, após compilação dos dados, observaram que para remoção de matéria orgânica o desempenho do reator seguiu modelo cinético de primeira ordem.

TABELA 3.5 - Parâmetros cinéticos de primeira ordem obtidos para diferentes velocidades de agitação mecânica

\begin{tabular}{ccccccc}
\hline $\begin{array}{c}\text { Velocidade } \\
\begin{array}{c}\text { Agitação } \\
(\mathrm{rpm})\end{array}\end{array}$ & Total & Suspenso & Filtrado & Total & Suspenso & Filtrado \\
\cline { 2 - 7 }$\left(\mathrm{h}^{-1}\right)$ & $\mathrm{C}_{\mathrm{SR}}{ }^{(\mathrm{b})}$ \\
& $\mathrm{mg} / \mathrm{L})^{*}$ & \\
700 & $0,91 \pm 0,05$ & $0,88+0,12$ & $0,93+0,08$ & 179 & 86 & 93 \\
700 & $1,22+0,06$ & $1,30+0,09$ & $1,16+0,06$ & 143 & 45 & 98 \\
900 & $1,90+0,17$ & $3,98+0,21$ & $0,85+0,08$ & 108 & 42 & 66 \\
1.100 & $1,18+0,02$ & $1,72+0,11$ & $0,84+0,03$ & 86 & 42 & 44 \\
\hline
\end{tabular}

* Experimental (média da concentração afluente, expressa como DQO, igual a $974 \pm 70$ $\mathrm{mg} / \mathrm{L}),{ }^{(a)}$ coeficiente cinético aparente de primeira ordem $e^{(b)}$ concentração residual calculada em termos de DQO.

Fonte: PINHO et al. (2002). 


\subsection{Reatores anaeróbios com biomassa imobilizada em materiais suportes inertes}

Uma das maiores preocupações no projeto de reatores anaeróbios para tratamento de águas residuárias é a escolha do método mais apropriado para imobilização da biomassa. A maior vantagem da biotecnologia anaeróbia - baixo fator de conversão entre susbtrato e biomassa - é também sua principal desvantagem quando se busca aumentar a concentração de biomassa no reator. A retenção eficiente da biomassa é indispensável para manutenção do vagaroso crescimento microbiano. Deve ser alcançada alta razão de TRC/TDH para que o tratamento anaeróbio de águas residuárias diluídas se torne economicamente atrativo do ponto de vista econômico (SPEECE, 1996).

Os suportes inertes são mais freqüentemente usados para a aderência microbiana. Uma grande variedade de suportes como areia, brita, cerâmicas, bambu, silicatos minerais, óxidos metálicos, entre outros, são utilizados como suportes para aderência microbiana. No caso de reatores de leito fluidificado/expandido, utiliza-se areia, carvão granular ativado, grãos de material sintético, esponjas, etc. A capacidade de aderência de tais suportes tem papel importante no início da colonização microbiana; passada essa primeira fase, tal característica tem sua importância diminuída (CAMPOS, 1994).

PASSIG (1997) operou filtro anaeróbio de fluxo ascendente que continha material suporte em PVC, como alternativa à brita $\mathrm{n}^{\mathrm{o}} 4$, comumente usada nesses tipos de reatores. $\mathrm{O}$ reator foi alimentado com substrato sintético, com composição similar ao esgoto sanitário. O PVC apresentou-se como boa alternativa para a aderência de microrganismos, tendo alcançado eficiência média de $82 \pm 7 \%$ para COV média, expressa como DQO, de 0,48 $\mathrm{kg} / \mathrm{m}^{3}$.dia e $86 \pm 7 \%$ para COV média de $0,75 \mathrm{~kg} / \mathrm{m}^{3}$.dia.

VALLERO et al. (2000) avaliaram a atividade biológica das células livres e imobilizadas formadas em um filtro anaeróbio, em escala de bancada. A imobilização da biomassa, em um mesmo reator, ocorreu em quatro suportes inertes diferentes, alocados de 
maneira eqüitativa. São eles: material cerâmico de baixa porosidade (cerâmica refratária), material cerâmico de alta porosidade (especial para retenção), material polimérico de baixa porosidade (PVC) e material polimérico de alta porosidade (espuma). Os autores utilizaram esgoto sintético, com composição similar ao esgoto sanitário e, como inóculo, lodo de UASB de indústria de papel, com TDH de 24 horas e temperatura de $30^{\circ} \mathrm{C}$. O reator apresentou eficiência média de DQO de 57\%. Em suas conclusões, os autores destacaram que, a porosidade teve importância crucial no que se refere à capacidade de retenção de biomassa. Os quatros suportes inertes utilizados apresentaram maior porosidade na seguinte ordem: espuma $>$ cerâmica especial $>$ tijolo refratário $>$ PVC. A retenção da biomassa na espuma foi 2,0 vezes maior que a alcançada pela cerâmica especial, 2,9 vezes maior que a obtida com tijolo refratário e 3,6 vezes maior que a do PVC.

MENDONÇA (1999) estudou a caracterização do material suporte e a partida de reator anaeróbio de leito expandido de $32 \mathrm{~m}^{3}$, para tratar esgoto sanitário. Foram estudadas partículas de poliamida, polibutireno teretraftalato e carvão ativado granular; este último foi o mais adequado para compor o leito do reator, por ter apresentado melhor capacidade para aderência de microrganismos, bem como menor arraste do leito sob velocidades ascensionais elevadas. A partir do $202^{\circ}$ dia de operação, com DQO média afluente de $738 \mathrm{mg} / \mathrm{L}$, a qualidade do efluente produzido pelo reator apresentou valor médio de $207 \mathrm{mg} / \mathrm{L}$ de DQO, que corresponde a eficiência média de $72 \%$, considerados satisfatórios neste estudo.

SILVA et al. (2002) avaliaram quatro materiais suportes para imobilização de bactérias redutoras de sulfato e arqueas metanogênicas. Os suportes escolhidos foram espuma de poliuretano, carvão vegetal, polietileno de baixa densidade e cerâmica de alumina. A espuma de poliuretano apresentou maior concentração de biomassa, expressa como sólidos voláteis por grama de suporte, igual a $872 \mathrm{mg} / \mathrm{mg}$, enquanto os outros obtiveram valores de, no máximo, $84 \mathrm{mg} / \mathrm{mg}$. Para a espuma de poliuretano e o carvão vegetal, foram obtidas eficiências na redução de sulfato de $39 \%$ e $45 \%$ e eficiência média de remoção de matéria orgânica de $86 \%$ e $90 \%$, respectivamente. 


\subsection{Pedra pome utilizada como material suporte}

Existe, no mercado, pedra pome natural e sintética. A pedra pome natural tem origem vulcânica. O Brasil não possui jazida desse material e o importa da Itália. A pedra pome é um abrasivo natural, utilizada em numerosas aplicações, como metalúrgicas, curtumes, filtros, borrachas, vidros, etc. São vendidas em diversas granulometrias, como em pedra, em grânulos e em pó, em sacos de $50 \mathrm{~kg}$. O preço praticado no mercado é muito alto, o que levou à escolha da pedra pome sintética fabricada e utilizada no Brasil. Seu custo é muito menor, da ordem de $\mathrm{R} \$ 80,00 / \mathrm{m}^{3}$ (outubro/2002). No entanto, a pedra pome sintética possui exatamente o mesmo sistema de produção do concreto celular autoclavado, inicialmente produzido na Suécia, em 1924.

O concreto celular autoclavado possui diversos usos no mercado, principalmente na construção civil, utilizado como abrasivo e em lugares que necessitam estrutura leve, devido à sua alta porosidade. Além de ser vendido como pedra pome, os usos mais comuns desse material são em parede portante, painel armado, laje, vedação, isolamento térmico/acústico, enchimento e escultura artística.

Foram efetuados contatos com a empresa fabricante da pedra pome sintética, que utiliza para tal areia, cimento, cal e alumínio. As quantidades de cada material não foram reveladas; porém, a composição segue uma proporção piramidal, conforme mostra a FIGURA 3.2.

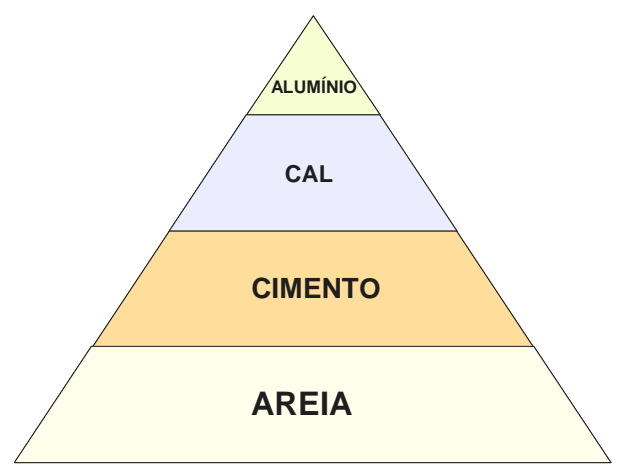

FIGURA 3.2 - Pirâmide da composição da pedra pome sintética. 
O processo completo de produção leva em torno de 10 horas e encontra-se esquematizado na FIGURA 3.3. A areia, com $85 \%$ de sílica, é transportada para britador de mandíbula e passa por peneira de correia, com malha 3/4”. Em seguida, é transportada para os silos de estoque. Uma parte vai para o moinho, onde é transformada em lama. Em outro silo, são acrescentados cimento Portland, cal virgem e alumínio em pó, em quantidades prédeterminadas. O alumínio funciona como agente expansor. A massa é homogeneizada e, a partir de 5 minutos, o alumínio da inicio ao processo de reação, liberando calor e formando os poros. Após homogeneização, o material permanece em repouso por aproximadamente 2 horas, para hidratação. Logo após, é iniciado o corte dos blocos, com 3 m x 1,5 m x 66 cm. Esses blocos passam pela autoclave saturada de vapor, a aproximadamente $220^{\circ} \mathrm{C}$, pressurizado sob pressão constante. Por fim, prontos para comercialização, os blocos vão para o galpão de estoque, após serem cortados de acordo com a necessidade do cliente.

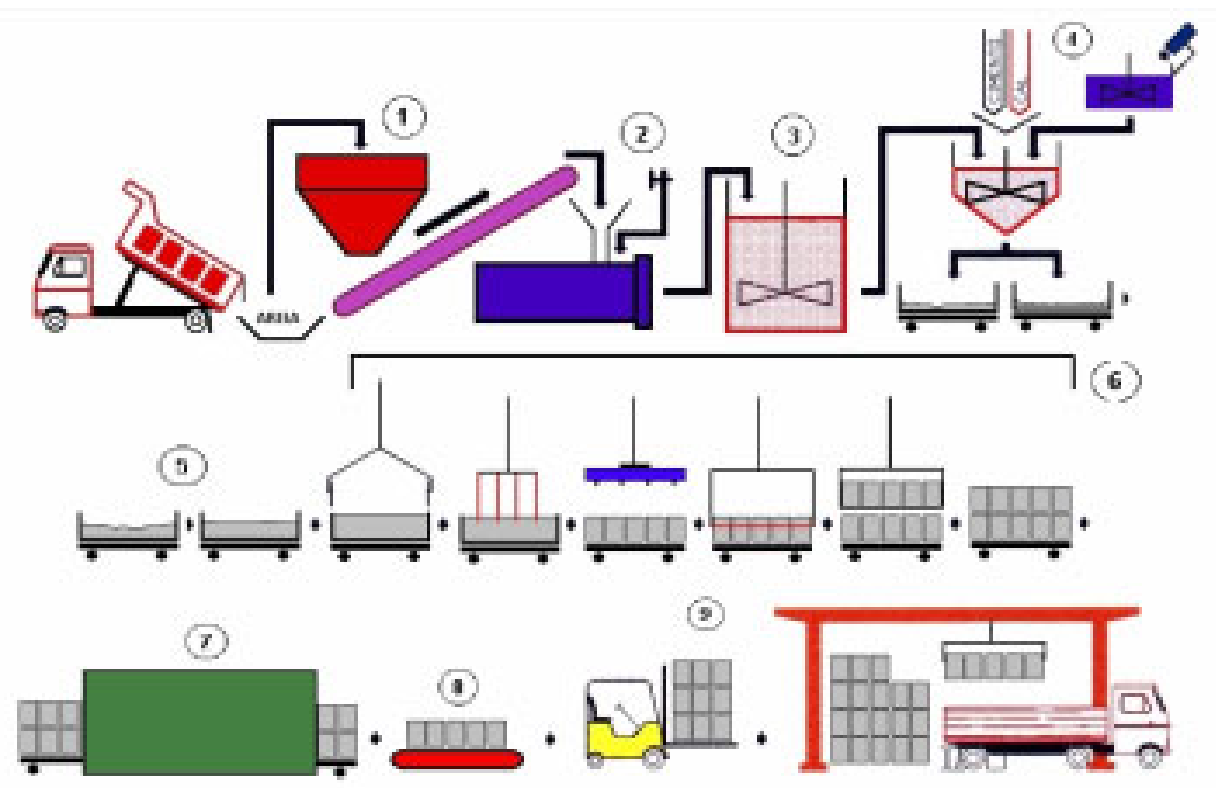

FIGURA 3.3 - Esquema de produção do concreto celular autoclavado - pedra pome sintética. (1) britador de mandíbula; (2) moinho de bolas; (3) silo com lama quartizoza; (4) silo de dosagem dos compostos; (5) processo de hidratação e formação de poros; (6) corte dos blocos; (7) autoclave; (8) bloco proto para o comércio e (9) estocagem. 
O comportamento e propriedades de materiais porosos, naturais ou artificiais, são fortemente afetados pela presença de vazios. Eles podem ser classificados sob vários aspectos, como finalidades de utilização, origem natural ou artificial, características quanto a porosidade, forma, tamanho e interconexão do poros. A pedra pome natural, encontrada em regiões vulcânicas, é bastante usada como abrasivo. Esses materiais são resultantes de gases contidos dentro da massa fundida, os quais, por conseqüência da redução de pressão, formam os poros (BEVILACQUA \& FERRARA, 1996).

HARENDRANATH et al. (1996), com o objetivo de construir base de dados para seleção de materiais suportes, para imobilização de biomassa em reatores de filme fixo, estudaram 24 materiais suporte, entre eles a pedra pome natural. Classificaram os materiais em lisos, irregulares e porosos. Dentre os fatores analisados para todos os suportes a pedra pome revelou as seguintes características: (1) estrutura altamente porosa, (2) composta por unidades cristalinas de 2 a $5 \mu$ de comprimento, (3) presença de poros profundos densamente distribuídos com $10 \mu$ de profundidade, (4) presença de macroestrutura de vários tamanhos e formatos, (5) porosidade igual a 0,49, (6) área superficial específica de 5.000 a 10.000 $\mathrm{m}^{2} / \mathrm{m}^{3}$. A pedra calcária e a pedra pome, observadas em microscopia eletrônica de varredura, revelaram estrutura cristalina. Os autores concluíram que elas podem ser utilizadas como meio suporte devido à alta porosidade e estrutura cristalina, resultando em alta área superficial.

A pedra pome foi utilizada como suporte para o dióxido de titânio $\left(\mathrm{TiO}_{2}\right)$ empregado na fotocatálise por RACHEL et al. (2002). A fotocatálise frequientemente é proposta para eliminar poluentes orgânicos biorecalcitrantes de águas residuárias. A pedra pome mostrouse promissora devido à sua alta porosidade e por apresentar $\mathrm{pH}$ neutro. Os autores utilizaram pedra pome proveniente de duas empresas francesas, mas não ficou claro se era pedra pome artificial ou natural. Os resultados obtidos mostraram que a pedra pome foi um suporte 
poroso promissor para imobilização do $\mathrm{TiO}_{2}$, por permitir obter boa retenção e eficiência na fotocatálise do 3-nitrobenzenosulfônico e 4-nitrotolueno-2-sulfônico.

DICTOR et al. (1997) utilizaram diferentes suportes para tratamento biológico de água residuária de cianidação de minas de ouro em reatores aeróbios de leito fixo. Os materiais utilizados foram carvão ativado, pozzolana e mistura de pedra pome e zeolita. Utilizaram pedra pome de origem vulcânica, procedente de Göre na Turquia. Foram realizados testes de adsorção para cianeto nas formas de tiocianeto, cianeto total e cianeto livre e os resultados demonstraram que os suportes pozzolana, zeolita e pedra pome não adsorvem qualquer das formas de cianeto, enquanto o carvão ativado adsorve todas as formas do cianeto. Os resultados indicaram que a remoção do cianeto ocorreu por processos biológicos. Os autores concluíram, após seis meses de operação, que todos os suportes permitiram fixação de bactérias e mais de $90 \%$ do tiocianeto foi biologicamente decomposto em $\mathrm{NH}_{4}{ }^{+}, \mathrm{CO}_{2} \mathrm{e} \mathrm{SO}_{4}{ }^{-2}$, mesmo quando as concentrações de poluentes foram aumentadas.

PATEL et al. (1999) utilizaram pedra pome com arestas de $5 \mathrm{~mm}$ como um dos materiais suporte estudados no tratamento de soro de queijo, em reator anaeróbio de filme fixo e fluxo ascendente. Utilizaram reator de $1 \mathrm{~L}$, à temperatura de $40^{\circ} \mathrm{C}$, com $\mathrm{TDH}$ de 2 dias. A concentração afluente, expressa como DQO, foi de $30 \mathrm{~g} / \mathrm{L}$ e a eficiência de remoção foi de $68 \%$.

BALAGUER et al. (1991) avaliaram o potencial de uso da pedra pome natural no tratamento de água residuária de destilaria de vinho, em reator anaeróbio de leito fluidizado. Utilizaram um reator com volume de $0,63 \mathrm{~L}$, operado à temperatura controlada em $35^{\circ} \mathrm{C}$, com $200 \mathrm{~mL}$ de pedra pome $\left(0,53 \mathrm{~mm}\right.$ de diâmetro e $1.526,4 \mathrm{~kg} / \mathrm{m}^{3}$ de densidade). Para os valores de TDH de 0,5 a 2,24 dias, a eficiência de remoção de matéria orgânica foi de 76,5 a 94,1\% e a vazão específica de produção de gás foi de 0,28 a $12,31 \mathrm{~m}^{3} / \mathrm{m}^{3}$.dia. MURRAY ${ }^{3}$ et

\footnotetext{
${ }^{3}$ MURRAY, W. D. \& VAN DEN BERG, L. (1981) Effect of support materials on the development of microbial fixed films converting acetic acid to methane. Journal Applied Bacterial, v.51, p.305-8.
} 
al. (1981) apud HARENDRANATH et al. (1996) constataram que o acúmulo microbiano é otimizado quando o diâmetro do poro é 1 a 5 vezes maior que a dimensão do microrganismo.

\subsection{Formação de biofilmes}

De acordo com COSTERTON et al. (1995), biofilmes são populações microbianas, presas à matrizes de polissacarídeos, nas quais os microrganismos podem aderir-se uns aos outros ou em superfícies e interfaces. Essa definição inclui agregados microbianos granulados e floculentos, assim como populações aderidas à superfícies porosas. BROCK et al. (1995) define biofilme como microcolônia de populações microbianas aderidas a uma superfície por meio de polissacarídeos excretados pelas células. BRYERS (1988) afirma que qualquer superfície que apresente atividade microbiana pode ser conceitualmente denominada biofilme.

A imobilização de células em superfícies sólidas é um fenômeno da natureza. Este fenômeno natural tem importantes implicações na erosão do solo, corrosão metálica e poluição da água. Diversos autores já comprovaram a existência de filmes microbianos em vários ambientes naturais, inclusive folhas e raízes de vegetais e, até mesmo, como placa bacteriana dental em humanos (VIJAYALAKSHIMI et al., 1990).

A imobilização celular pode ser definida como qualquer técnica que limite o livre movimento das células. Pode, também, ser considerada como técnica que impede que células ativadas em reator sejam carreadas com a fase móvel, que transporta o substrato e o produto. A mobilidade celular pode ser restringida por agregação própria, confinamento ou aderência a meio suporte inerte (WANG \& YANG, 1990).

$\mathrm{Na}$ forma de biomassa aderida a suportes inertes, os biofilmes têm sido estudados e utilizados em reatores biológicos, incluindo indústrias de alimentos, cervejas, farmacêuticas, químicas, combustíveis e para tratamento de águas residuárias de diversas composições. O processo anaeróbio beneficiou-se dessa tecnologia, pois reatores com biofilme fixo têm 
obtido bom desempenho, com grande estabilidade, uma vez que esses reatores são os que propiciam maiores razões entre tempo de retenção celular e tempo de detenção hidráulica (TRC/TDH).

As condições favoráveis para manutenção de altas concentrações de biomassa, no interior de reatores, segundo SPEECE (1996) são: (a) superfícies fixas e rugosas para facilitar o desenvolvimento de biofilme; (b) projeto apropriado para otimizar as características de sedimentação dos consórcios microbianos; (c) provisões nutricionais adequadas para desenvolver grânulos que apresentem alta velocidade de sedimentação; e (d) condições de quiescência nas zonas de entrada e de saída, de forma a maximizarem desenvolvimento de grande densidade de agregados microbianos.

A instalação, formação e resistência do biofilme são resultados de vários processos, como: (a) processos de deposição, responsável pelo acondicionamento da superfície, transporte celular e aderência; (b) processos metabólicos, que resultam no consumo de substrato, no crescimento e na reprodução celular, bem como na sustentação e produção de polímeros extracelulares; e (c) processos de remoção, ou seja, perda contínua da camada externa do biofilme e por outros organismos (BRYERS, 1988).

Estudos de COSTERTON et al. (1995) revelaram que os biofilmes microbianos são caracterizados, em parte, pela produção de extensa rede de exopolissacarídeos altamente hidratados. O polímero extracelular excretado pelo biofilme apresenta alta heterogeneidade espacial, relacionada à sua composição química e suas propriedades físicas. Os polímeros extracelulares (PEC) são produzidos por microrganismos constituintes do biofilme e apresentam funções, por exemplo, na aderência inicial dos microrganismos à superfícies, formação e manutenção da microcolônia. Em condições ambientais desfavoráveis, atuam na proteção do biofilme contra ação predatória de protozoários. Além disso, servem como reserva de substrato para o próprio biofilme.

A colonização microbiana da interface sólido-líquido deve ocorrer, segundo Van LOOSDRECHT et al. (1990), em quatro etapas. Primeiramente, na fase de transporte, os 
microrganismos podem atingir a superfície por difusão, convecção ou transporte ativo. $\mathrm{Na}$ etapa seguinte, a aderência inicial, pode ser reversível (devido ao movimento Browniano) ou irreversível. Após a colonização, ocorre a terceira etapa, de fixação à superfície. Estruturas especiais da membrana celular (fibrilas ou polímeros) que formam fortes ligações entre a membrana e a superfície do sólido, fixam o microrganismo. Por fim, a quarta etapa, a colonização, na qual as células começam a se multiplicar e a promover o crescimento da biomassa, sendo que as novas células permanecem aderidas umas às outras, formando o biofilme.

JENKINSON \& LAPPIN-SCOTT (2001) descreveram o desenvolvimento do biofilme como um ciclo de vida, no qual vários fatores ambientais, biológicos e físicos interferem nos estágios de evolução, descritos na FIGURA 3.4. A adesão inicial do biofilme à superfície é um evento aleatório influenciado pela energia livre de superfície e pela proximidade de células microbianas. As células aderidas promovem a divisão celular, colonizam a superfície e, assim, fornecem mais células para adesão e acumulação. Este biofilme é dinâmico: células entram e saem continuamente da comunidade, promovendo diversificação ou dispersão. Forças de cisalhamento, promovidas pelas velocidades aplicadas aos sistemas, interferem na remodelagem da estrutura do biofilme.

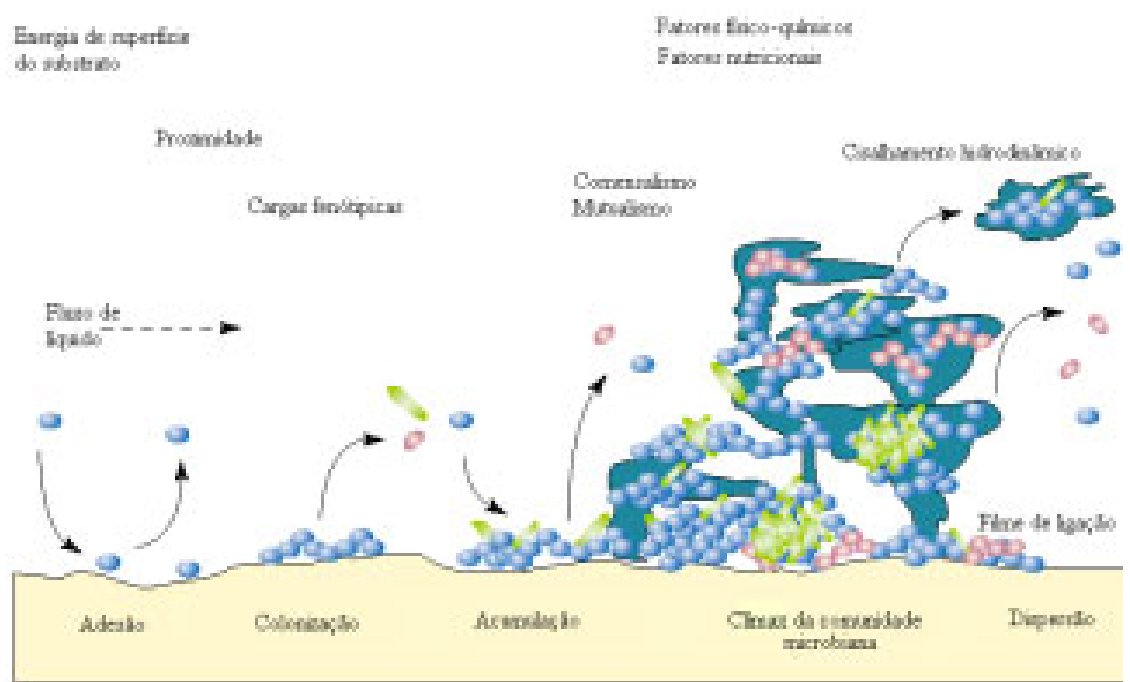

Fonte: Adaptado de JENKINSON \& LAPPIN-SCOTT (2001).

FIGURA 3.4 - Ciclo de desenvolvimento do biofilme. 
VERRIER et al. (1987) consideraram a instalação da primeira camada de bactérias o fenômeno de maior importância para o desenvolvimento futuro do biofilme. De fato, Van LOOSDRECHT et al. (1990) estudaram a influência de interfaces na atividade microbiana e afirmaram que os microrganismos em suspensão se comportam aproximadamente como partículas coloidais. A partir dessa hipótese, a etapa inicial de aderência pode ser descrita pela teoria DLVO, da química dos colóides, que descreve as mudanças na energia livre de Gibbs como função da distância entre dois corpos. A energia livre de Gibbs pode ser obtida pela somatória das interações eletrostáticas e de Van der Waals. As forças de Van der Waals são, geralmente, atrativas. Por sua vez, as forças eletrostáticas são, normalmente, repulsivas, devido ao fato de a natureza de ambas as superfícies, célula e sólido, serem, predominantemente, carregadas negativamente.

ALIBHAI \& FOSTER (1986) estudaram o processo de granulação em reatores UASB e concluíram que os polímeros extracelulares, compostos por polissacarídeos e polipeptídios, são excretados por microrganismos e contribuem para a aderência entre diferentes espécies sintróficas de arqueas metanogênicas e de bactérias acetogênicas presentes nos grânulos provenientes de reatores anaeróbios. Isso causa a estabilidade desses grânulos.

Segundo COSTERTON et al. (1978), o processo de aderência de microrganismos à superfícies inertes e a outros microrganismos pode acontecer por emaranhados de fibras de polissacarídeos ou feixes de moléculas de açúcar. Essas fibras formam o glicocálix, que pode envolver uma célula individual ou uma colônia de células, estendendo-se desde a superfície do microrganismo até a interface do sólido ou de outra célula. O glicocálix é formado a partir da superfície da membrana do microrganismo, composta de camada dupla de moléculas de lipídios, onde são inseridas moléculas de proteínas. A natureza química do glicocálix varia em relação à composição das fibras e de acordo com o estágio de vida em que as células se encontram. 


\subsection{Microbiologia em reatores anaeróbios}

A microestrutura de grânulos de ASBR para tratar substrato sintético foi estudada por BANIK et al. (1997), às temperaturas de 5,15 e $25^{\circ} \mathrm{C}$. As amostras foram analisadas por microscopia eletrônica de varredura. Os autores concluíram que nas diferentes condições de temperatura não houve variação significativa na estrutura microbiana dos grânulos. A 15 e $25^{\circ} \mathrm{C}$, os grânulos exibiram estruturas uniformes, com predominância de microrganismos do gênero Methanothrix, enquanto nos grânulos a $5^{\circ} \mathrm{C}$ observou-se existência de estruturas em camadas, sugerindo que a temperatura também representa papel importante na composição de grânulos. Os autores sugerem que o gênero Methanothrix representa importante função na granulação e retenção de processos anaeróbios de alto desempenho, tais como ASBR. A atividade metanogênica específica em temperatura psicrofílica foi ligeiramente menor que nas mesofílicas.

VERRIER et al. (1988) observaram, em ensaios "in vitro" com culturas puras de arqueas metanogênicas, que superfícies hidrofóbicas como teflon, polipropileno e polietileno favoreceram adesão de microrganismos hidrofóbicos, como as Methanothrix soehnginii, cuja adesão aconteceu mais rapidamente. Segundo os autores, aparentemente, os microrganismos têm a tendência de ficarem aderidos à superfícies semelhantes à sua parede celular (hidrofobicidade); por outro lado, não houve boa adesão de Methanosarcina mazei a esses suportes, que não esteve diretamente envolvida na adesão inicial aos materiais suportes.

Os estudos de Van LOOSDRECHT et al. (1987) confirmaram que as células hidrofóbicas aderem-se muito melhor do que células hidrofílicas. Os autores estudaram a função da hidrofobicidade da parede celular microbiana na adesão e concluíram que a extensão da adesão está correlacionada ao ângulo de contato entre célula e superfície.

MERAZ et al. (1995) observaram a dinâmica de imobilização de microrganismos anaeróbios em material suporte inerte, como partículas finas de polietileno. Os autores concluíram que as atividades acetoclásticas de biopartículas mesofílicas e termofílicas foram 
muito baixas depois do processo de imobilização. No inóculo utilizado foram encontrados microrganismos do gênero Methanothrix nos dois grupos de biopartículas. Baixa atividade e fixação da biomassa sobre o material suporte, provavelmente, foram devidas às forças de cisalhamento, às quais as partículas estiveram sujeitas durante o processo de imobilização.

TOMMASO et al. (2002) estudou a dinâmica do processo de formação do biofilme em espuma de poliuretano no tratamento de esgoto sintético, usando gelatina (fonte de proteína) como base do substrato. As primeiras amostras, correspondentes ao sexto dia de operação, apresentaram cores amareladas ou negras, que dependeram da posição da amostra no reator. Nas amostras amareladas, havia predominância de pequenos bacilos semelhantes a Clostridium sp., bactérias essas responsáveis pelo metabolismo de múltiplos aminoácidos na fase fermentativa. Também foram encontrados bacilos curvos semelhantes a Dessulfovibrio sp. e microrganismos com morfologias semelhantes a cocos, provavelmente Staphylococcus sp. e Streptococcus sp. Bacilos e cocos predominaram nas amostras de coloração negra, provavelmente devido às arqueas metanogênicas Methanobacterium, Methanobrevibacter e Methanococus, que são hidrogenotróficas.

RIBEIRO (2001) avaliou a influência do tipo de substrato na dinâmica de formação do biofilme em matrizes de espuma de poliuretano. Utilizou diferentes substratos na alimentação de reatores diferenciais, como extrato de carne, glicose, amido, lipídeos e esgoto sanitário sintético. Concluiu que todos os ciclos estudados apresentaram grande variabilidade morfológica em relação ao substrato utilizado. Foi verificada ocorrência persistente e mais intensa de organismos semelhantes a Methanosaeta sp. em relação aos semelhantes a Methanosarcina sp. Porém, foi observada maior diversidade morfológica no ensaio com esgoto sanitário sintético, fato vinculado, provavelmente, à maior complexidade do substrato.

As morfologias encontradas por VERONEZ et al. (2002), na operação de ASBR em batelada e batelada alimentada, foram predominantemente bacilos, com grande presença de 
cocos, de células semelhantes a Methanosaeta sp. e Methanosarcina sp., bacilos e cocos fluorescentes, filamentos e víbrios.

ANGENENT et al. (2002b) estudaram a dinâmica da população metanogênica durante a partida de ASBR tratando resíduos de suinocultura. Concluíram que, provavelmente, durante a operação com altos níveis de amônia, a principal rota de produção de metano ocorresse através da relação sintrófica entre bactérias oxidantes de acetato e metanogênicas utilizadoras de hidrogênio.

\subsection{Considerações finais}

A partir da revisão da literatura, foi obtido melhor entendimento de várias questões relacionadas ao tratamento de efluente anaeróbio. As informações obtidas permitiram a ampliação dos conhecimentos referentes ao reator anaeróbio em batelada seqüencial (ASBR), concebido a partir de observações em estudos de lodos ativados anaeróbios que têm sido estudados ao longo da última década.

Através de informações obtidas nas diversas pesquisas com ASBR foi possível observar que houve progresso na concepção desse tipo de reator. A introdução de materiais inertes para imobilização da biomassa, permitiu que se mantivesse elevado o tempo de retenção celular, sem necessidade do tempo de sedimentação para clarificação do efluente. Introduziu-se, também, a agitação mecânica para favorecer a transferência de massa e promover melhor homogeneização do reator. Porém, por se tratar de tecnologia recente, devem ser aprimorados estudos dos fundamentos desse processo.

A imobilização da biomassa pode ser realizada com usos de ampla gama de materiais. A literatura reporta diversas pesquisas que enfocam a utilização de suportes inertes no tratamento anaeróbio de águas residuárias. $\mathrm{Na}$ busca de entendimento do processo de aderência dos microrganismos, é necessário o conhecimento de alguns fundamentos de 
microbiologia, de formação de biofilmes, das interações físico-químicas e das características dos materiais utilizados.

De posse dos dados experimentais, é possível a determinação dos parâmetros cinéticos que, na maioria das vezes, são específicos para as condições experimentais empregadas. Entretanto, tais parâmetros são fundamentais para o conhecimento das velocidades de consumo de substratos, formação de produtos, morte celular, constante de afinidade, etc.

Através da revisão da literatura, com o objetivo de avaliar o desempenho do ASBR, de leito fixo de pedra pome sintética, no tratamento de esgoto sanitário, obteve-se melhor compreensão dos diversos assuntos relacionados a esta pesquisa de mestrado, auxiliando nas discussões dos resultados obtidos neste trabalho. 


\section{MATERIAL E MÉtodoS}

Neste capítulo, descreve-se a instalação experimental utilizada para realização da pesquisa, bem como detalhes do reator, equipamentos e materiais utilizados e procedimentos experimentais adotados. Apresentam-se, também, os métodos adotados para análise das amostras, para caracterização do material suporte e microbiologia do biofilme anaeróbio (FIGURA 4.1).

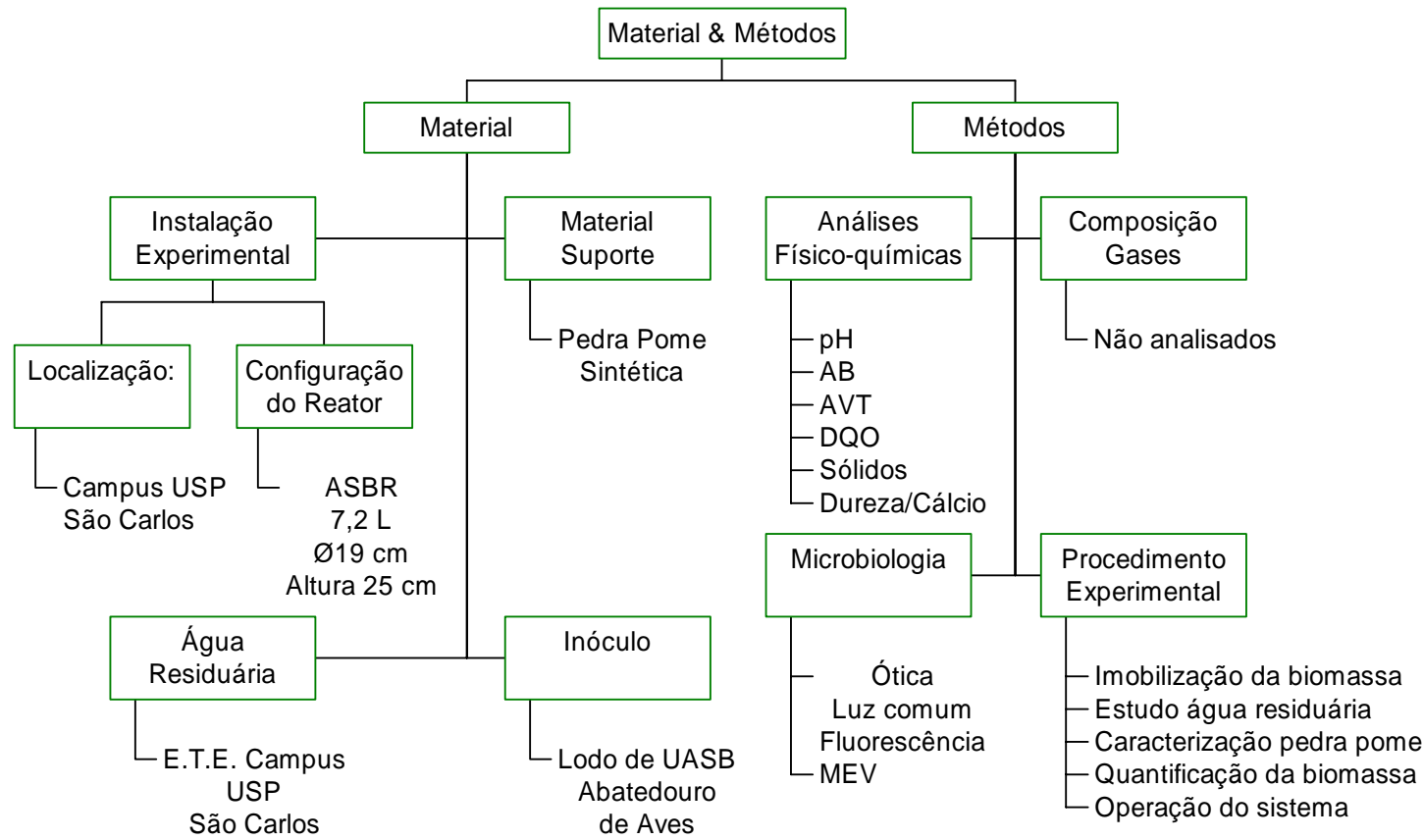

FIGURA 4.1 - Organograma do projeto de pesquisa 


\subsection{Material}

\subsubsection{Descrição da instalação experimental}

\subsubsection{Local de instalação e operação do sistema}

A instalação e operação do sistema, foram levadas a efeito na cidade de São Carlos, no Campus da Universidade de São Paulo. Sua localização dentro do Campus pode ser visualizada no mapa esquemático apresentado na FIGURA 4.2.

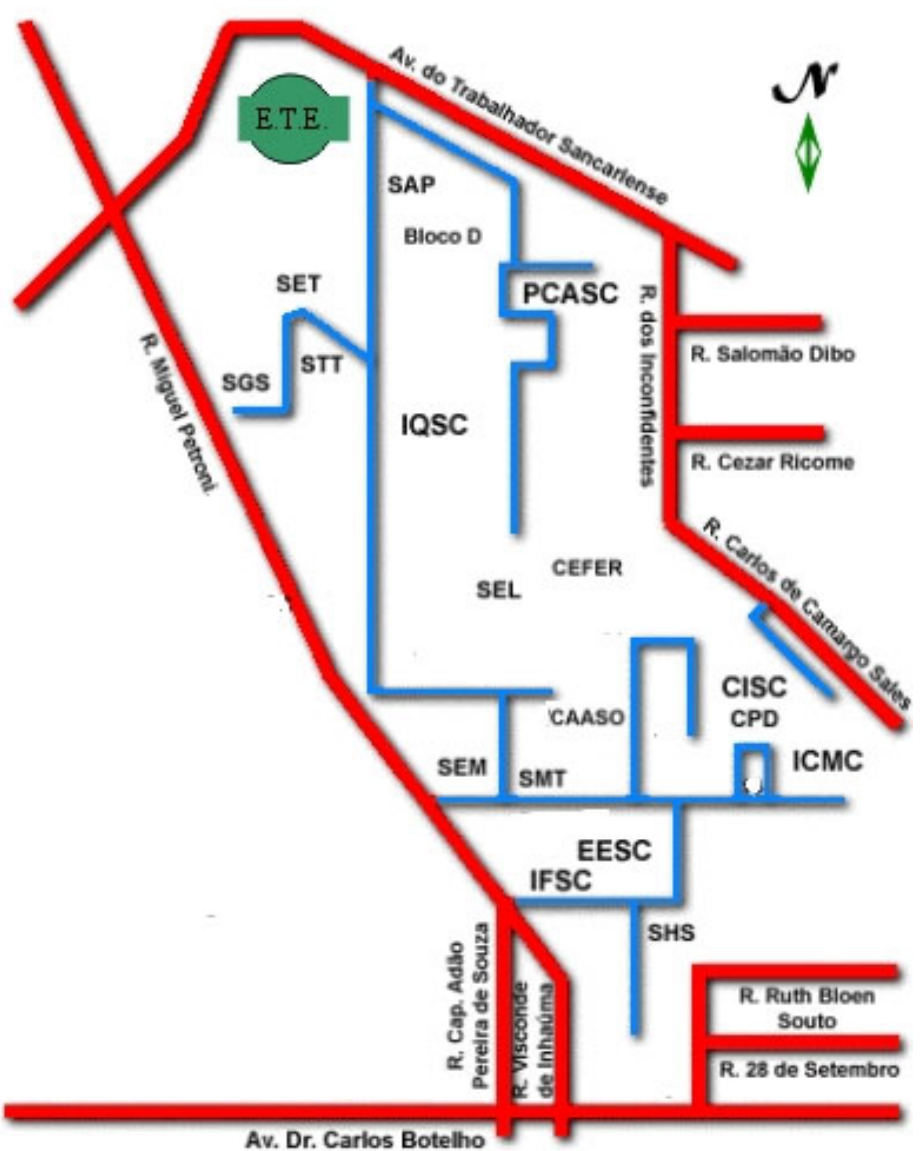

FIGURA 4.2 - Mapa do Campus da Universidade de São Paulo - São Carlos - SP. Detalhe da localização da instalação experimental, demarcada como E.T.E. (em verde). 


\subsubsection{Configuração do reator anaeróbio em batelada seqüencial}

O sistema em escala de bancada foi composto por: reator anaeróbio em batelada seqüencial, agitador mecânico, banho ultratermostatizado, três bombas tipo diafragma e três timers.

O reator anaeróbio em batelada seqüencial, constituído por dois tubos concêntricos de acrílico, com diâmetros internos iguais a $19 \mathrm{~cm}$ e $22 \mathrm{~cm}$, apresentava altura de $25 \mathrm{~cm}$ e volume total de 7,2 L. Foi previsto fundo cônico para facilitar a limpeza do reator.

A função do tubo externo foi permitir a circulação de água aquecida a $30 \pm 1^{\circ} \mathrm{C}$, em banho ultratermostatizado Marconi, modelo BTC-9090. A alimentação e a descarga foram realizadas por meio de bombas tipo diafragma, marca Prominente, modelo Concept. A terceira bomba, de mesma marca e modelo, foi utilizada para coleta de amostras e limpeza da tubulação de esgoto sanitário que alimentava o reator.

O material suporte foi confinado em um cesto (FIGURA 4.3), de tela de aço inox 316, com malha de $0,5 \mathrm{~cm}$ e arestas feitas com anéis de acrílico, para dar sustentação, com dimensões de 17,5 cm externo e $7 \mathrm{~cm}$ interno, altura de $18 \mathrm{~cm}$, correspondentes ao volume de 3,64 L. O esquema da montagem do sistema pode ser visto na FIGURA 4.3.

A agitação foi suprida por meio de agitador mecânico, marca Marconi, modelo MA 259, com 2 impelidores tipo turbina, lâmina plana (FIGURA 4.3), posicionados na haste de agitação a $1 / 3$ e a $2 / 3$ do fundo do cesto de inox. 


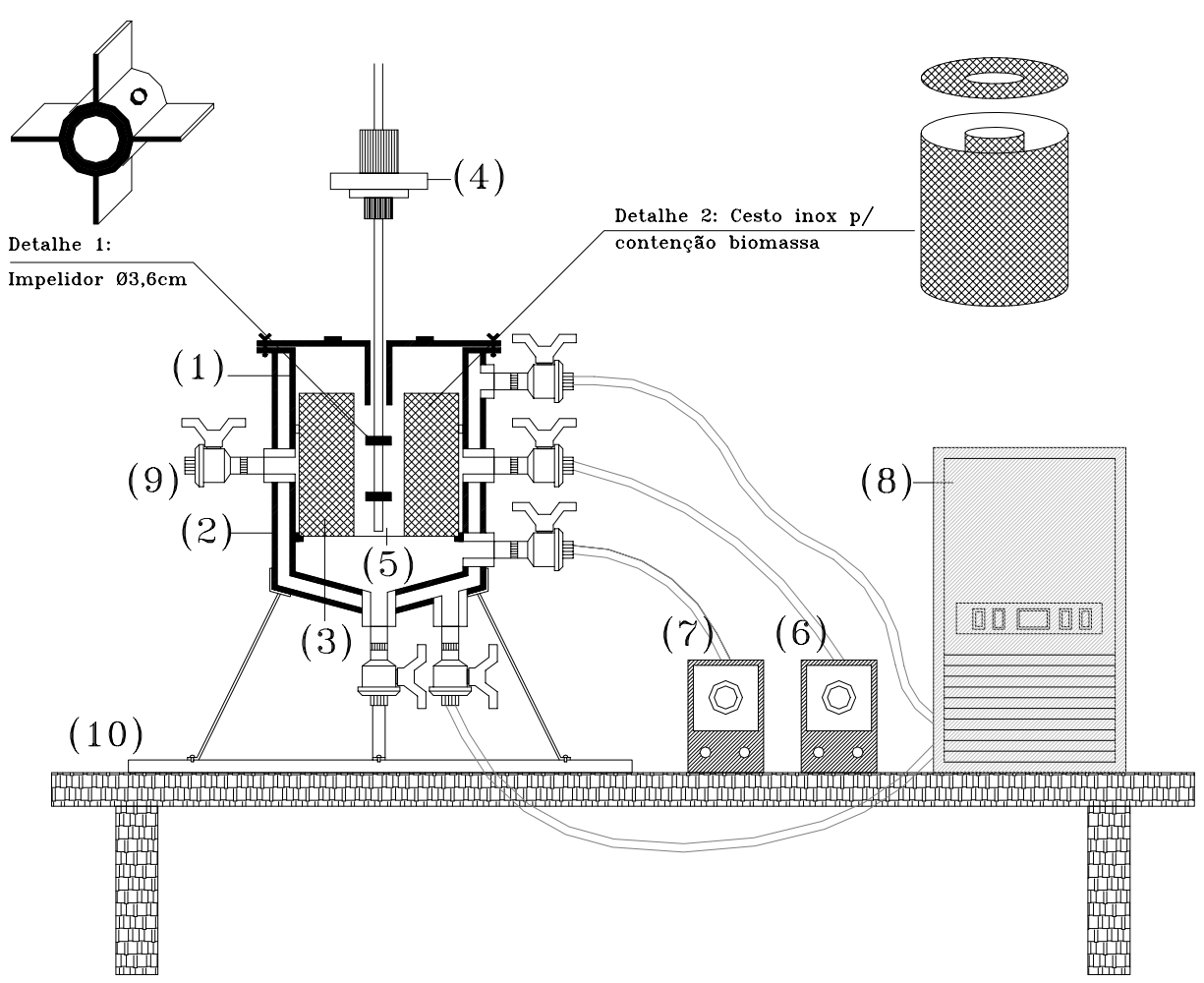

FIGURA 4.3 - Esquema do aparato experimental, sendo (1) reator anaeróbio em batelada seqüencial, (2) camisa de aquecimento, (3) cesto inox, (4) agitador mecânico, (5) impelidor, (6) bomba de diafragma alimentação, (7) bomba de diafragma - descarga, (8) banho ultratermostatizado, (9) amostrador e (10) bancada.

\subsubsection{Material suporte para imobilização da biomassa - pedra pome}

Como material suporte para imobilização da biomassa foram utilizadas matrizes de pedra pome sintética, na forma de cubos, com arestas de $1 \mathrm{~cm}$ de lado (FIGURA 4.4b). Essas matrizes foram cortadas e fornecidas pela empresa Fernando Teixeira Dosualdo - ME, São José do Rio Preto - SP. A fabricação da pedra pome sintética no Brasil é realizada pela empresa Sical Industrial Ltda, Belo Horizonte-MG.

O cesto de inox (FIGURA 4.4a) foi preenchido com 2.000 cubos de pedra pome, o que corresponde ao volume de $2 \mathrm{~L}$. A massa de pedra pome foi de, aproximadamente, $765 \mathrm{~g}$ e ocuparam, cerca de, $28 \%$ do volume reacional. 


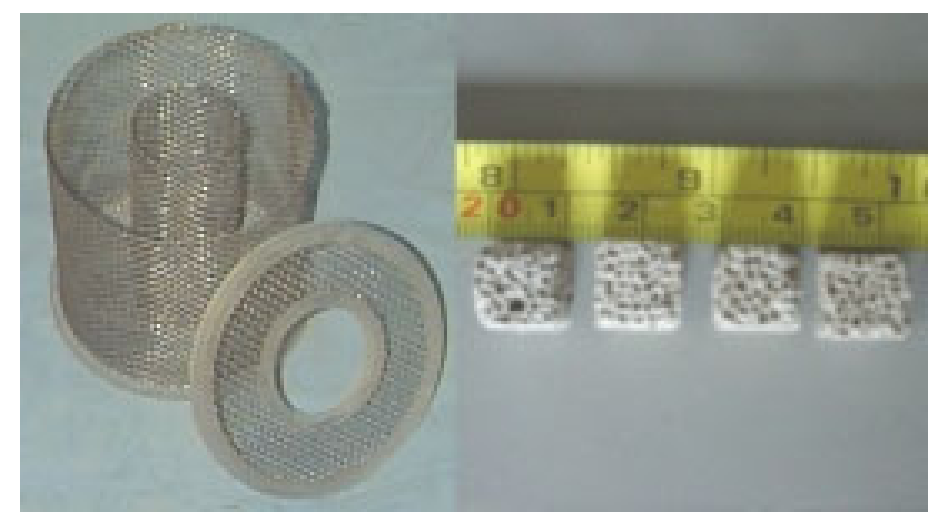

(a)

(b)

FIGURA 4.4 - (a) Cesto de tela de inox vazio e (b) pedra pome sintética, antes da inoculação.

\subsection{3. Água residuária}

Foi utilizado esgoto proveniente da rede coletora (FIGURA 4.5a) que passa pelo Campus da USP em São Carlos. Essa rede atende, além da USP, dois bairros da cidade: Vila São José e Vila Pureza.

A água residuária era recalcada durante as 24 horas do dia, com bomba diafragma Ecosan BDN2 (FIGURA 4.5b) e armazenada em reservatório de 750 L (FIGURA 4.5c). No interior do reservatório, foram instaladas duas telas com malha de $2 \mathrm{~mm}$, para retirada da fração de sólidos em suspensão, com dimensões inconvenientes para o tamanho das unidades experimentais. Esse reservatório funcionou como tanque de equalização do esgoto afluente ao sistema. 


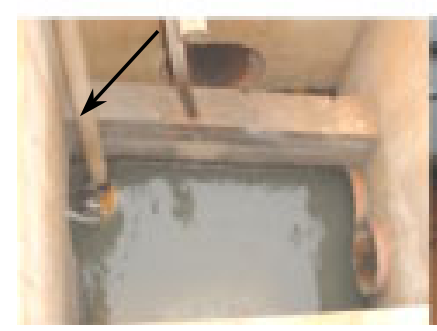

(a)

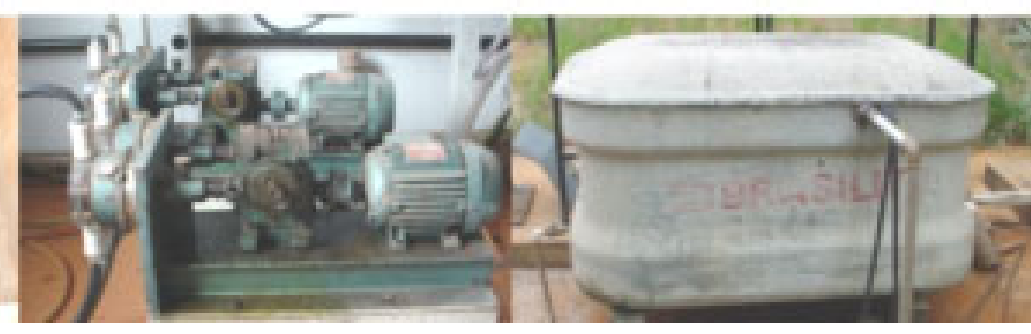

(b) (c)

FIGURA 4.5 - Sistema de coleta e armazenamento do esgoto sanitário afluente: (a) rede de esgoto sanitário, ponto de captação, (b) bomba de recalque e (c) caixa de armazenamento.

\subsubsection{Inóculo}

O reator foi inoculado com lodo proveniente de reator UASB, da Estação de Tratamento de Águas Residuárias de Abatedouro de Aves, empresa Avícola Dacar S.A., sediada em Tietê - SP. A escolha desse inóculo deveu-se, principalmente, às características e por ser proveniente de um reator UASB que está em operação há muito tempo, apresentando alta eficiência e estabilidade de operação, no tratamento das águas residuárias do abatedouro de aves.

\subsection{Métodos}

\subsubsection{Análises físico-químicas}

O monitoramento do reator foi realizado através de análises de amostras coletadas no afluente e no efluente da primeira batelada diária. Foram determinados os seguintes parâmetros: demanda química de oxigênio (DQO), pH, sólidos totais ( $\mathrm{ST}$ ) e sólidos suspensos (SS), de acordo com os respectivos métodos descritos pelo STANDARD METHODS FOR EXAMINATION OF WATER AND WASTEWATER (1998). A concentração de ácidos voláteis totais (AVT) - como ácido acético - foi determinada de acordo com método descrito por DILALLO \& ALBERTSON (1961) e a alcalinidade a 
bicarbonato $(\mathrm{AB})$ - como $\mathrm{CaCO}_{3}$ - foi analisada de acordo com método descrito por DILALLO \& ALBERTSON (1961), modificado por RIPLEY et al. (1986).

A frequiência das análises foi de três vezes por semana. Após atingida a estabilidade operacional do sistema, ou seja, quando as características analisadas não variaram significativamente entre duas bateladas, foram realizados perfis temporais de DQO, AVT, $\mathrm{AB}, \mathrm{pH}$ e potencial de oxi-redução ( $\mathrm{POR}$ ), para avaliação do comportamento do reator frente aos parâmetros de monitoramento adotados.

Eventualmente, devido aos resultados obtidos de sólidos totais no efluente, foram quantificadas a dureza e a concentração de cálcio de amostras do afluente e efluente, de acordo com metodologias propostas pelo STANDARD METHODS FOR EXAMINATION OF WATER AND WASTEWATER (1998).

\subsubsection{Quantificação e composição dos gases}

A composição dos gases não foi monitorada devido à baixa produção nesse reator de bancada, para tratamento de esgoto sanitário. Além disso, essa análise poderia sofrer interferência devido à distância entre a instalação experimental e o Laboratório de Processos Biológicos, onde está instalado o cromatógrafo a gás.

\subsubsection{Exames microbiológicos}

Foram realizadas observações ao microscópio da biomassa presente no lodo de inóculo no início da operação e nas pedras pomes no meio e no final da operação. As amostras foram examinadas por microscopia ótica de luz comum e de fluorescência utilizando-se microscópio Leica DM LB, com software de análise de imagens, Image Pro Plus 4.5 - e através de microscopia eletrônica de varredura (MEV) - utilizando-se microscópio de varredura digital LEO-440. 
Para a MEV, as amostras foram preparadas de acordo com protocolo estabelecido por NATION (1983) e adaptado para biofilmes microbianos por ARAÚJO (1995). Primeiramente, foi realizada a fixação das amostras com glutaraldeído (GTA) 2,5\% em tampão fosfato $0,1 \mathrm{M}, \mathrm{pH} 7,3$, gelado. As amostras foram deixadas na geladeira por 12 horas à temperatura de $4^{\circ} \mathrm{C}$. Decorrido esse período, procedeu-se à lavagem das amostras por 3 vezes, com tampão fosfato $0,1 \mathrm{M}, \mathrm{pH} 7,3$, gelado, sendo de 10 minutos a duração de cada lavagem. Em seguida, foi realizada a desidratação em álcool etílico nas concentrações de 50, 70, 80, 90, 95 e 100\%. Cada operação de desidratação teve a duração de 10 minutos. Por fim, as amostras foram aderidas aos suportes de MEV e transferidas para estufa, com temperatura inferior a $40^{\circ} \mathrm{C}$, por 2 horas para, posteriormente, serem submetidas ao recobrimento com ouro. Após esse último procedimento, foram levadas ao MEV.

\subsubsection{Procedimento experimental}

\subsubsection{Imobilização da biomassa anaeróbia}

O lodo anaeróbio utilizado como inóculo foi coletado em julho de 2002 e mantido em geladeira até a operação de inoculação. A imobilização foi realizada em partículas cúbicas de pedra pome aos 24 de setembro de 2002. As partículas de pedra pome foram colocadas em recipiente, ao qual foi adicionado lodo granular - anteriormente triturado em liquidificador - até que toda a pedra pome estivesse em contato com a suspensão. $O$ recipiente foi vedado com filme de PVC e permaneceu sob temperatura controlada de $30 \pm$ $1^{\circ} \mathrm{C}$ por 24 horas. Decorrido esse período, as matrizes com as células aderidas foram submetidas à peneiramento, para eliminação do lodo não aderido ao meio suporte. A seguir, as matrizes de pedra pome foram colocadas dentro do cesto, de forma uniforme, sem pressionamento, para evitar possíveis entupimentos ou adensamento excessivo do leito. 


\subsubsection{Estudo da água residuária}

Foram realizados dois perfis de 24 horas no esgoto sanitário, com coleta de amostras a cada 2 horas, armazenado no reservatório de 750 L; em julho e em outubro de 2002 . O objetivo principal desse estudo foi avaliar se era ou não significativa a variação da concentração de esgoto sanitário, expressa como DQO, no decorrer do período de $24 \mathrm{~h}$. Essa informação foi importante para a escolha da batelada do dia a ser monitorada através das análises físico-químicas de amostras coletadas do reator.

\subsubsection{Caracterização do material suporte - pedra pome sintética}

O material suporte foi caracterizado física e quimicamente por meio de análises de área superficial, tamanho de poros e porosidade, distribuição dos tamanhos de partículas, determinação da densidade real, composição mineral através de difração de raios $\mathrm{X}$ e caracterização do material por microscópio eletrônico de varredura (MEV).

Para obtenção da densidade real foi utilizado o princípio de Arquimedes de deslocamento de fluídos (gás hélio), com uso do equipamento Ultrapycnometer 1000 da Quantachrome. A determinação da porosidade e do tamanho de poros foram realizadas por intrusão de mercúrio, através da aplicação de pressão, para faixa de tamanho de poros de 0,006 a 360 mícrons, com pressão máxima de 30.000 psi. Foi utilizado o equipamento Porosizer 9.320, da Micromeritics. A determinação da área superficial foi realizada a partir da adsorção física de gás inerte (nitrogênio). O tamanho de poros à pressão atmosférica também foi determinado por intrusão de mercúrio, à pressão de 12,8 psi.

A análise morfológica foi realizada em microscópio eletrônico de varredura (MEV Stereoscan 440 - LEO), acoplado ao equipamento EDS (Energy Dispersion Spectroscopy Espectroscopia por Energia Dispersiva - eXL - Oxford). Os elementos químicos da amostra foram identificados e quantificados de acordo com um método que fornece valores aproximados -elementos com peso atômico entre o carbono e o urânio. 
A caracterização estrutural foi feita via difração de raios-X (D5000 Kristalloflex Siemens). Devido às limitações do equipamento não foram detectadas fases não cristalinas, ou com concentração abaixo de $5 \%$.

\subsubsection{Quantificação da biomassa aderida}

A biomassa aderida à pedra pome foi quantificada de modo a obter-se massa de biomassa por partícula de pedra pome. Para isso, amostras do suporte passaram por idênticos processos, antes e após a operação do reator. Inicialmente, amostras lavadas e secas em estufa foram pesadas e posteriormente calcinadas e pesadas novamente. Após a operação, amostras do suporte, imobilizado pela biomassa, também foram secos em estuda, pesados, calcinados e pesados novamente. A metodologia seguida foi a mesma para a análise de sólidos totais prescrita no STANDARD METHODS FOR EXAMINATION OF WATER AND WASTEWATER (1998). A massa da pedra pome sem biomassa, secada na estufa $\left(100^{\circ} \mathrm{C}\right)$ foi utilizada no cálculo da densidade aparente, ou seja, a massa de pedra pome contida em uma unidade de aproximadamente $1 \mathrm{~cm}^{3}$.

\subsubsection{Operação do sistema}

Os sistema foi montado em escala de bancada, conforme projetado e descrito no item 4.1.1.2. Na FIGURA 4.6 pode-se visualizar o aparato experimental após sua instalação.

A operação do sistema foi iniciada aos 24 de setembro de 2002 e finalizada aos 17 de dezembro de 2002, em um total de 86 dias. Antes de iniciar a operação do reator, foi realizada uma bateria de testes utilizando-se água, a fim de previnir-se possíveis problemas de vazamento de esgoto sanitário. Também foram reguladas as vazões das bombas para que tanto a etapa de enchimento, como a de descarga ocorressem em 10 minutos. O tempo de ciclo total adotado foi de 8 horas, que compreende 10 minutos de enchimento, 460 minutos (7h40min) de reação e 10 minutos de descarga. A agitação mecânica adotada de projeto foi 300 rpm, com uso de 2 impelidores tipo turbina, de lâminas planas verticais. Esses 
parâmetros foram adotados a fim de promover melhor contato do substrato com os microrganismos e facilitar a transferência de massa. $\mathrm{O}$ reator foi mantido à temperatura de $30 \pm 1^{\circ} \mathrm{C}$, com uso de banho ultratermostático.

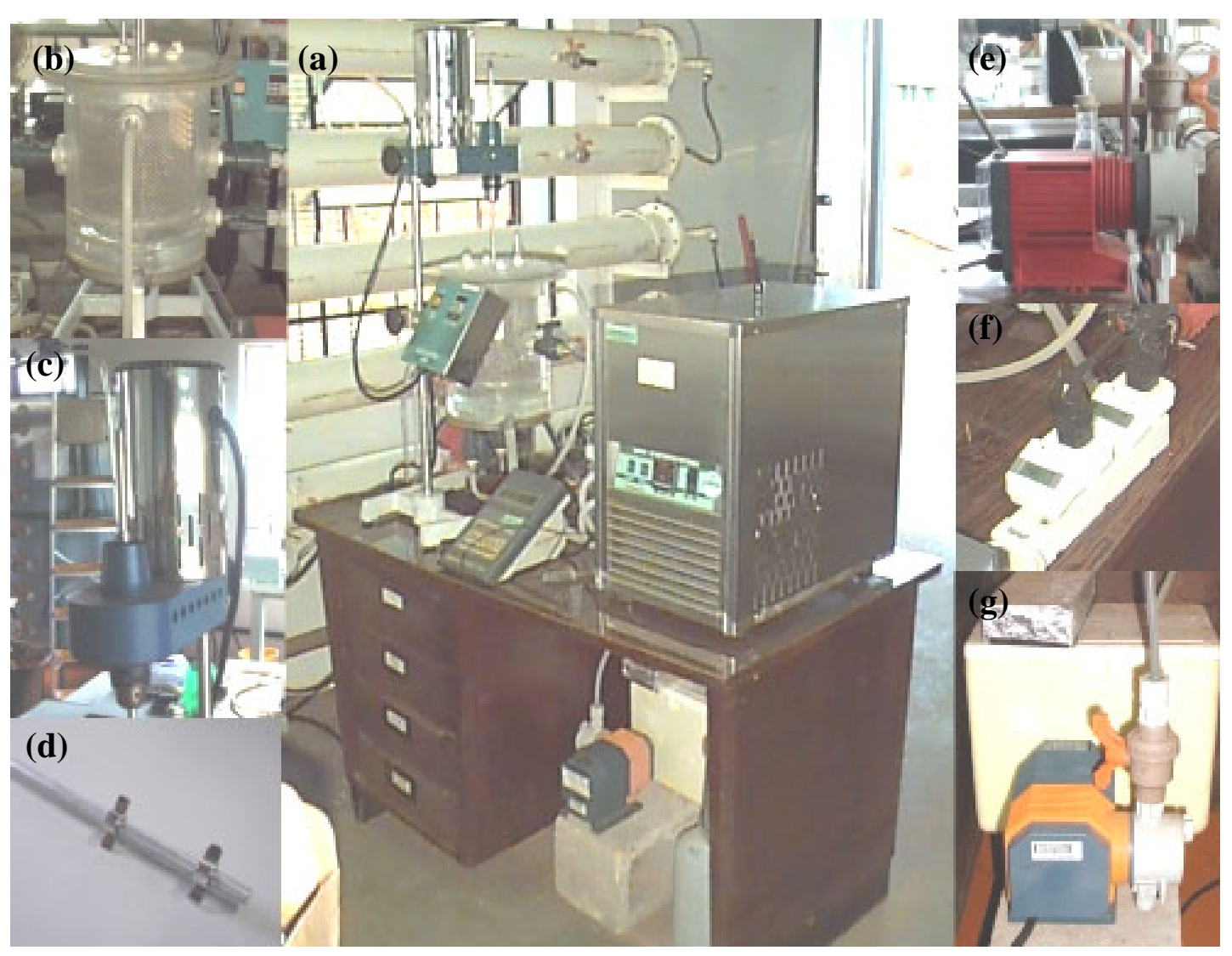

FIGURA 4.6 - (a) Instalação experimental, (b) reator anaeróbio em batelada seqüencial, (c) agitador mecânico, (d) haste com impelidores, (e) bomba de carga e descarga, (f) timers e (g) caixa de amostragem e bomba amostradora.

Após a inoculação, teve início o primeiro ciclo de operação, com duração total de 24 horas. Foram adotados 12 ciclos de 24 horas e 14 ciclos $\left(13^{\circ}\right.$ ao $26^{\circ}$ ciclo) de 12 horas, sem agitação. Essa fase do trabalho, com tempos de ciclo maiores, sem agitação, foi escolhida com o objetivo de minimizar a perda de sólidos e, conseqüentemente, de biomassa, comuns durante o período de partida de reatores biológicos. Após esse período, no $27^{\circ}$ ciclo, o tempo de cada batelada passou para 8 horas, com agitação mecânica de 100 rpm, por três ciclos consecutivos. A partir do $28^{\circ}$ ciclo, as condições de projeto foram estabelecidas, com 
bateladas de 8 horas, agitação mecânica de $300 \mathrm{rpm}$ e temperatura controlada em $30 \pm 1^{\circ} \mathrm{C}$. Essas condições operacionais foram mantidas até o final da fase experimental.

Do volume total do reator $(7,2 \mathrm{~L}), 0,2 \mathrm{~L}$ foram destinados ao headspace e $0,8 \mathrm{~L}$ de esgoto foram mantidos no reator, devido ao volume retido no fundo cônico. Portanto, como a pedra pome ocupou volume de 2,0 L, o volume reacional foi de 5,0 L e o volume tratado, em cada batelada foi, de 4,2 L. Isso corresponde a 12,6 L de esgoto sanitário tratado por dia. Como o reator possuía volume total de 7,2 L, a carga hidráulica tratada foi de 1,75 L/L.dia. 


\section{ReSultados E Discussões}

\subsection{Perfis temporais da água residuária afluente}

Foram realizados dois perfis de 24 horas do esgoto sanitário armazenado no reservatório de $750 \mathrm{~L}$, nos meses de julho e outubro de 2002. O objetivo principal desse estudo foi avaliar se era ou não significativa a variação horária da concentração de matéria orgânica no esgoto sanitário, expresso como DQO, para escolha da batelada do dia a ser analisada.

Os resultados apresentados na FIGURA 5.1 demonstram que não foi significativa a variação da concentração de matéria orgânica do esgoto sanitário armazenado, no período de 24 horas. Em julho de 2002, o esgoto sanitário apresentou valor médio de DQO de $307 \pm 10$ mg/L e de DQO filtrada de $201 \pm 27 \mathrm{mg} / \mathrm{L}$. Em outubro de 2002 o valor médio de DQO foi de $418 \pm 41 \mathrm{mg} / \mathrm{L}$ e de DQO filtrada foi de $275 \pm 26 \mathrm{mg} / \mathrm{L}$.

O perfil realizado no mês de julho apresentou diferença negativa de, aproximadamente, $100 \mathrm{mg} / \mathrm{L}$ nos valores de DQO, em relação ao de outubro. Provavelmente decorrente do período de férias escolares e do não funcionamento do restaurante universitário da USP.

Assim, poderia ser escolhido qualquer horário para a realização das análises, pois a concentração de matéria orgânica no esgoto sanitário não apresentou variação significativa, durante as 24 horas do dia. Portanto, foi escolhido o período de 8 às 16 horas para monitoramento do sistema, que enquadrou-se dentro do horário comercial de trabalho e funcionamento do laboratório. 


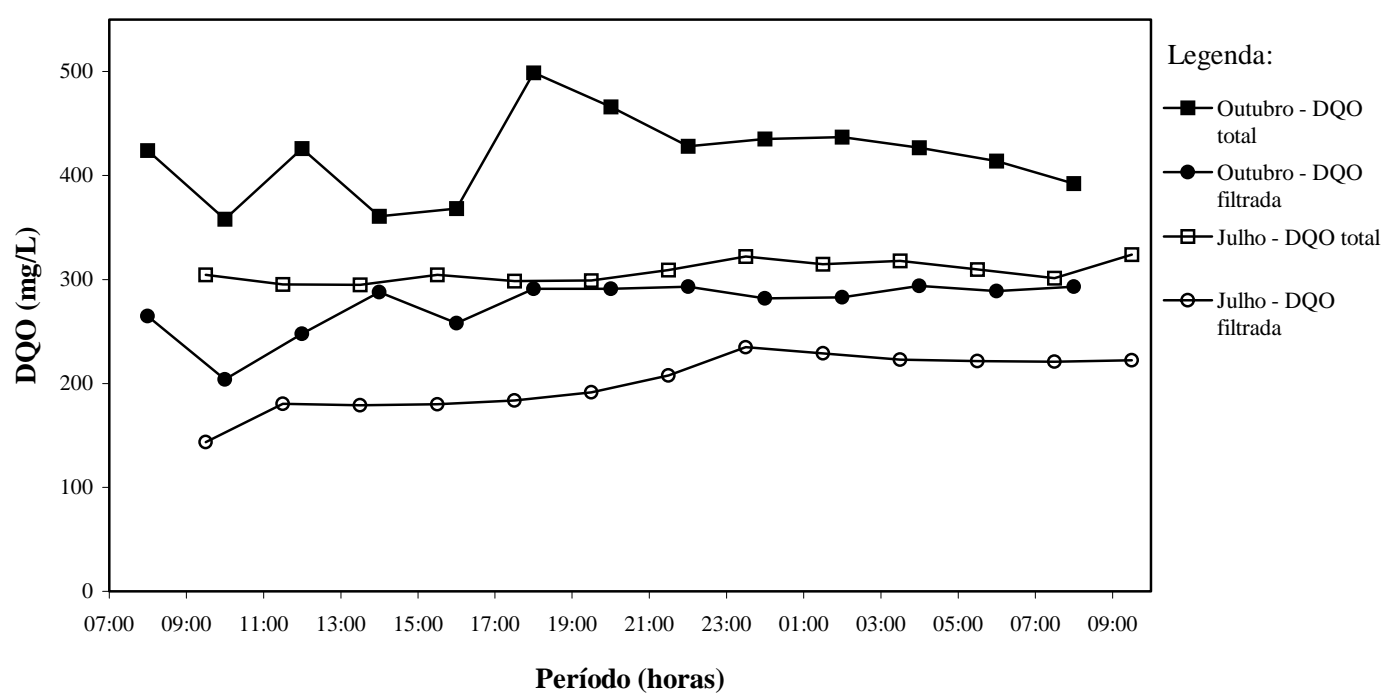

FIGURA 5.1 - Perfis temporais da concentração de esgoto sanitário no reservatório de 750 L.

\subsection{Caracterização do material suporte - pedra pome sintética}

A idéia inicial de utilizar a pedra pome sintética como material suporte deveu-se ao fato de ser um material barato, de fácil aquisição e que, a princípio, apresentava características propícias à aderência de microrganismos. No decorrer dos estudos, descobriuse que a pedra pome sintética possui exatamente o mesmo sistema de produção que o concreto celular autoclavado.

Foi realizado o estudo de caracterização do material suporte - pedra pome sintética por meio de diversas análises, realizadas no Centro de Caracterização e Desenvolvimento de Materiais (CCDM), da Universidade Federal de São Carlos (UFScar). Os resultados estão apresentados na TABELA 5.1. 
TABELA 5.1 - Dados obtidos das análises de caracterização da pedra pome.

\begin{tabular}{lcc}
\hline \multicolumn{1}{c}{ Característica } & Unidade & Valor \\
\hline Densidade real & $\mathrm{g} / \mathrm{cm}^{3}$ & $2,64+0,02$ \\
Área superficial & $\mathrm{m}^{2} / \mathrm{g}$ & 21,337 \\
Área total de poros & $\mathrm{m}^{2} / \mathrm{g}$ & 56,428 \\
$\begin{array}{l}\text { Diâmetro médio (volume), a } \\
\text { pressao atmosférica }\end{array}$ & $\mathrm{mm}$ & 57,34 \\
Diâmetro médio (volume) & $\mathrm{mm}$ & 1,136 \\
Média do diâmetro (4V/A) & $\mathrm{mm}$ & 0,078 \\
Densidade volumétrica & $\mathrm{g} / \mathrm{mL}$ & 2,463 \\
Porosidade & $\%$ & 73 \\
& & \\
\hline
\end{tabular}

Segundo o CCDM, a área total de poros é a soma de todos os valores de áreas de poro, diâmetro médio (volume) corresponde a $50 \%$ do volume total de intrusão no gráfico cumulative intrusion volume versus diâmetro e média do diâmetro (4V/A) é obtido da relação área/poro de um poro cilíndrico dado por 4Vtotal/Atotal.

Pode-se observar, nos resultados obtidos, que a pedra pome sintética possui alta porosidade, aproximadamente $73 \%$, assim como alta área total de poros, aproximadamente, $56 \mathrm{~m}^{2} / \mathrm{g}$. A densidade real encontrada desse material foi, aproximadamente, $2,64 \mathrm{~g} / \mathrm{cm}^{3}$ ou $2.640 \mathrm{~kg} / \mathrm{m}^{3}$.

Características como porosidade e área total de poros são bons indicativos para a escolha de materiais suportes (HARENDRANATH et al., 1996). Os resultados apresentados na literatura também atribuem, a essas características, a boa formação de biofilme, pois, quanto maior a área disponível para a colonização microbiana, maior a capacidade de retenção da biomassa e, conseqüentemente, pode-se esperar que o desempenho do reator seja melhor.

Os dados obtidos podem ser comparados aos de outros materiais suportes, analisados também pelo CCDM, e que têm sido utilizados pela equipe de trabalho do Laboratório de Processos Biológicos. Por exemplo, o carvão vegetal apresentou porosidade de, aproximadamente, $43 \%$ e área total de poros de $8 \mathrm{~m}^{2} / \mathrm{g}$. Esses valores são inferiores aos obtidos para a pedra pome, o que pode indicar que ela apresenta potencial para ser bom 
material suporte. A porosidade da espuma de poliuretano é igual a $95 \%$, porém sua densidade real é baixa $\left(20 \mathrm{~kg} / \mathrm{m}^{3}\right)$, podendo causar colmatações do leito do reator. Todavia, a espuma de poliuretano tem apresentado resultados excelentes como material suporte para formação de biofilme, nas investigações realizadas no Laboratório de Processos Biológicos, da EESC-USP.

A densidade aparente da pedra pome foi determinada com a mesma metodologia aplicada para a análise de sólidos, descrita no item 4.2.4.4. O resultado obtido foi de 382 $\mathrm{mg} / \mathrm{cm}^{3}$. A grande diferença entre a densidade real e a aparente, reside no fato de a densidade aparente levar em consideração a porosidade do material, o que o torna bem mais leve.

Os resultados da análise de elementos químicos da pedra pome mostraram que a amostra continha 49,77\% de cálcio, 43,07\% de silício, 3,11\% de ferro, 2,20 \% de alumínio, $1,57 \%$ de oxigênio e $0,32 \%$ de carbono. Assim, a maior parte da pedra pome é composta de cálcio e silício, elementos químicos que, estão presentes em grandes quantidades na areia, cal e cimento.

As imagens da pedra pome podem ser observadas na FIGURA 5.2. Sua superfície é muito porosa e irregular. Os poros têm diversos tamanhos, formas e profundidades. Em alguns pontos, é possível identificar-se cristais de cimento.

As fases cristalinas do material suporte, identificáveis via difração de raios-X, estão apresentadas na FIGURA 5.3. São elas: quartzo $\left(\mathrm{SiO}_{2}\right)$, tobermorita $\left[\mathrm{Ca}_{5} \mathrm{Si}_{6}(\mathrm{O}, \mathrm{OH}, \mathrm{F})_{18^{-}}\right.$ $\left.5 \mathrm{H}_{2} \mathrm{O}\right]$ e calcita $\left(\mathrm{CaCO}_{3}\right)$. 


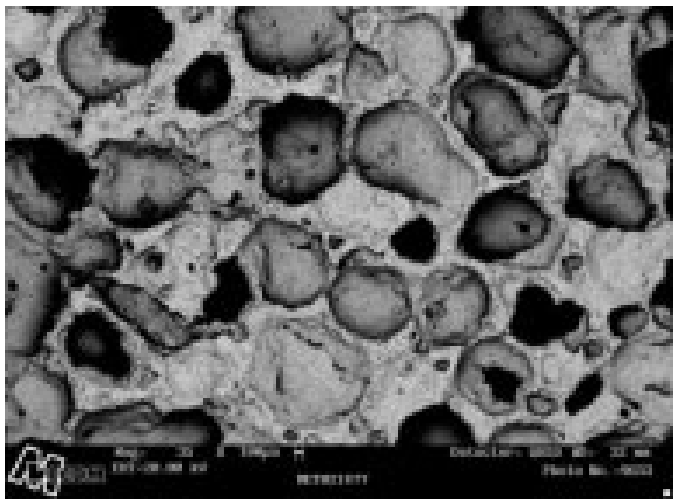

(a)

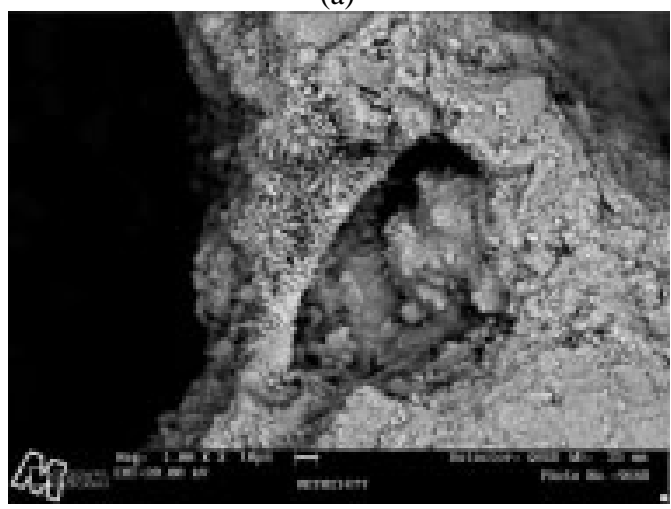

(c)

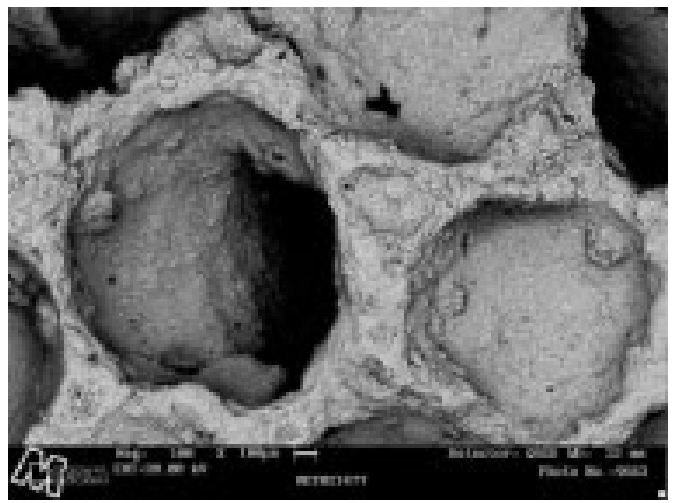

(b)

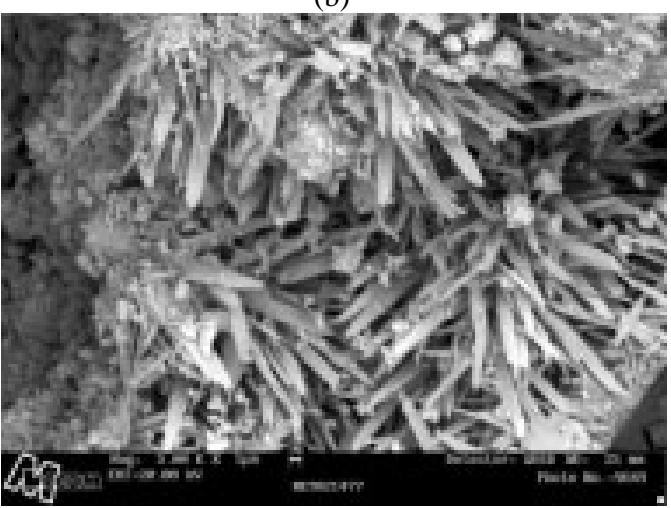

(d)

FIGURA 5.2 - Microscopia eletrônica de varredura de amostras da pedra pome. (a) Superfície porosa com aumento de 35X; (b) ampliação da superfície para 100X, que evidencia a forma e profundidade dos poros; (c) poros de constituição rugosa e irregular, como diversas irregularidades, aumento de 1000X; e (d) ampliação da foto (c) evidenciando estrutura cristalina característica de cristais de cimento.

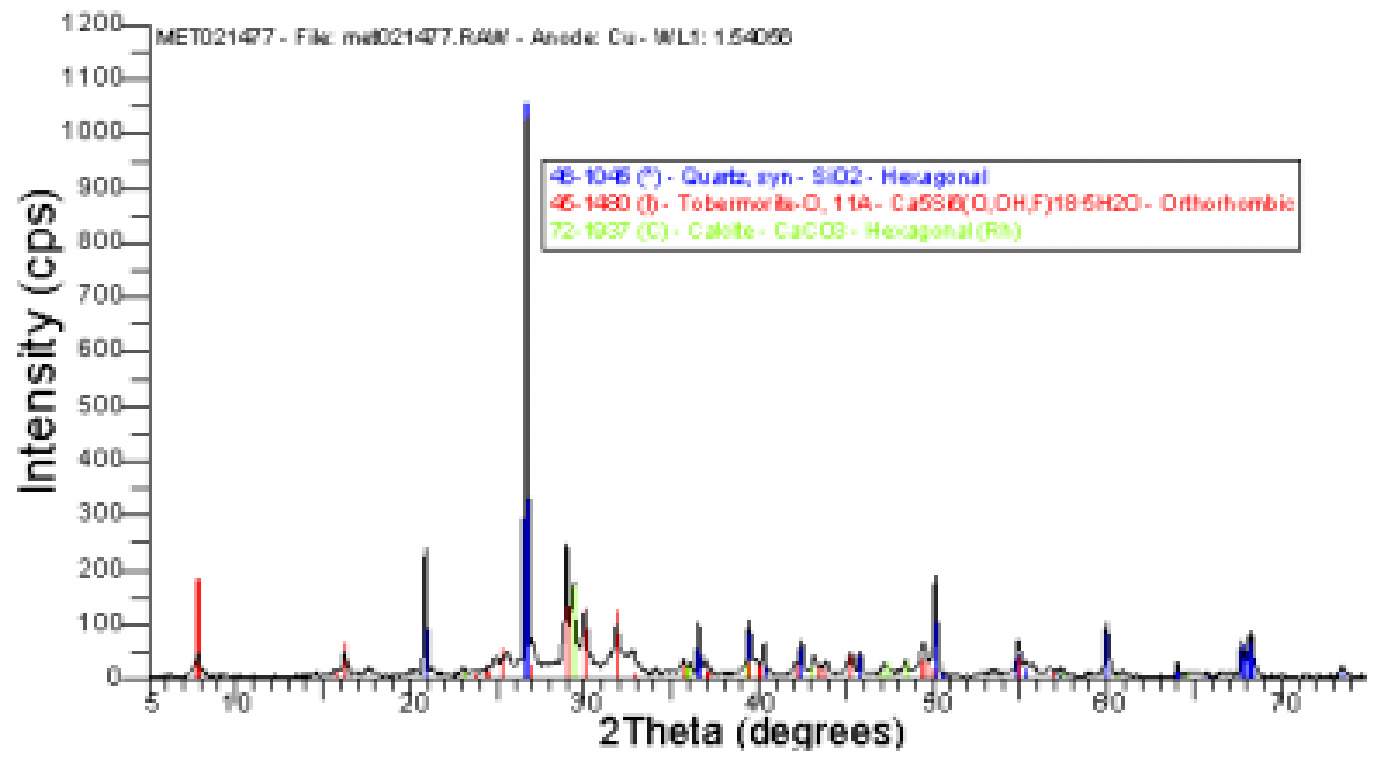

FIGURA 5.3 - Difratograma da amostra de pedra pome. As fases cristalinas identificáveis são: quartzo $\left(\mathrm{SiO}_{2}\right)$, tobermorita $\left[\mathrm{Ca}_{5} \mathrm{Si}_{6}(\mathrm{O}, \mathrm{OH}, \mathrm{F})_{18}-5 \mathrm{H}_{2} \mathrm{O}\right]$ e calcita $\left(\mathrm{CaCO}_{3}\right)$. 


\subsection{Monitoramento do sistema}

O ASBR projetado, construído e operado visando promover o tratamento do esgoto sanitário para remoção da matéria orgânica, com utilização da pedra pome sintética como material suporte, foi monitorado para acompanhar a variação de diversos parâmetros, como: $\mathrm{pH}$, temperatura externa, alcalinidade a bicarbonato (AB), ácidos voláteis totais (AVT), demanda química de oxigênio (DQO), na forma total, filtrada em membrana de 1,2 $\mu \mathrm{m}$ e $0,45 \mu \mathrm{m}$ e análises de sólidos.

A operação do sistema se estendeu por 86 dias, compreendendo os meses de setembro a dezembro. Foram monitorados 195 ciclos, sendo que, do $1^{\circ}$ ao $12^{\circ}$ ciclo, o tempo total da batelada foi de 24 horas; do $13^{\circ}$ ao $26^{\circ}$, de 12 horas; e do $26^{\circ}$ ao $195^{\circ}$, de 8 horas. $\mathrm{O}$ reator foi mantido sob agitação permanente de $300 \mathrm{rpm}$ a partir do $28^{\circ}$ ciclo.

As condições climáticas foram acompanhadas durante a operação do sistema. $\mathrm{O}$ clima permaneceu quente durante todo o período de monitoramento, com temperatura média máxima de $32 \pm 3^{\circ} \mathrm{C}$ e mínima de $22 \pm 3^{\circ} \mathrm{C}$. Em diversos dias do período, ocorreram chuvas que provocaram diluição da concentração de esgoto sanitário.

Os valores apresentados na FIGURA 5.4 permitem constatar que o pH se manteve relativamente constante, sem sofrer grandes oscilações durante os $195^{\circ}$ ciclos monitorados. Foram obtidos valores médios afluente de $6,7 \pm 0,5$ e efluente de $8,0 \pm 0,5$, com elevação de aproximadamente uma unidade. Foi atribuída a essa elevação a presença de hidroxila $\left(\mathrm{OH}^{-}\right)$ liberada na reações do carbonato e bicarbonato em contato com a água, descrita posteriormente. SARTI et al. (2002) que operaram ASBR no tratamento de esgoto sanitário, obtiveram valores de $\mathrm{pH}$ efluente na faixa de 6,9 a 7,3. 


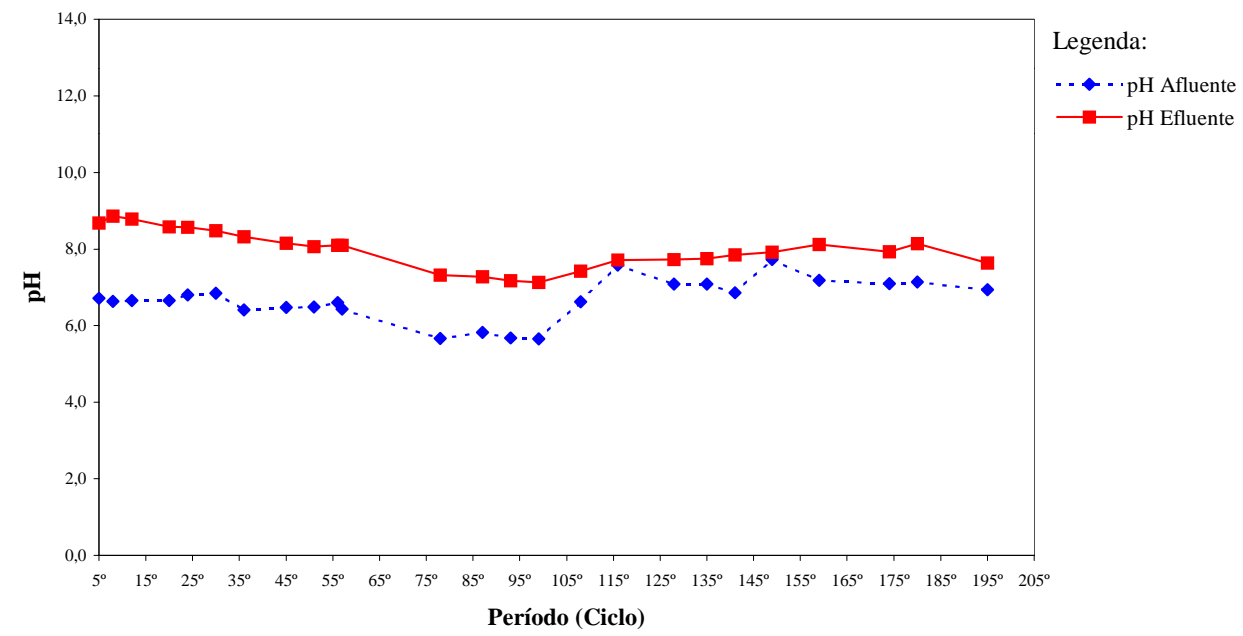

FIGURA 5.4 - Variação do pH no afluente e efluente, durante o período estudado.

A remoção de matéria orgânica do sistema foi monitorada através de análises de demanda química de oxigênio (DQO). Foram obtidos valores de DQO total, particulada, coloidal e solúvel, alguns obtidos diretamente das análises, outros calculados a partir das expressões (2) e (3), esquematizadas na FIGURA 5.5:

$($ DQO particulada $)=($ DQO total $)-($ DQO filtrada $\# 1,2 \mu \mathrm{m})$

$($ DQO coloidal $)=($ DQO filtrada \#1,2 $\mu \mathrm{m})-($ DQO filtrada \#0,45 $\mu \mathrm{m})$

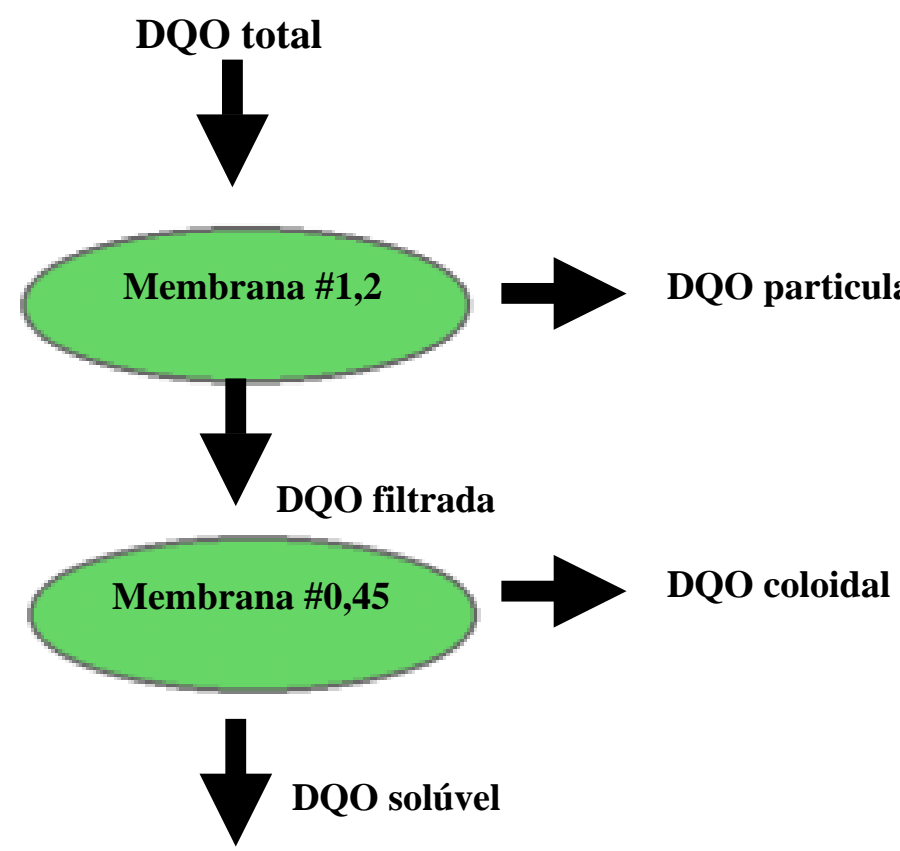

FIGURA 5.5 - Esquema de filtração de DQO para obtenção das frações particuladas, coloidais e solúveis. 
O valor médio obtido para DQO total afluente foi $446 \pm 169 \mathrm{mg} / \mathrm{L}$, com máximo de 789 mg/L e mínimo de 217 mg/L. A carga orgânica volumétrica (COV) média tratada por dia, em relação ao volume total do reator, foi de $0,78 \mathrm{~g} / \mathrm{L}$.dia. Considerando-se apenas o volume reacional, a COV média foi de 1,34 g/L.dia. No entanto, devido à grande variação de concentração de matéria orgânica no afluente, foi possível tratar a COV máxima de 1,40 g/L.dia, em relação ao volume útil do reator e 2,0 g/L.dia, em relação ao volume reacional. O reator anaeróbio em batelada seqüencial, em escala piloto, operado por SARTI et al. (2002) foi submetido à COV média de $0,72 \mathrm{~g} / \mathrm{L}$.dia em relação ao volume total do reator. Isso demonstra que os resultados entre esses dois trabalhos são passíveis de comparação, pois o ASBR objeto desta pesquisa, foi construído em escala de bancada e tratou praticamente a mesma COV em relação ao volume total do reator.

Os valores obtidos nas análises de DQO estão apresentados no ANEXO A. Os valores obtidos após o cálculo das frações de DQO, conforme eq. (2) e (3), estão apresentados no ANEXO B. Após o término de cada batelada analisada, o efluente apresentava-se bem clarificado. Os valores médios de DQO total e filtradas a \#1,2 e a \#0,45 $\mu \mathrm{m}$ foram $233 \pm 52,175 \pm 34$ e $141 \pm 32 \mathrm{mg} / \mathrm{L}$, respectivamente. As eficiências médias foram de 48, 61 e $68 \%$ para DQO total e filtradas a \#1,2 e a \#0,45 $\mu$ m, respectivamente. SARTI et al. (2002) observaram que o período de partida foi curto, de aproximadamente 20 dias e que, após 122 dias de operação, o efluente apresentou concentração média de $180 \pm 72$ $\mathrm{mg} / \mathrm{L}$ e $126 \pm 53 \mathrm{mg} / \mathrm{L}$ para DQO total e filtrada, respectivamente.

O gráfico dos valores obtidos nas análises de DQO está apresentado na FIGURA 5.6. À primeira vista parece que os valores de DQO efluente mantiveram-se constantes a partir do $55^{\circ}$ ciclo. Porém, calculando-se o desvio padrão antes e após o $55^{\circ}$ ciclo, não foram encontradas variações significativas que pudessem sustentar a observação visual de estabilidade do sistema a partir do $55^{\circ}$ ciclo. Concluiu-se, portanto, que o reator apresentou- 
se estável em todo o período de operação, pois as pequenas variações da DQO efluente foram decorrentes da elevada oscilação da DQO afluente.

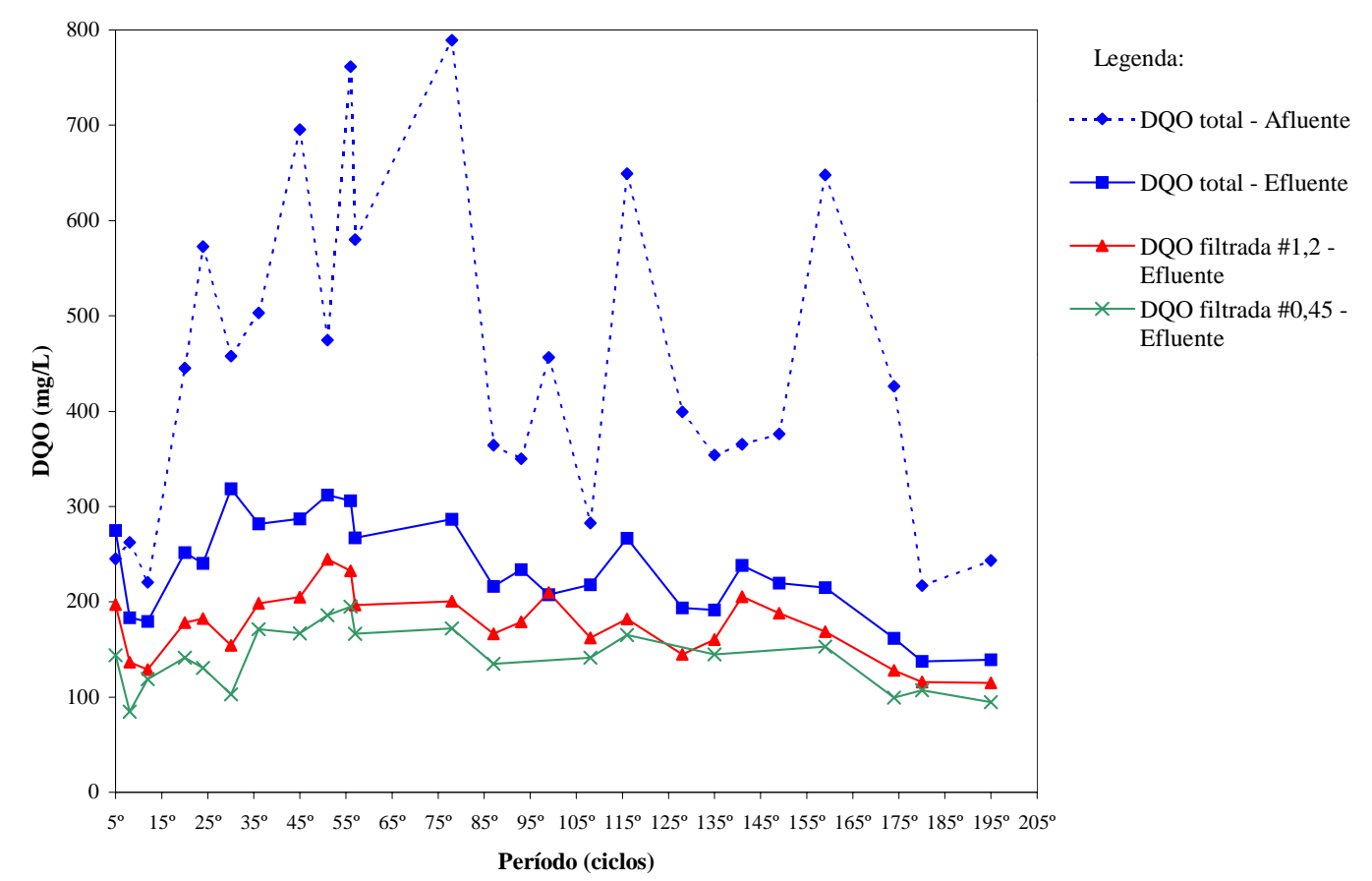

FIGURA 5.6 - Concentração da DQO em amostras totais e filtradas de afluente e efluente.

Na FIGURA 5.7 encontram-se os valores obtidos para a DQO total e fracionada, afluente e efluente. Pode-se observar a estabilidade do reator, pois não ocorreram oscilações significativas dos valores. A maior remoção observada foi para a fração particulada da matéria orgânica, que atingiu valor médio de $64 \pm 31 \mathrm{mg} / \mathrm{L}$ no efluente e eficiência média de 77\%. Porém, para a fração coloidal e solúvel foi observada grande oscilação dos valores, que demonstraram pouca eficiência no processo, quando comparados os valores de entrada e saída. Deve-se considerar, no entanto, que as frações solúvel e coloidal podem resultar, em parte, da digestão da fração particulada. Os resultados obtidos estão descritos no ANEXO B. 


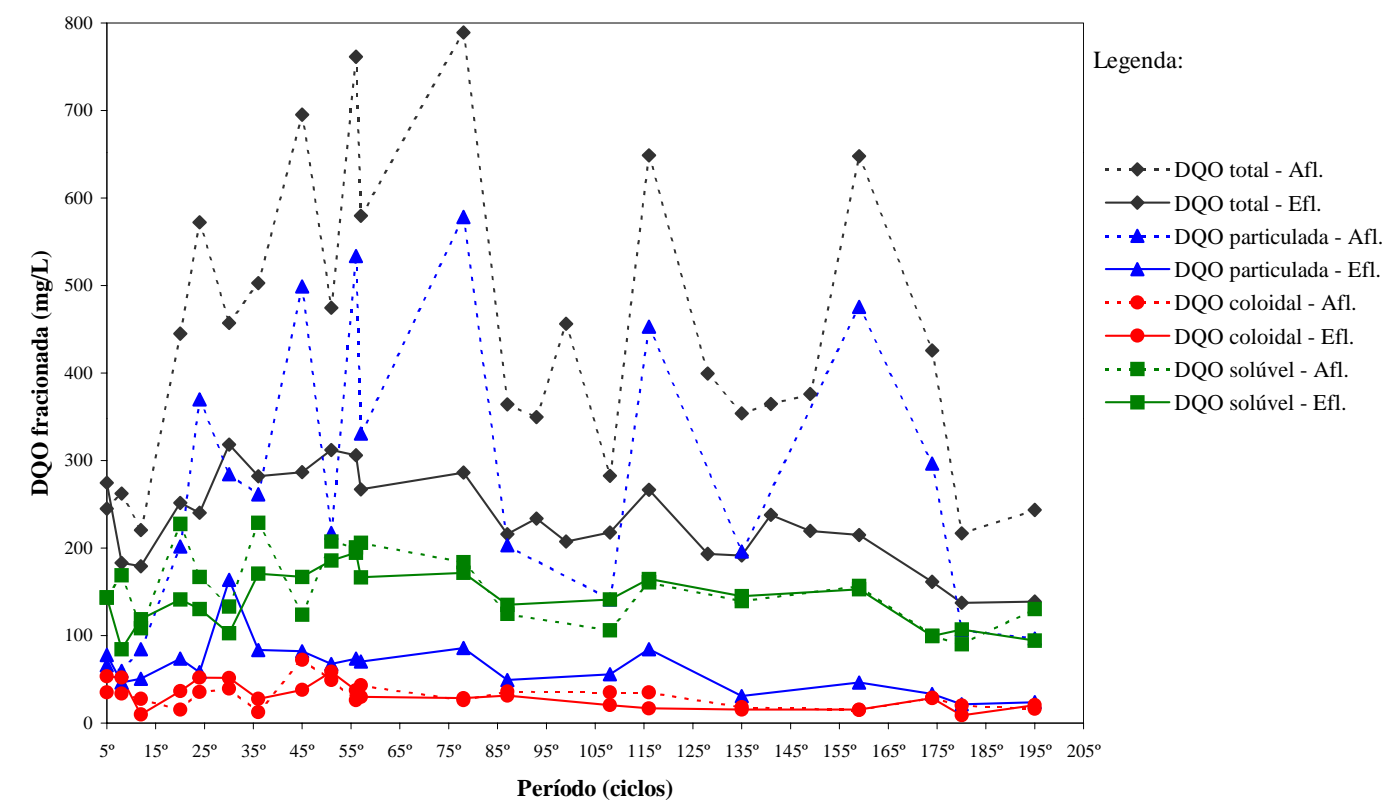

FIGURA 5.7 - Concentrações de DQO fracionada em total, particulada, coloidal e solúvel, durante o período estudado.

Foi obtido efluente com concentração média de DQO, das frações particulada, coloidal e solúvel de $64 \pm 31,32 \pm 15$ e $141 \pm 32 \mathrm{mg} / \mathrm{L}$, respectivamente, em relação a DQO média total de $446 \pm 169 \mathrm{mg} / \mathrm{L}$.

As eficiências de remoção da matéria orgânica fracionada, medida em termos de DQO, em relação à entrada e saída, podem ser visualizadas na FIGURA 5.8. Pode-se confirmar graficamente que a maior parcela de remoção da DQO total foi devida à fração particulada, o que indica ocorrência de limitações na etapa metanogênica do processo. 


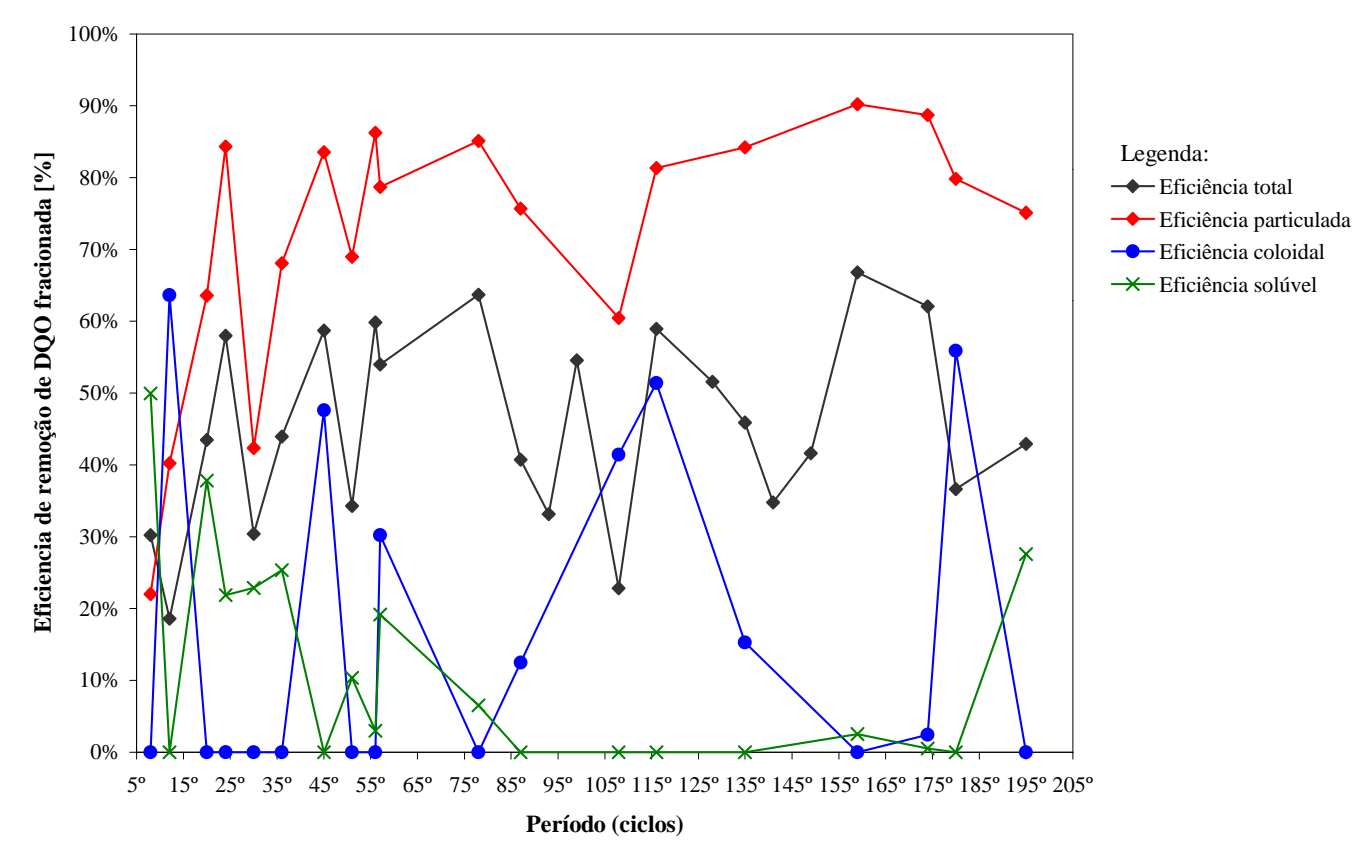

FIGURA 5.8 - Eficiências de remoção de matéria orgânica fracionada durante o período de trabalho.

Os valores de alcalidade a bicarbonato, medidos como $\mathrm{mg} / \mathrm{L}$ de carbonato de cálcio $\left(\mathrm{CaCO}_{3}\right)$, e ácidos voláteis totais, medidos como mg/L de ácido acético $\left(\mathrm{CH}_{3} \mathrm{COOH}\right)$, podem ser vistos no ANEXO C. O reator promoveu alcalinidade, uma vez que a média de alcalinidade a bicarbonato afluente foi de $131 \pm 32 \mathrm{mg} / \mathrm{L}$ e a efluente de $240 \pm 44 \mathrm{mg} / \mathrm{L}, \mathrm{o}$ que corresponde a aumento médio de $82 \%$. A FIGURA 5.9 mostra o comportamento das concentrações obtidos para alcalinidade a bicarbonato durante o monitoramento do reator. As causas para o aumento da alcalinidade podem estar relacionadas à liberação de cálcio do material suporte, discutidas posteriormente.

Os resultados obtidos para as concentrações de ácidos voláteis totais demonstraram que o reator apresentou comportamento regular, com pouca variação dos valores afluentes e efluentes, conforme pode ser visto na FIGURA 5.9. No entanto, os valores efluentes registraram concentrações médias praticamente iguais, considerando o desvio padrão, com médias de $54 \pm 13 \mathrm{mg} / \mathrm{L}$ para AVT afluente e $69 \pm 15 \mathrm{mg} / \mathrm{L}$ para AVT efluente. 
Em sistema anaeróbio é comum a geração de alcalinidade devida às reações que ocorrem no processo. É provável, também, que a fixação de carbonatos devida à reação com cálcio, possa ter tido influência na análise de AVT.

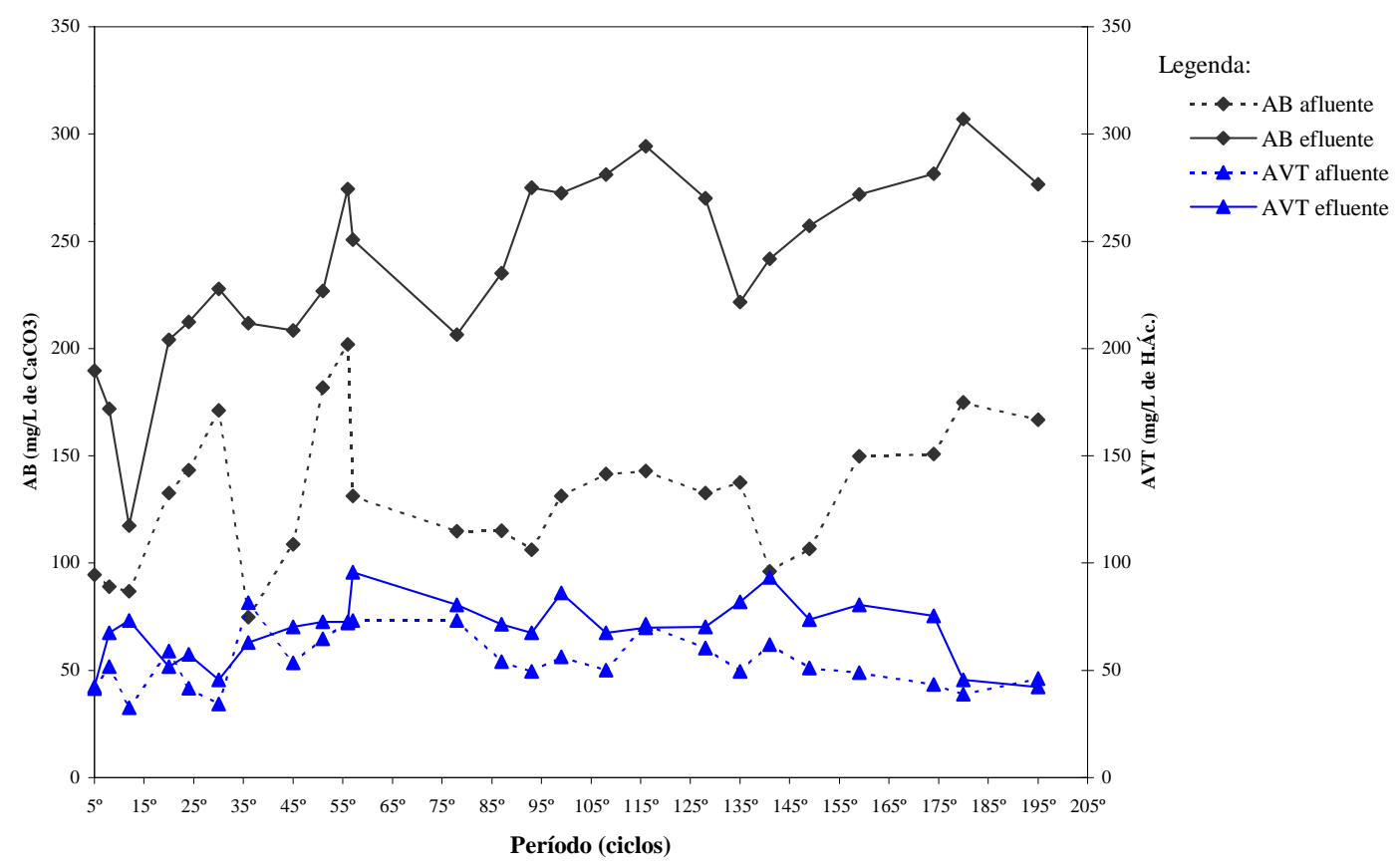

FIGURA 5.9 - Valores de Alcalinidade a bicarbonato e de ácidos voláteis totais durante o período.

Valores obtidos nas análises de monitoramento de sólidos podem ser observados no ANEXO D. Os sólidos totais (ST), totais fixos (STF) e totais voláteis (STV) apresentaram valores médios para o afluente de $599 \pm 173,279 \pm 190$ e $353 \pm 135 \mathrm{mg} / \mathrm{L}$, e para o efluente de $741 \pm 173,399 \pm 164$ e $342 \pm 151 \mathrm{mg} / \mathrm{L}$, respectivamente. Durante todo o período de operação, a redução de ST apresentou oscilações significativas, confirmado pelo grande desvio padrão, conforme demonstrado na FIGURA 5.10. Para os ST, houve aumento da concentração no efluente de $24 \%$, em média; para STV houve pequena redução da concentração no efluente de 3\%, em média. As porcentagens indicam perda de ST e redução mínima de STV. 


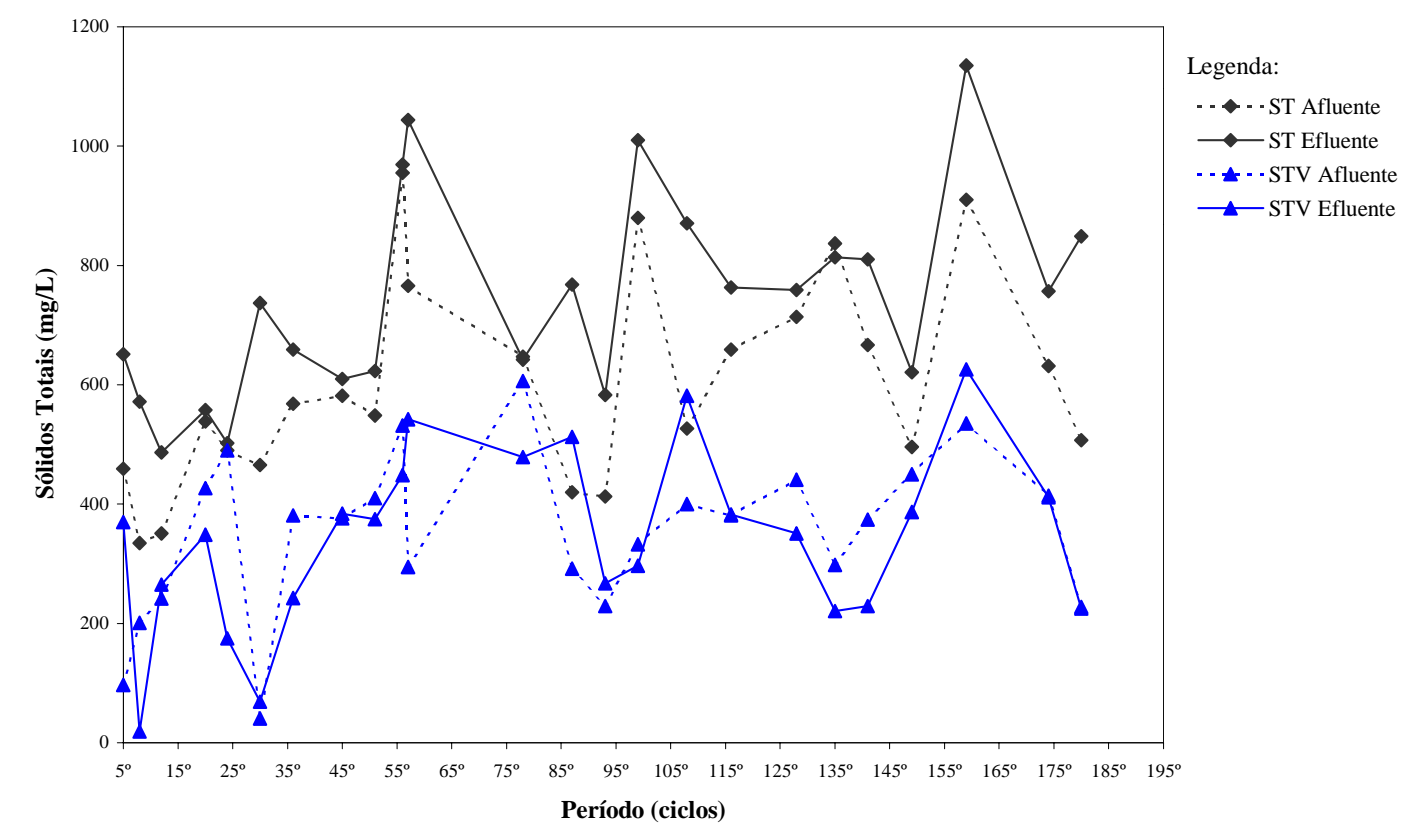

FIGURA 5.10 - Concentração de sólidos totais e sólidos totais voláteis durante o período.

As concentrações de sólidos suspensos apresentaram elevadas reduções, com eficiência média de 70\%. Os valores médios de sólidos suspensos totais (SST), fixos (SSF) e voláteis (SSV) no afluente foram $140 \pm 76,20 \pm 12$ e $120 \pm 64 \mathrm{mg} / \mathrm{L}$ e no efluente de $42 \pm$ $17,6 \pm 14$ e $36 \pm 16 \mathrm{mg} / \mathrm{L}$, respectivamente.

Os resultados apresentados demonstram que a maior parte dos SST estava na forma de SSV. Os sólidos suspensos voláteis fornecem indicação sobre a quantidade de microrganismos presentes no meio. Quanto maior a retenção de SSV no reator, melhor será seu desempenho. $\mathrm{O}$ reator, em toda a operação, manteve relativamente constante a capacidade de redução dos sólidos suspensos, conforme demonstrado pelo baixo desvio padrão no efluente e como observado na FIGURA 5.11. É interessante notar que, mesmo com elevados valores de entrada, o sistema foi capaz de reduzir os sólidos suspensos a seus valores médios.

A análise de SV, neste caso, pode ser utilizada para predizer a quantidade aproximada de biomassa aderida ao material suporte, presumivelmente inerte. Para tanto é feita a separação do biofilme do meio suporte através de lavagem das matrizes. Porém, não 
foi possível realizar essa análise, porque ao lavarem-se as matrizes de pedra pome, as mesmas se desmancharam na forma de material granular, mascarando o resultado.

Também não foi possível utilizar a análise de sólidos voláteis colocando a pedra pome imobilizada na mufla, pois foi observado que, além de volatilizar os sólidos da biomassa, um percentual do material foi perdido. O resultado obtido para sólidos voláteis em relação à pedra pome sem biomassa foi de $23 \mathrm{mg} / \mathrm{cm}^{3}$ e para a pedra pome com biomassa foi de $25 \mathrm{mg} / \mathrm{cm}^{3}$. Mesmo dispondo-se do resultado da análise comparativa da massa de sólidos voláteis da pedra pome sem o biofilme aderido, não foi possível correlacionar os valores, por serem muito próximos.

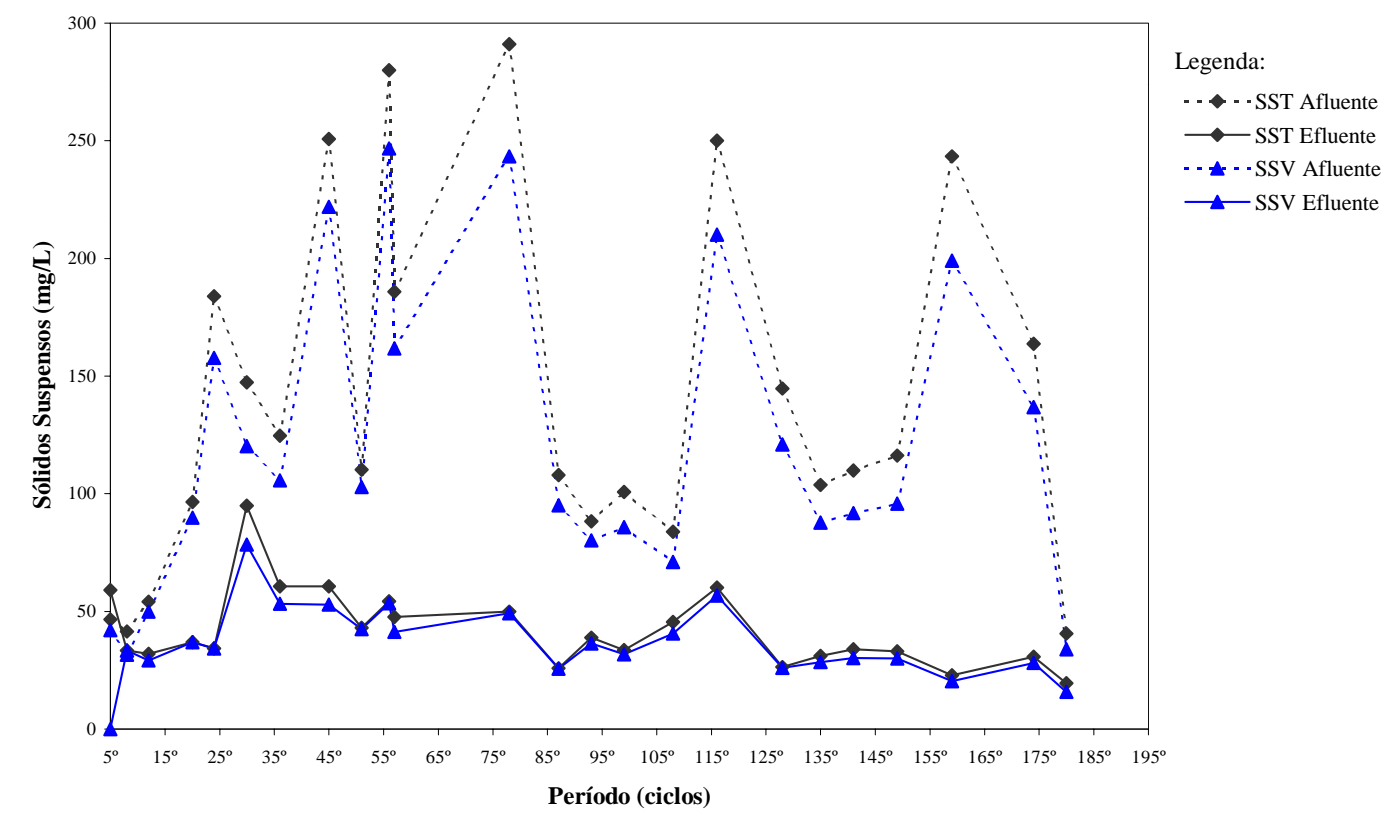

FIGURA 5.11 - Variação das concentrações de sólidos suspensos totais e sólidos suspensos voláteis no monitoramento do reator.

Os sólidos dissolvidos apresentaram efluente com concentração bem mais elevada que o afluente. Os valores médios de sólidos dissolvidos totais (SDT), fixos (SDF) e voláteis (SDV) no afluente foram de $469 \pm 160,256 \pm 151$ e $249 \pm 87 \mathrm{mg} / \mathrm{L}$, e no efluente de $699 \pm$ $176,393 \pm 166$ e $335 \pm 124 \mathrm{mg} / \mathrm{L}$, respectivamente. O percentual de aumento entre as concentrações do afluente para o efluente foram de 49, 53, 34\% para SDT, SDF e SDV, respectivamente. 
A observação desse aumento alertou para a verificação de perda de componentes químicos do material suporte adotado, pois, em outros reatores, essas concentrações normalmente são bem inferiores. O gráfico de SDT e SDV apresentado na FIGURA 5.12 demonstra a predominância de valores mais elevados no efluente que no afluente.

Para confirmar essa suposição, foram feitas análises de dureza e teor de cálcio em três momentos da operação, no $108^{\circ}$ ciclo (48 dias), $141^{\circ}$ ciclo (59 dias) e $149^{\circ}$ ciclo (62 dias). Foi seguida a metodologia proposta pelo STANDARD METHODS FOR EXAMINATION OF WATER AND WASTEWATER (1998).

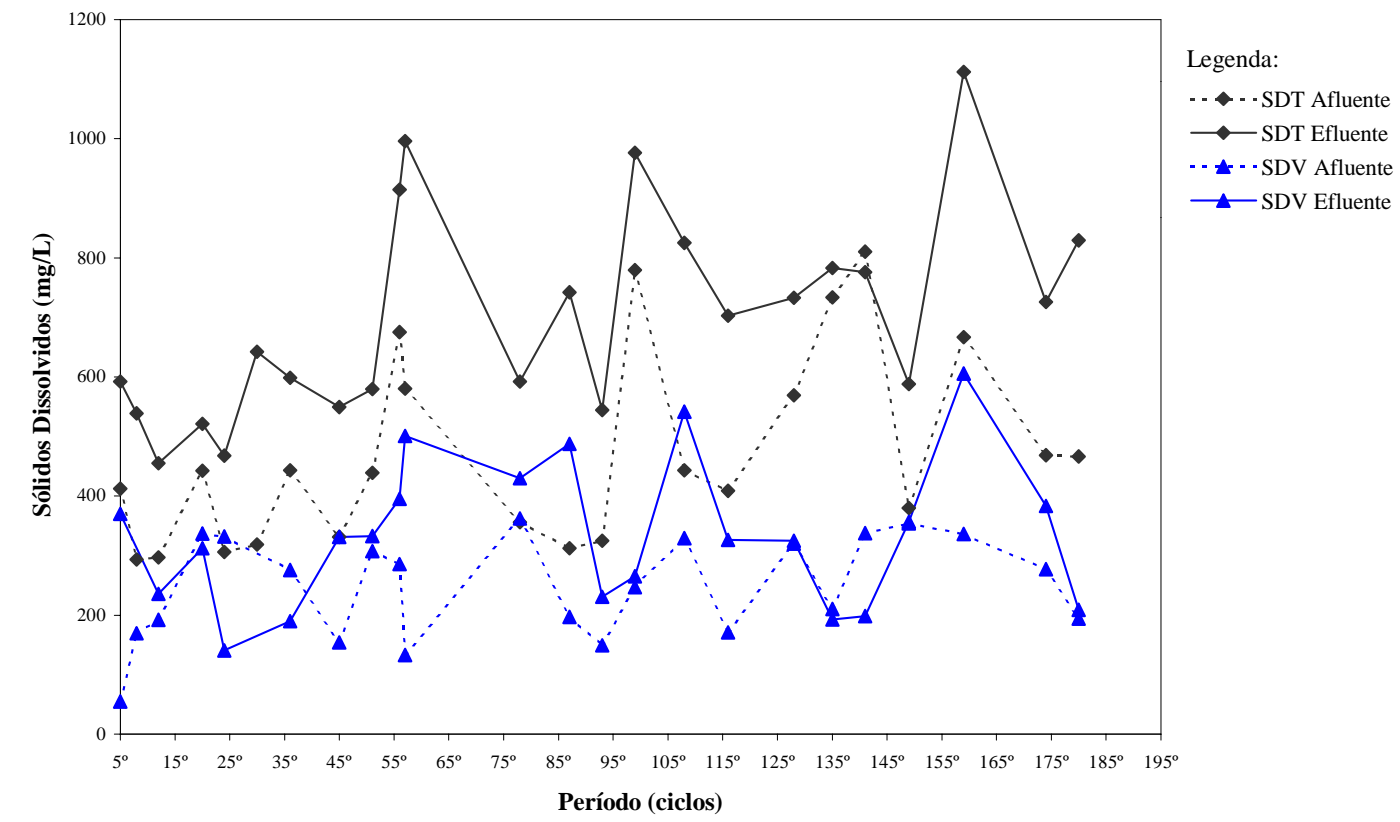

FIGURA 5.12 - Variação das concentrações de sólidos dissolvidos totais e sólidos dissolvidos voláteis no monitoramento do reator.

Os resultados demonstraram que ocorria a perda de cálcio no reator, conforme apresentado na TABELA 5.2, pois o efluente apresentava concentração média de cálcio 259\% maior que a do afluente. Apesar de terem sido analisados apenas três ciclos, é possível dizer que o material suporte perdia, em média, $100 \mathrm{mg} / \mathrm{L}$ de cálcio, na forma de $\mathrm{CaCO}_{3}$.

A densidade aparente da pedra pome, obtida como descrito no item 4.2.4.3, foi de $382 \mathrm{mg} / \mathrm{cm}^{3}$. Como o reator foi preenchido com 2.000 unidades de aproximadamente $1 \mathrm{~cm}^{3}$, 
a massa total aproximada foi de $764 \mathrm{~g}$ de pedra pome. A solubilidade do $\mathrm{CaCO}_{3}$ na água, a $25^{\circ} \mathrm{C}$, é de $0,014 \mathrm{~g} / \mathrm{L}$. Considerada essa solubilidade para cada batelada tratada $(4,2 \mathrm{~L}$ de afluente), o sistema perderia $0,06 \mathrm{~g}$ de $\mathrm{CaCO}_{3}$, ao final das 195 bateladas haveria 11,5 g de $\mathrm{CaCO}_{3}$. Porém, efetuado o mesmo cálculo com a perda média observada nas análises de cálcio, o reator teria perdido $82 \mathrm{~g}$ de $\mathrm{CaCO}_{3}$ ao final das 195 bateladas; ou seja, a perda de cálcio teria sido aproximadamente 6 vezes maior. Essa massa pode ser significativa porque na composição química da pedra pome, determinou-se haver $49 \%$ de cálcio, conforme análise do CCDM, item 5.2. Essa perda observada pode estar relacionada ao ataque da pedra pome sintética por dióxido de carbono $\left(\mathrm{CO}_{2}\right)$ e por ácidos produzidos pelas reações inerentes aos processos anaeróbios.

TABELA 5.2 - Valores obtidos nas análises de dureza e teor de cálcio

\begin{tabular}{|c|c|c|c|c|c|}
\hline \multirow[t]{2}{*}{$\begin{array}{c}\text { Ciclo } \\
\text { analisado }\end{array}$} & \multicolumn{2}{|c|}{$\begin{array}{c}\text { Dureza } \\
\left(\mathrm{mg} / \mathrm{L} \text { de } \mathrm{CaCO}_{3}\right)\end{array}$} & \multicolumn{3}{|c|}{$\begin{array}{c}\text { Cálcio } \\
\left(\mathrm{mg} / \mathrm{L} \mathrm{de} \mathrm{CaCO}_{3}\right)\end{array}$} \\
\hline & Afluente & Efluente & Afluente & Efluente & Efl.-Afl. \\
\hline $108^{\circ}$ & 41 & 155 & 21 & 144 & 123 \\
\hline $141^{\circ}$ & 52 & 157 & 52 & 140 & 88 \\
\hline $149^{\circ}$ & 113 & 177 & 52 & 165 & 113 \\
\hline Média & 69 & 163 & 42 & 150 & 108 \\
\hline $\begin{array}{l}\text { Desvio } \\
\text { Padrão }\end{array}$ & 39 & 12 & 18 & 13 & 18 \\
\hline
\end{tabular}

A perda de cálcio no reator foi detectada pela observação do inesperado aumento, nos processos anaeróbios para tratamento de esgoto sanitário, de três variáveis de monitoramento, o pH, a alcalinidade a bicarbonato e os sólidos dissolvidos.

Para explicar esse fenômeno, recorreu-se a estudos químicos através das análises das equações que seguem (STUMM \& MORGAN, 1924; SNOEYINK \& JENKINS, 1935; QUAGLIANO \& VALLARINO, 1979): 


$$
\begin{aligned}
& \mathrm{CaCO}_{3}+\mathrm{CH}_{3} \mathrm{COOH} \rightleftarrows \mathrm{Ca}^{+2}+\mathrm{HCO}_{3}^{-}+\mathrm{CH}_{3} \mathrm{COO}^{-} \\
& \mathrm{CaO}+\mathrm{H}_{2} \mathrm{O} \rightleftarrows \mathrm{Ca}(\mathrm{OH})_{2} \text { (aq.) } \\
& \mathrm{Ca}(\mathrm{OH})_{2} \text { (aq.) }+2 \mathrm{CO}_{2} \rightleftarrows \mathrm{Ca}^{+2}+2 \mathrm{HCO}_{3}^{-} \\
& \mathrm{CO}_{2}+\mathrm{H}_{2} \mathrm{O} \rightleftarrows \mathrm{H}_{2} \mathrm{CO}_{3} \rightleftarrows \mathrm{H}^{+}+\mathrm{HCO}_{3}^{-} \\
& \mathrm{CO}_{3}^{-}+\mathrm{H}_{2} \mathrm{O} \rightleftarrows \mathrm{HCO}_{3}^{-}+\mathrm{OH}^{-} \\
& \mathrm{HCO}_{3}^{-}+\mathrm{H}_{2} \mathrm{O} \rightleftarrows \mathrm{H}_{2} \mathrm{CO}_{3}+\mathrm{OH}^{-}
\end{aligned}
$$

$\mathrm{Na}$ presença de ácidos fracos o $\mathrm{CaCO}_{3}$ torna-se solúvel, desprendendo dióxido de carbono $\left(\mathrm{CO}_{2}\right)$ (QUAGLIANO \& VALLARINO, 1979). Nos processos anaeróbios os ácidos voláteis totais, medidos como $\mathrm{CH}_{3} \mathrm{COOH}$, em contado com $\mathrm{CaCO}_{3}$ formam, entre outros, acetato $\left(\mathrm{CH}_{3} \mathrm{COO}^{-}\right)$, bicarbonato $\left(\mathrm{HCO}_{3}^{-}\right)$e liberam íon cálcio $\left(\mathrm{Ca}^{+2}\right)$, conforme eq. (4). Além disso, um dos componentes da pedra pome sintética é a cal $(\mathrm{CaO})$, que em meio aquoso torna-se hidróxido de cálcio $\left(\mathrm{Ca}(\mathrm{OH})_{2}\right)$, que também forma bicarbonato e libera íon cálcio, conforme eq. (5) e (6).

$\mathrm{O}$ gás carbônico dissolvido na água pode formar o ácido carbônico $\left(\mathrm{H}_{2} \mathrm{CO}_{3}\right)$, um ácido fraco que pode se decompor em prótons $\left(\mathrm{H}^{+}\right)$e $\mathrm{HCO}_{3}^{-}$, conforme eq. (7). Já o íon carbonato em contato com a água pode formar bicarbonato e liberar a hidroxila $\left(\mathrm{OH}^{-}\right)$, conforme a eq. (8). Assim como, a presença de íons bicarbonato na água pode formar ácido carbônico e liberar hidroxila, conforme eq. (9).

Com essas equações pode-se explicar o que ocorreu durante o monitoramento do reator. $\mathrm{O}$ aumento excessivo da alcalinidade a bicarbonato provavelmente foi devido a presença de bicarbonato, gerado pelas reações químicas descritas nas eq. (4) a (9). As hidroxilas liberadas pela ocorrência das reações descritas nas eq. (8) e (9) provavelmente foram as causadoras do aumento do $\mathrm{pH}$, ficando próximo a 8,0. Por fim, a presença de íons 
cálcio no meio líquido aumentaram a dureza e fizeram com que aumentasse a concentração de sólidos dissolvidos no efluente.

Esses estudos permitiram concluir que o carbonato de cálcio continuaria se dissolvendo no meio líquido, pois se promoviam três bateladas diárias no reator. Isso estava causando a desestruturação da pedra pome, que, provavelmente, perderia componentes químicos até sua total desagregação.

\subsection{Perfis temporais realizados no final da operação}

O reator foi considerado em equilíbrio logo no primeiro mês de operação. No entanto, foi necessário operar por mais dois meses a fim de se garantir essa condição, pois o esgoto sanitário apresentava concentração de matéria orgânica variável no decorrer dos dias, inclusive ao longo do dia e a observação de perda constante de sólidos no reator poderia indicar que o mesmo ainda encontrava-se no período de partida. Assim, no $198^{\circ}$ ciclo, foi realizado perfil de alcalinidade a bicarbonato $(\mathrm{AB})$ e ácidos voláteis totais (AVT). No ciclo 201 foi realizado perfil de pH e DQO, nas suas diversas frações e no ciclo 204 foi realizado perfil de potencial de oxi-redução (POR). Os resultados obtidos para todos os perfis constam no ANEXO E.

Os dados de perfil foram obtidos durante o tempo de ciclo de 8 horas. A primeira coleta correspondeu ao afluente que efetivamente entrou no sistema. A segunda, aconteceu aos 11 minutos, ou seja, um minuto após o término do tempo de enchimento. Esse valor foi obtido após mistura com o volume de líquido remanescente da batelada anterior. As 5 coletas seguintes foram tomados a cada 15 minutos, outras 8 a cada 30 minutos e as 2 finais a cada hora, com total de 17 coletas.

A FIGURA 5.13 mostra os valores obtidos no perfil temporal de $\mathrm{pH}$ e POR. O pH não sofreu grande alteração durante todo o tempo de reação. $\mathrm{O}$ valor de entrada foi de 7,3 e, após o período de enchimento, quando o afluente se mistura ao líquido remanescente da 
batelada anterior, o pH atingiu o valor de 7,5. Após duas horas de reação o pH manteve-se aproximadamente constante em 7,7.

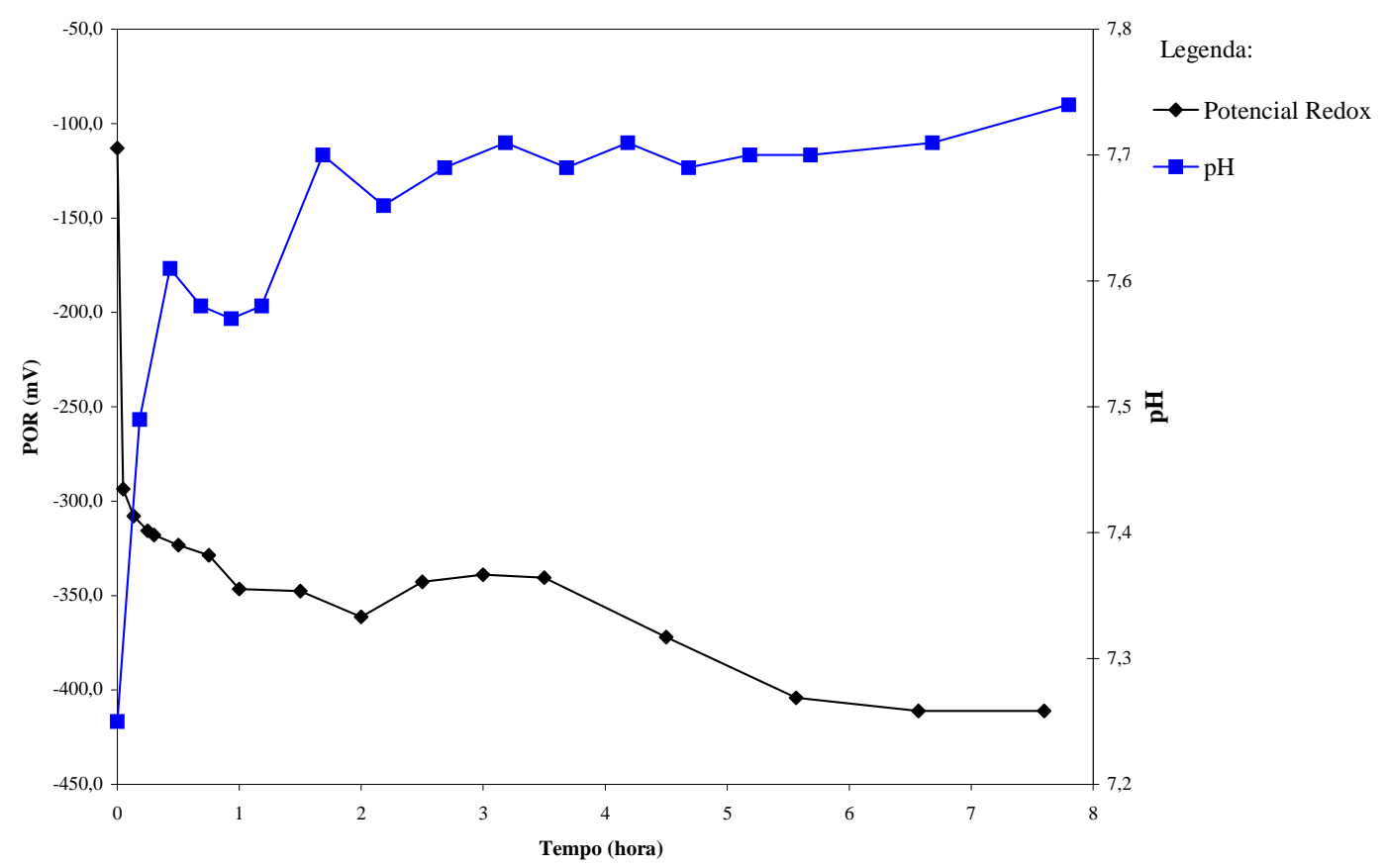

FIGURA 5.13 - Perfis temporais de pH e de potencial de oxi-redução.

Segundo BISHOP \& YU (1999), o POR é indicativo da tendência de um determinado sistema doar ou receber elétrons, tornando-se oxidado ou reduzido. Em sistemas microbianos, o POR é primariamente determinado pelo rendimento energético das reações nas células bacterianas, sendo um parâmetro associado com a dinâmica do processo.

Os valores medidos de POR, durante o perfil temporal, demonstraram que o reator operou em regime anaeróbio. O POR de entrada foi de $-113 \mathrm{mV}$ e decaiu bruscamente nos primeiros 11 minutos para aproximadamente $-300 \mathrm{mV}$. Após 1 hora o reator passou a operar a $-350 \mathrm{mV}$ e, nas últimas 3 horas, a $-400 \mathrm{mV}$. Na literatura estudada por HARPER \& POHLAND (1986), reatores metanogênicos apresentaram POR de -354 a $-400 \mathrm{mV}$ para substrato de lodo de esgoto acidificado, $-530 \mathrm{mV}$ para lodo de esgoto e $-370 \mathrm{mV}$ para chorume de aterro sanitário. Portanto, as medidas de POR indicam que o processo metanogênico poderia estar bem estabelecido no reator. 
Os perfis de DQO total e filtrada nas membranas 1,2 e 0,45 $\mu$ m estão apresentados na FIGURA 5.14. Pode ser observado que a DQO total apresentou variação típica à de reator em batelada (CUBAS et al., 2002; PINHO et al., 2002; SARTI et al., 2002). O valor da DQO afluente foi de $466 \mathrm{mg} / \mathrm{L}$ e após completado o tempo de enchimento (10 minutos), o valor passou para $343 \mathrm{mg} / \mathrm{L}$, devido à diluição anteriormente mencionada, com residual de $169 \mathrm{mg} / \mathrm{L}$. Observou-se que decorridas 4 horas, o efluente já apresentava esse valor. Isso pode sugerir que o tempo de ciclo pode ser reduzido para 4 horas em cada batelada.

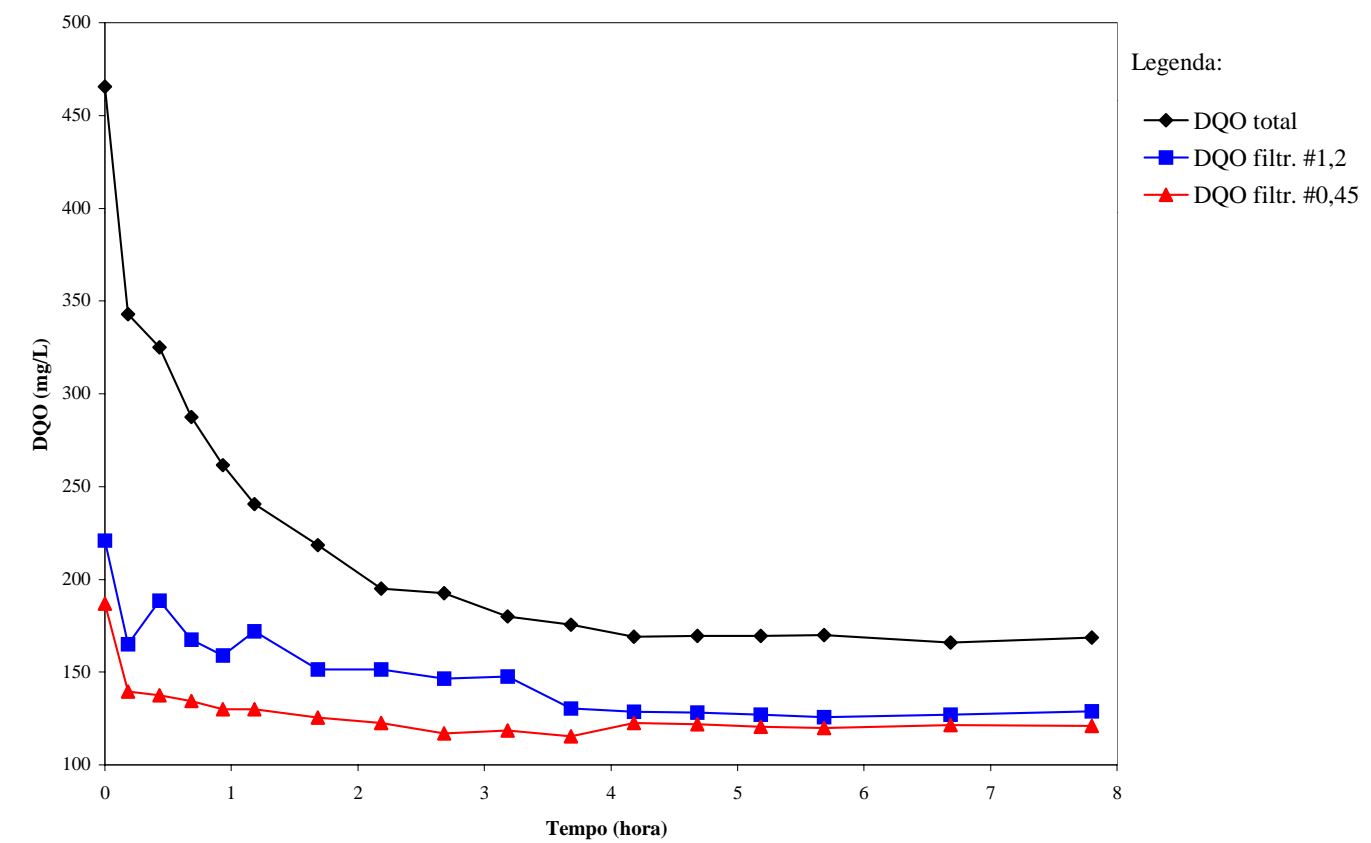

FIGURA 5.14 - Perfil temporal de demanda química de oxigênio total, filtrada \#1,2 e filtrada \#0,45.

RATUSZNEI et al. (2000) observaram que a eficiência máxima de remoção de matéria orgânica ocorreu após 3 horas de tempo de ciclo. Porém é importante relatar que esses autores utilizaram substrato sintético e que o reator foi submetido à agitação mecânica, com agitador magnético, à velocidade de 200 rpm.

Para DQO filtrada na membrana de $1,2 \mu \mathrm{m}$ houve redução da concentração de matéria orgânica, com valor de entrada de $221 \mathrm{mg} / \mathrm{L}$ e saída de $129 \mathrm{mg} / \mathrm{L}$. Para DQO filtrada 
na membrana de $0,45 \mu \mathrm{m}$ houve menor remoção de matéria orgânica, com valor de entrada de $187 \mathrm{mg} / \mathrm{L}$ e saída de $121 \mathrm{mg} / \mathrm{L}$.

A partir dos valores medidos de DQO total e filtrada foi possível determinar os perfis de DQO particulada, coloidal e solúvel, apresentados na FIGURA 5.15. O gráfico demonstra que a maior remoção de matéria orgânica se deu em relação à fração particulada do esgoto sanitário, que assumiu tendência semelhante à da DQO total. Os valores de entrada e saída da fração particulada foram de 245 e $40 \mathrm{mg} / \mathrm{L}$, o que corresponde a eficiência de remoção de, aproximadamente, $84 \%$.

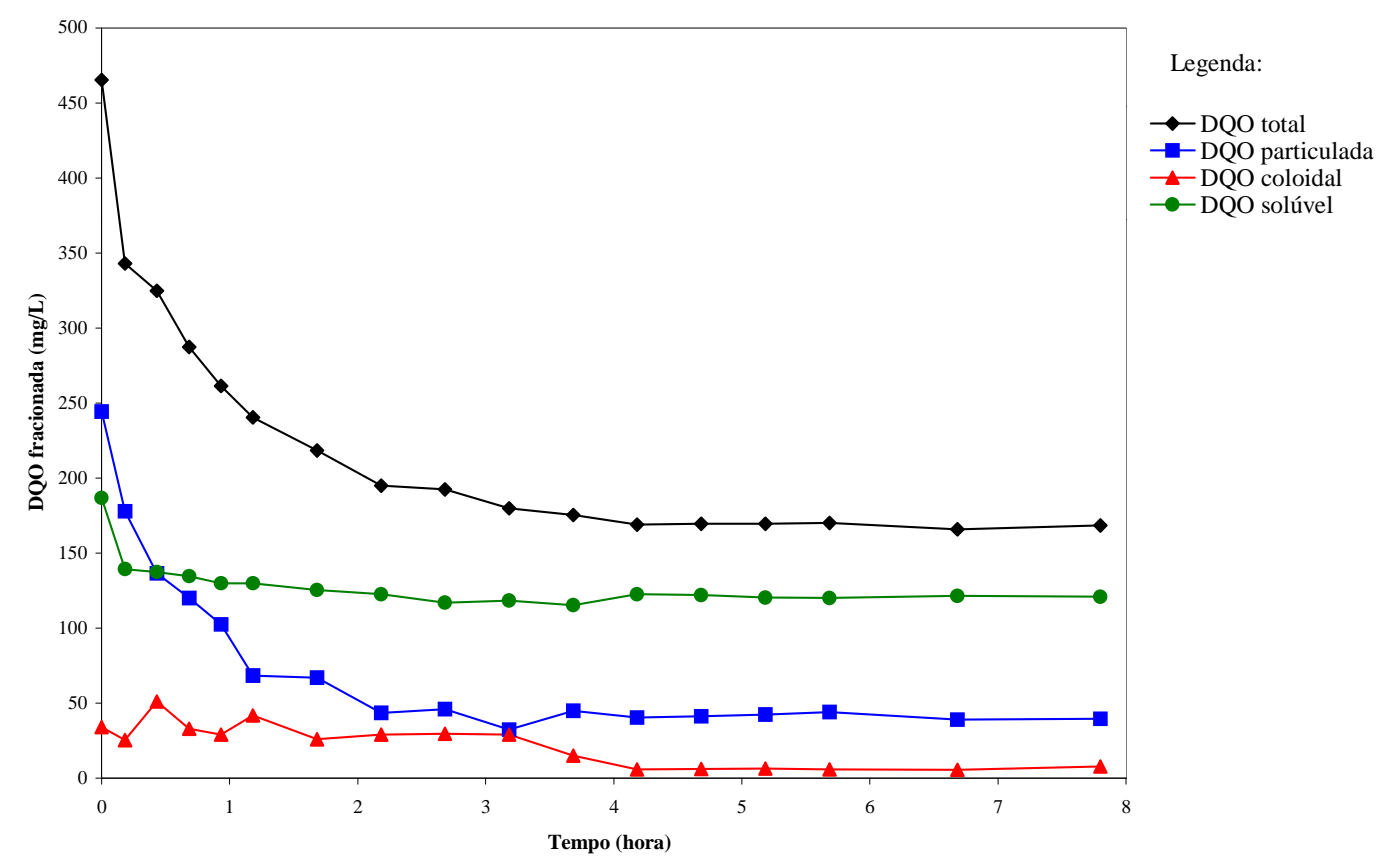

FIGURA 5.15 - Perfil temporal de demanda química de oxigênio na forma de DQO particulada, coloidal e solúvel.

O perfil de DQO solúvel permaneceu praticamente constante durante toda a batelada e para a DQO coloidal houve pequena remoção durante as 4 primeiras horas, permanecendo constante nas 4 horas finais. $\mathrm{O}$ reator demonstrou boa capacidade de tratamento para a fração particulada do esgoto sanitário e muito pouca para as frações coloidal e solúvel.

A FIGURA 5.16 apresenta o gráfico dos perfis temporais para alcalinidade a bicarbonato (AB) e ácidos voláteis totais (AVT). O perfil de $\mathrm{AB}$ apresentou valor de entrada 
de $103 \mathrm{mg} / \mathrm{L}$ e saída de $289 \mathrm{mg} / \mathrm{L}$, o que representa geração de alcalinidade excessiva (181\%) no reator, provavelmente devido à perda de cálcio anteriormente relatada. Nota-se que, nas 4 horas restantes, a $\mathrm{AB}$ manteve-se constante. Isso pode confirmar que a perda elevada de cálcio no reator foi devida ao ataque pelos ácidos gerados nas reações anaeróbias.

Para AVT, o perfil apresentou comportamento pouco variável, com valores de entrada e saída de 49 e $87 \mathrm{mg} / \mathrm{L}$, respectivamente. Porém, provavelmente seria mais favorável se não houvesse esse aumento da concentração de ácidos no sistema, o que indicaria processo anaeróbio mais estável.

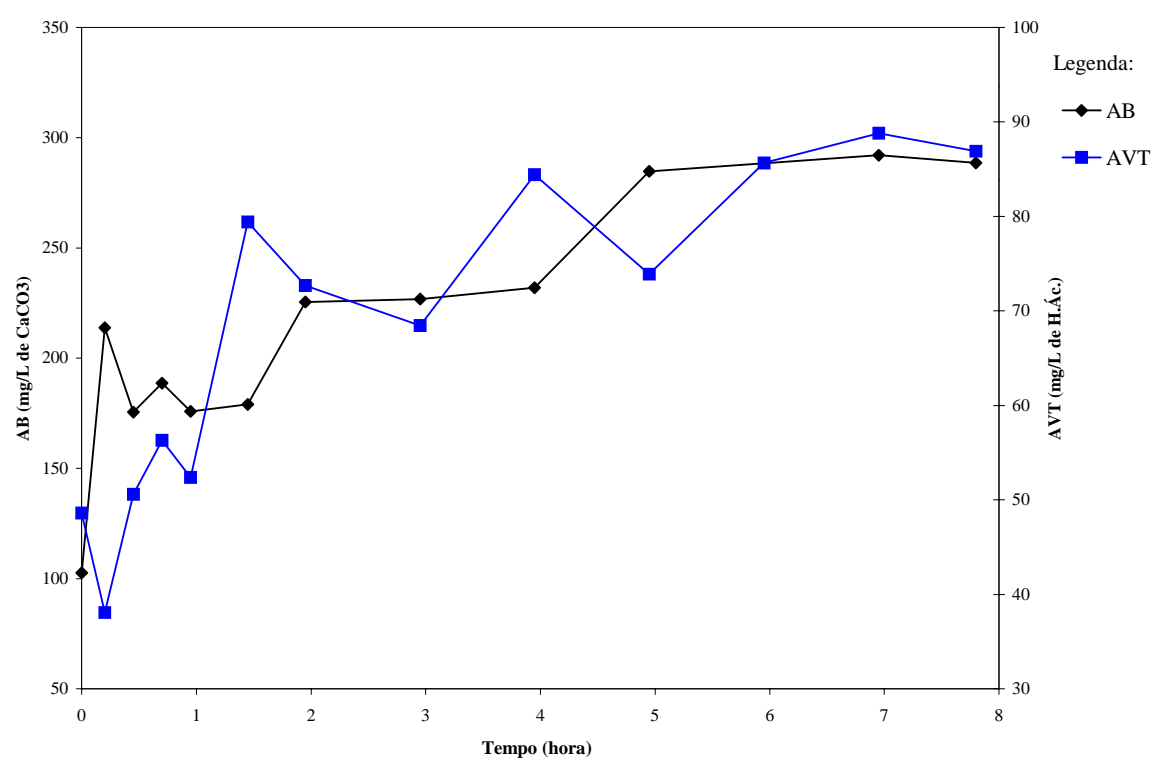

FIGURA 5.16 - Perfil temporal de alcalinidade a bicarbonato e ácidos voláteis totais.

O comportamento geral de todos os perfis indicou que o ASBR operou em condições anaeróbias, com $\mathrm{POR}$ e $\mathrm{pH}$ dentro das faixas encontradas na literatura. O reator promoveu grande remoção de matéria orgânica total, principalmente na forma particulada, com geração de efluente clarificado e praticamente sem odor. 


\subsection{Obtenção de parâmetros cinéticos aparentes}

Os perfis de concentrações de matéria orgânica, medidas através de análises de DQO total e particulada permitiram a obtenção dos parâmetros cinéticos aparentes. Os perfis de DQO coloidal e solúvel não se ajustaram a este modelo, pois dependem do termo de geração da fração particulada da matéria orgânica. O modelo cinético para essas frações dependeria de vários interferentes, os quais não foram estudados nesta pesquisa.

Foi utilizado o método da integral e modelo cinético modificado de primeira ordem, com concentração residual, ajustado por regressão não linear (método de LevenbergMarquardt através do software Origin $6.0^{\circledR}$ ) apresentado por CUBAS et al. (2001) e, também, utilizado por PINHO et al. (2002), cuja expressão é apresentada na eq. (9):

$$
\mathrm{C}_{\mathrm{S}}=\mathrm{C}_{\mathrm{SR}}+\left(\mathrm{C}_{\mathrm{So}}-\mathrm{C}_{\mathrm{SR}}\right) \cdot \mathrm{e}^{-\mathrm{k}_{1}^{\mathrm{ap}} \cdot \mathrm{t}}
$$

Nessa expressão, $\mathrm{C}_{\mathrm{S}}$ é a concentração de substrato no meio líquido (expressa como $\mathrm{DQO}), \mathrm{C}_{\mathrm{So}}$ é a concentração inicial de substrato afluente, $\mathrm{C}_{\mathrm{SR}}$ é a concentração residual no efluente, $\mathrm{k}_{1}^{\text {ap }}$ é a constante cinética aparente de primeira ordem e t é o tempo.

O dados utilizados para o ajuste das curvas compreenderam os valores obtidos após o enchimento completo do reator, ou seja, o primeiro valor obtido nos perfis foi desprezado. Isso foi feito, devido ao efeito da diluição provocada pelo líquido remanescente de cada batelada no fundo do reator.

As curvas ajustadas aos perfis temporais podem ser visualizados na FIGURA 5.17. O modelo cinético representou bem o comportamento do decaimento da concentração de matéria orgânica, medida na forma de DQO total e particulada. 


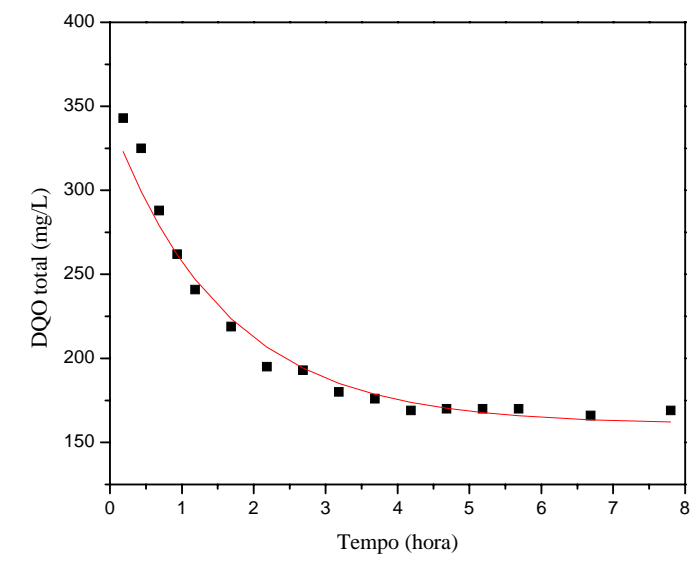

(a)

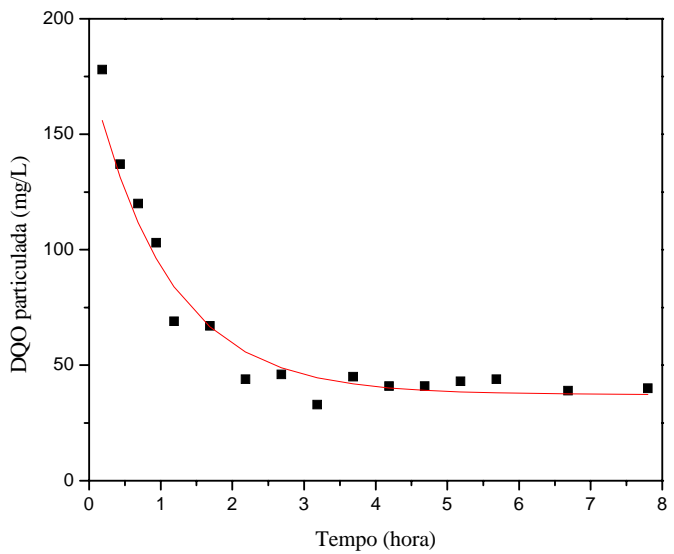

(b)

FIGURA 5.17 - Perfis ajustados para obtenção dos parâmetros cinéticos de (a) DQO total e (b) DQO particulada.

Os resultados numéricos estão apresentados na TABELA 5.3. O coeficiente cinético aparente de primeira ordem para degradação da matéria orgânica total foi $0,63 \pm 0,06 \mathrm{~h}^{-1} \mathrm{e}$ para a particulada $0,93 \pm 0,09 \mathrm{~h}^{-1}$. O melhor ajuste foi para DQO total, com coeficiente de correlação 0,97. Assim como, a velocidade de reação para consumo de substrato foi maior para DQO total do que para DQO particulada.

TABELA 5.3 - Parâmetros do ajuste da expressão de primeira ordem com residual.

\begin{tabular}{c|ccc|}
\hline \multirow{2}{*}{ Parâmetros } & \multirow{2}{*}{ Un. } & \multicolumn{2}{|c|}{ Fração de substrato } \\
\cline { 3 - 4 } & & Total & Particulada \\
\hline $\mathrm{C}_{\mathrm{S} 0}{ }^{(\mathrm{a})}$ & $\mathrm{mg} / \mathrm{L}$ & 343 & 178 \\
$\mathrm{C}_{\mathrm{SR}}{ }^{(\mathrm{b})}$ & $\mathrm{mg} / \mathrm{L}$ & $161 \pm 5$ & $37 \pm 4$ \\
$\mathrm{k}_{1}{ }^{\text {ap (c) }}$ & $\mathrm{h}^{-1}$ & $0,63 \pm 0,06$ & $0,93 \pm 0,09$ \\
$\mathrm{R}^{2(\mathrm{~d})}$ & $* * *$ & 0,97 & 0,96 \\
\hline
\end{tabular}

(a) concentração inicial de substrato $(\mathrm{mg} / \mathrm{L})$; ${ }^{\text {(b) }}$ concentração de substrato residual $(\mathrm{mg} / \mathrm{L})$; ${ }^{(c)}$ coeficiente cinético aparente de primeira ordem $\left(h^{-1}\right) ;{ }^{(d)}$ coeficiente de correlação.

Não é possível fazer a comparação dos parâmetros obtidos, pois a literatura apresenta coeficientes decorrentes de outras condições experimentais como substrato, temperatura, agitação e tamanho de partícula (MASSÉ \& DROSTE (1997); RATUSZNEI et al., 2001; CUBAS et al., 2001 e 2002; PINHO et al., 2002). No entanto, vários autores obtiveram o mesmo comportamento cinético, ou seja, modelo cinético de primeira ordem para descrever 
o decaimento da concentração de matéria orgânica no reator anaeróbio em batelada seqüencial (RATUSZNEI et al., 2001; CUBAS et al., 2001 e 2002; PINHO et al., 2002; RODRIGUES et al., 2003).

\subsection{Caracterização microbiológica do sistema}

\subsubsection{Morfologias encontradas no lodo utilizado como inóculo}

Conforme descrito no item 4.1.4., foi utilizado inóculo proveniente de reator UASB, na forma de lodo granular, tratando água residuária de abatedouro de aves. A coleta desse inóculo ocorreu em julho de 2002, e foi armazenado em geladeira para preservar suas característica microbiológicas.

Foi realizada a caracterização morfológica do lodo através de microscopia ótica de luz comum, contraste de fases e fluorescência. Constatou-se presença de morfologias apresentadas na FIGURA 5.18, como bacilos de diversas dimensões, cocos, bacilos em cadeia, bacilos fluorescentes e organismos semelhantes a Methanosarcina sp. e Methanosaeta sp.

De acordo com os exames realizados, o inóculo utilizado apresentou grande variabilidade morfológica de bactérias e arqueas metanogênicas, sendo adequado para os estudos desenvolvidos nessa pesquisa. 


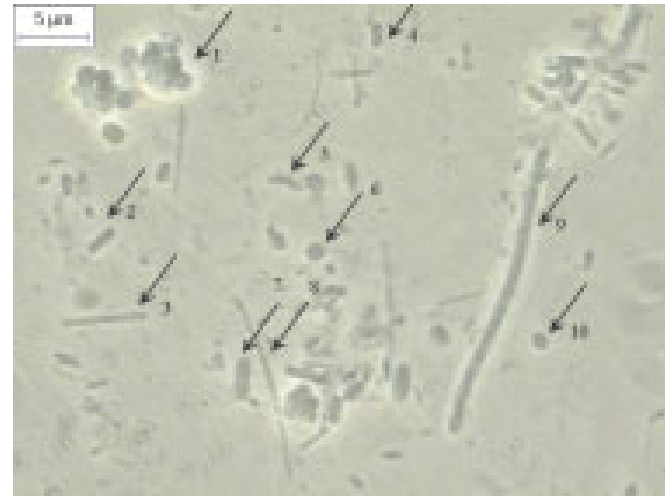

(a)

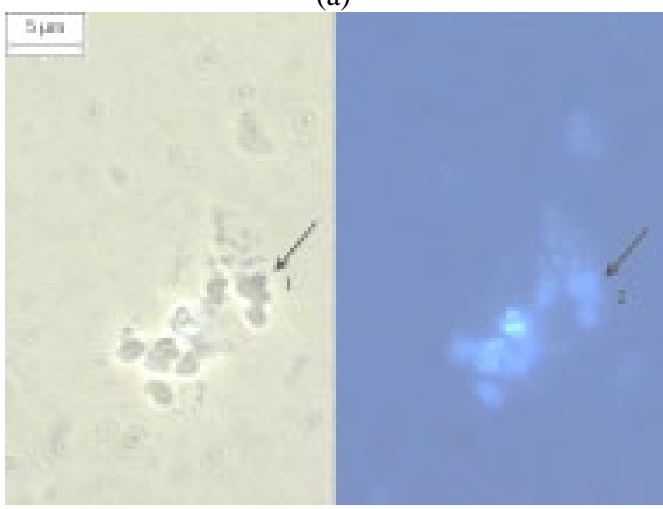

(c)

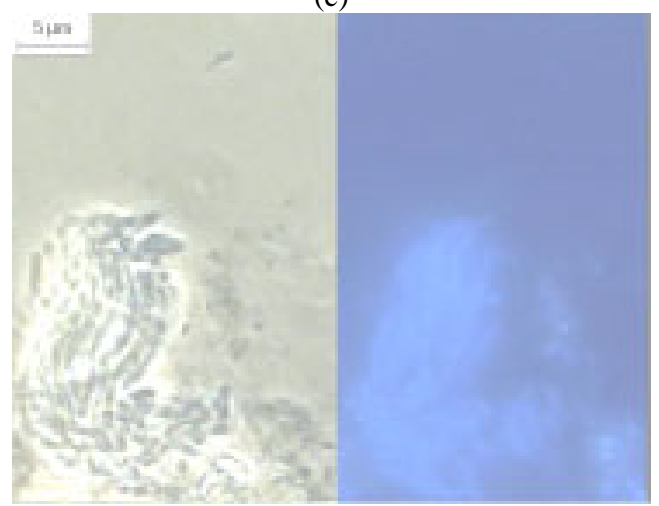

(e)

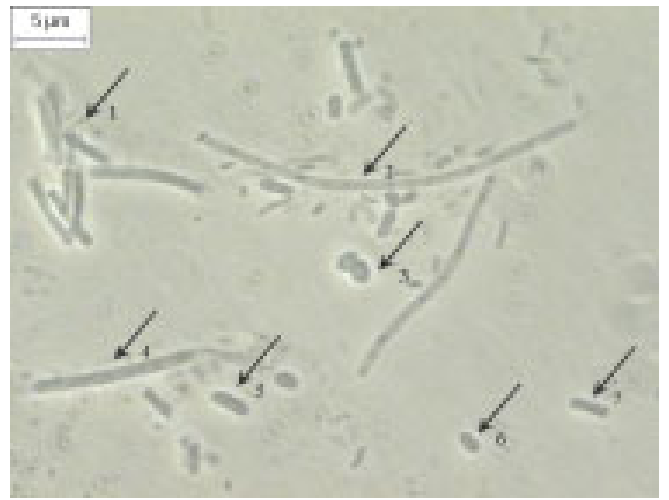

(b)

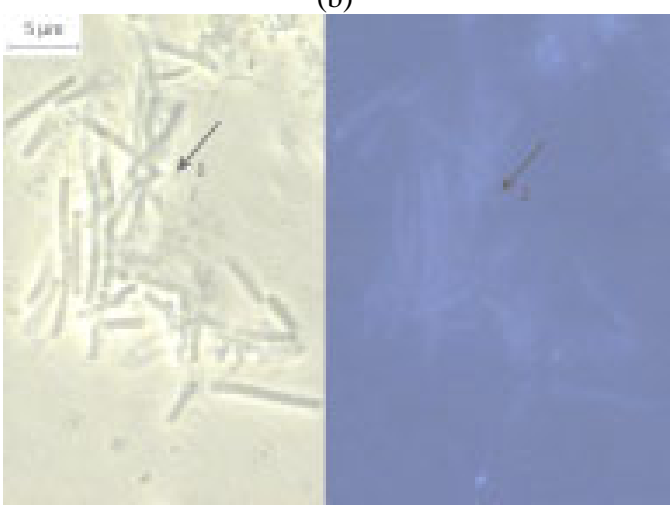

(d)

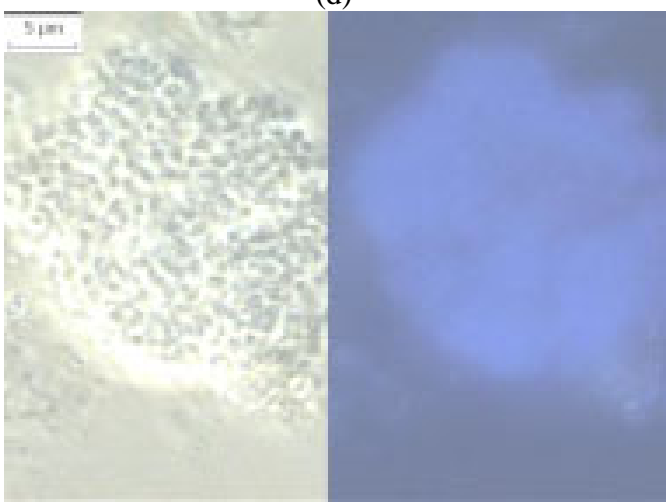

(f)

FIGURA 5.18 - Morfologias presentes no inóculo, através de microscopia ótica, com aumento de 1.250x: (a1) cocos em tétrades; (a6), (a10), (b3) e (b6) cocos; (a2) bacilos retos; (a3) e (b4) bacilos alongados; (b1) bacilos em cadeia; (a4), (a7) e (b5) bacilos com extremidades arredondadas; (a5) víbrio; (a8) filamento; (a9) e (b2) microrganismos semelhantes a Methanosaeta sp.; (c1) e (c2) cocos fluorescentes; (d) bacilos fluorescentes; (e) e (f) microrganismos semelhantes a cistos de Methanosarcinas sp. 


\subsubsection{Morfologias encontradas no material suporte}

O propósito inicial do estudo era realizar as análises de microscopia somente no final da operação. Porém, ao ser detectada perda de sólidos com elevada concentração de cálcio, foram realizados exames de algumas matrizes de material suporte da superfície do cesto de imobilização, a fim de não alterar o ambiente de tratamento. Também foi analisada a camada de lodo que se formou acima da tampa do cesto e que coincidia com o nível máximo de esgoto sanitário no ASBR. No final da operação, 86 dias (216 ciclos), foram retiradas amostras de pedra pome imobilizada de diversos pontos no reator e foram submetidas a exame de microscopia ótica e eletrônica de varredura.

\subsubsection{Morfologias presentes no material suporte aos 62 dias de operação}

Com 62 dias de operação (149 ciclos) o reator foi aberto para coleta de amostras. As morfologias presentes no material suporte podem ser visualizadas na FIGURA 5.19. Predominaram diversas dimensões de bacilos e foram pouco freqüentes alguns víbrios, espiroquetas, bacilos fluorescentes metanogênicos, microrganismos semelhantes a Methanosarcina sp., filamentos com inclusões de enxofre e bacilos alongados com inclusões de enxofre, assim como, microrganismos semelhantes à células fotoanoxigênicas.

As morfologias encontradas nessa fase foram compatíveis com a maioria encontrada no lodo de inóculo. Algumas formas se desenvolveram no reator, devido a grande diversidade microbiana presente no esgoto sanitário, que representa substrato rico em diversos compostos utilizados pelos microrganismos. Essa hipótese é confirmada por RIBEIRO (2001) que observou maior diversidade morfológica na condição com esgoto sanitário sintético.

Houve dificuldade para separar os microrganismos do material suporte, pois as lâminas apresentaram grande quantidade de material inerte, o que dificultou a observação das células. 


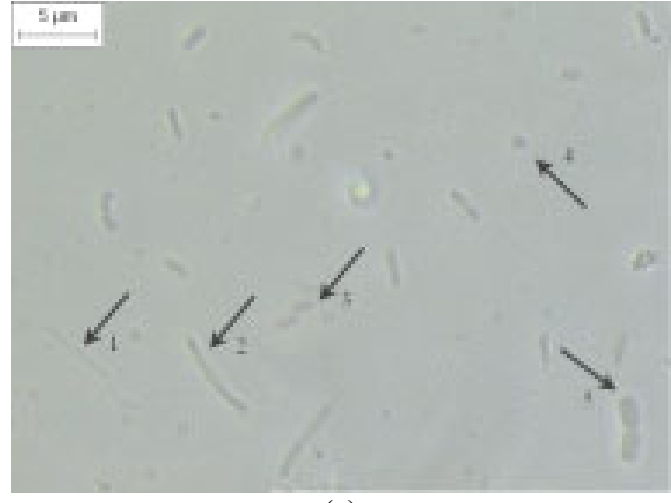

(a)

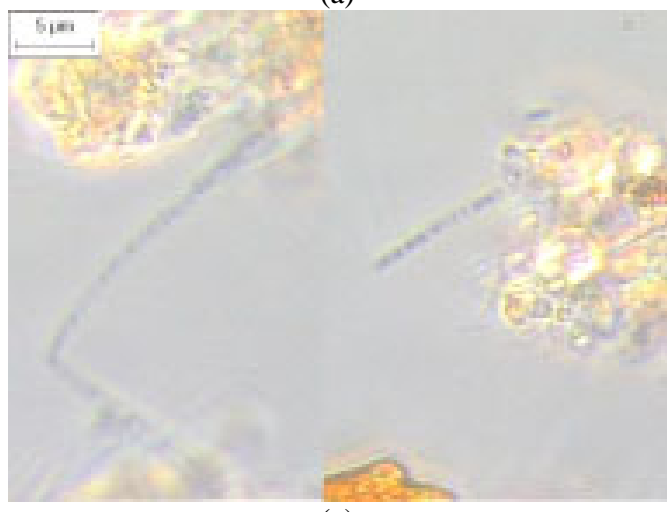

(c)

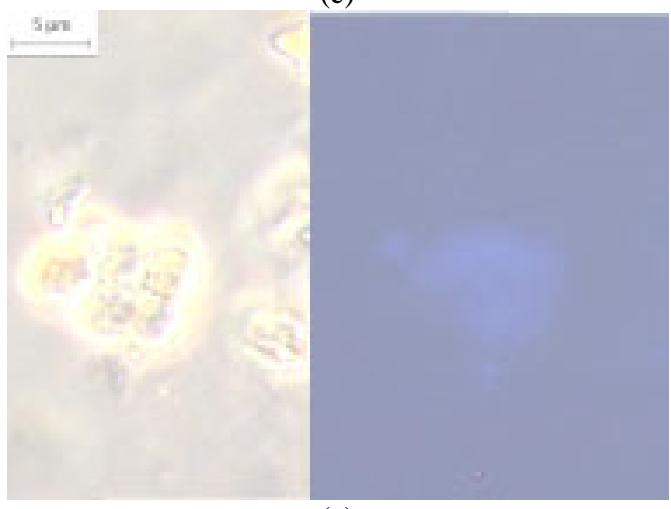

(e)

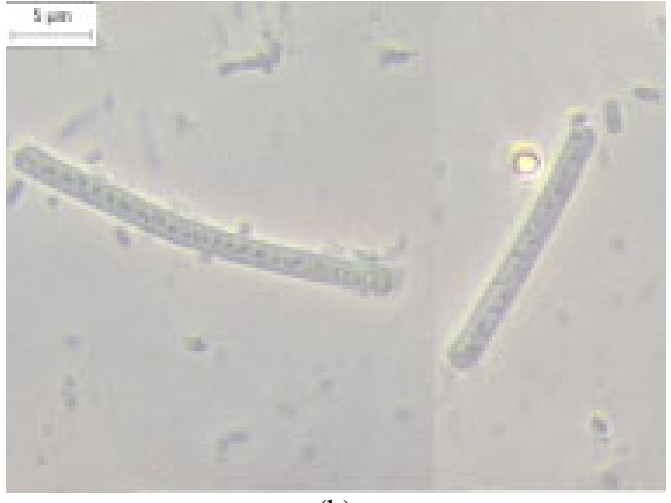

(b)

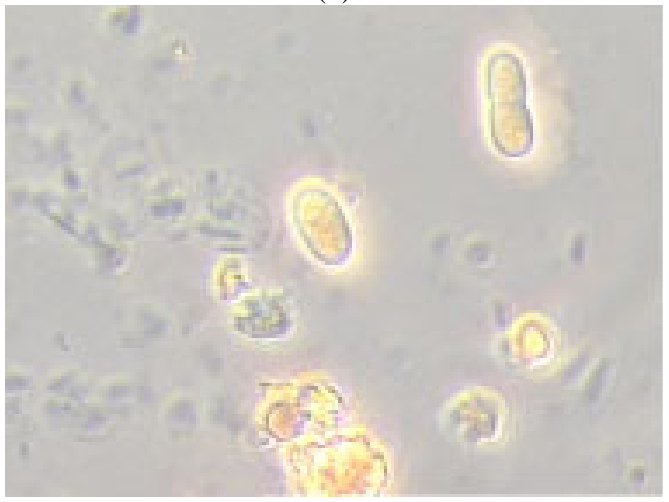

(d)

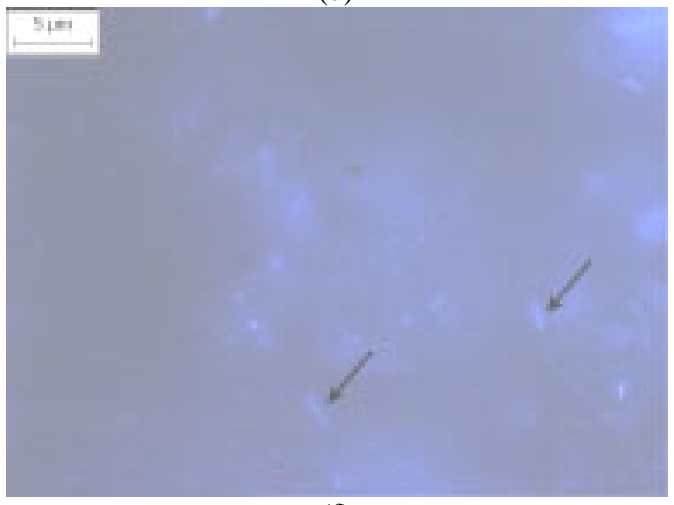

(f)

FIGURA 5.19 - Morfologias presentes no material suporte aos 62 dias de operação (149 ciclos), através de microscopia ótica, com aumento de 1.500x, semelhantes a: (a1) espiroqueta; (a2) filamento; (a3) bacilos com extremidades arredondadas; (a4) cocos; (a5) bacilos ovalados; (b) bacilos alongados com inclusões; (c) filamentos com inclusões; (d) célula fotoanoxigênica; (e) microrganismos semelhantes a Methanosarcinas sp.; (f) bacilos fluorescentes.

A observação das morfologias presentes na amostra através de microscopia eletrônica de varredura foi bastante dificultada pela pouca quantidade de células aderidas. As melhores imagens obtidas estão apresentadas na FIGURA 5.20, com morfologias de diversos tipos de bacilos, cocos e microrganismo semelhante a Methanosarcina sp. 


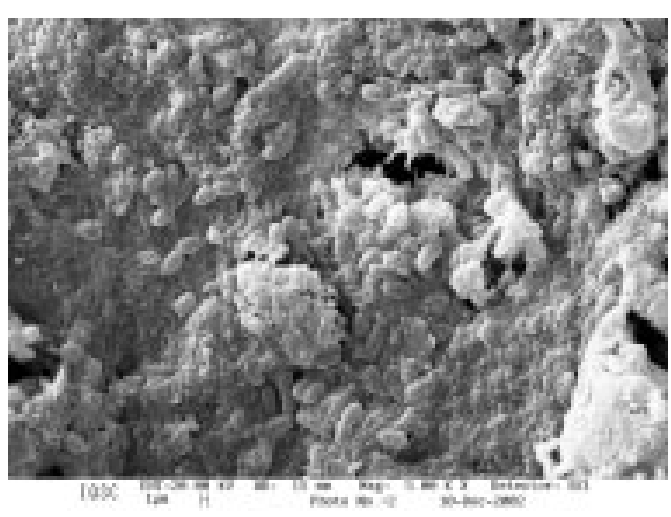

(a)

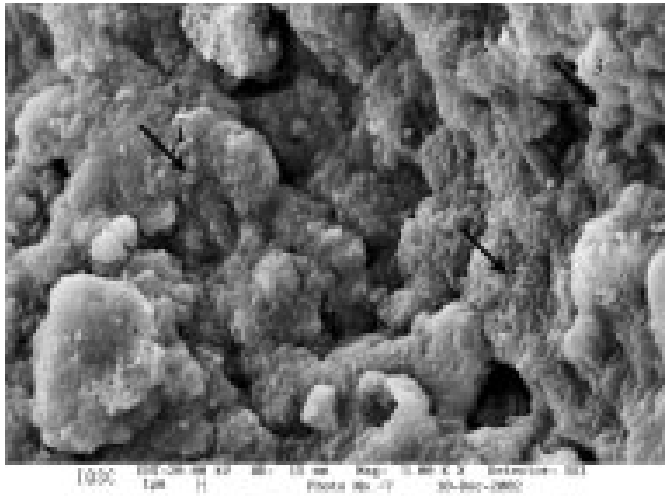

(b)

FIGURA 5.20 - Morfologias presentes no material suporte aos 62 dias de operação (149 ciclos), através de microscopia eletrônica de varredura, com aumento de 5.000x, semelhantes a: (a) cocos e bacilos de diversas dimensões; (b1) cocos; (b2) bacilos agrupados; (b3) microrganismo semelhante a Methanosarcina sp.

\subsubsection{Morfologias presentes no lodo na superfície do cesto de imobilização}

Uma fina camada de lodo formou-se acima da tampa do cesto, que coincidia com o nível máximo de esgoto sanitário no ASBR. Por apresentar coloração mais clara que o material suporte com biofilme aderido, decidiu-se fazer exame microscópico para identificar as morfologias presentes nesse material.

Foram encontradas bacilos de diversas dimensões, alguns cocos e víbrios, microrganismos semelhantes a Beggiatoa sp., Paramecium sp., Sphaerotilus sp., nematóide, e rotífero, que podem ser visualizados na FIGURA 5.21. As morfologias registradas foram identificadas através de comparação com morfologias apresentadas por JENKINS et al. (1993) e VAZOLLER et al. (1992). RIBEIRO (2001) também observou a presença de protozoários no ciclo utilizando esgoto sintético, atribuindo a maior complexidade do meio.

No final da operação, não foi mais detectado a presença desse lodo superficial. Fato atribuído à melhor vedação do reator. 


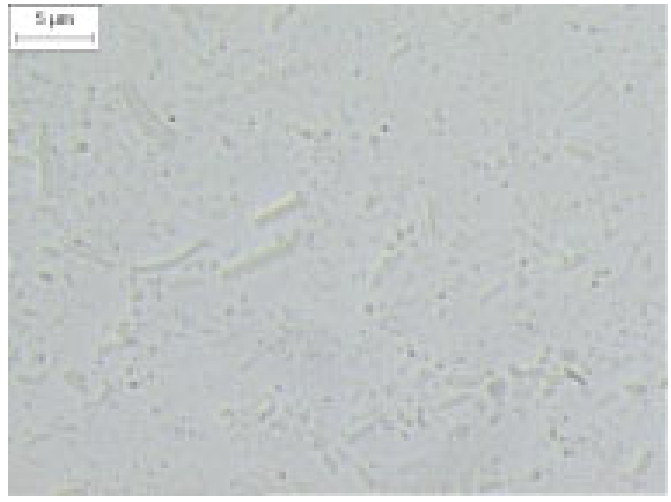

(a)

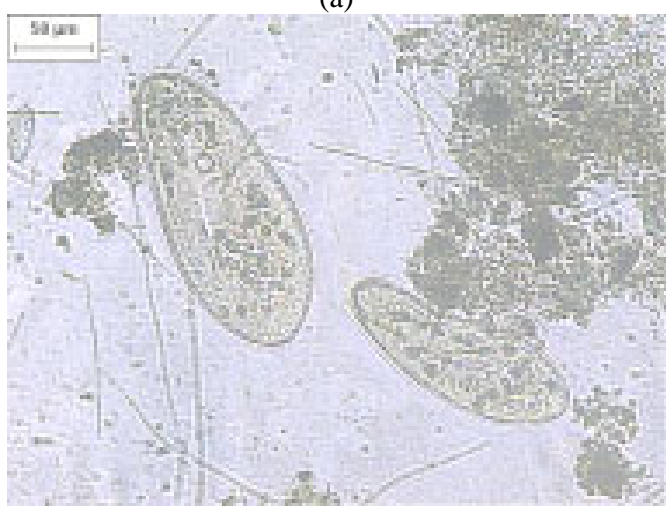

(c)

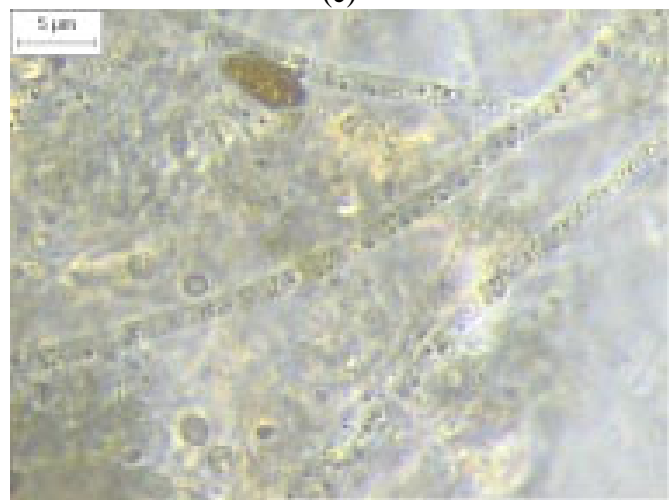

(e)

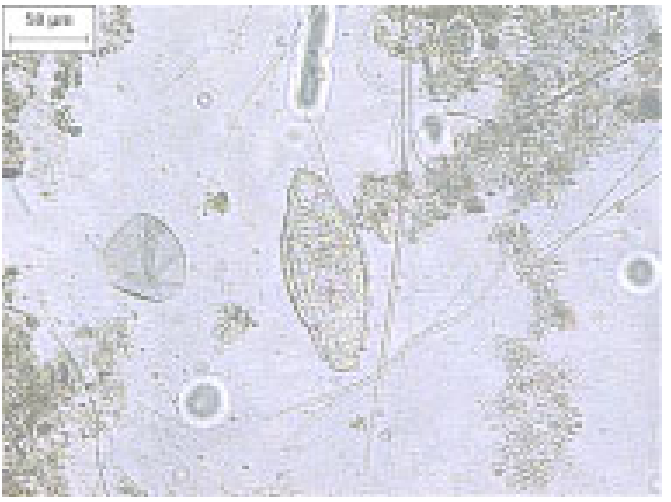

(b)

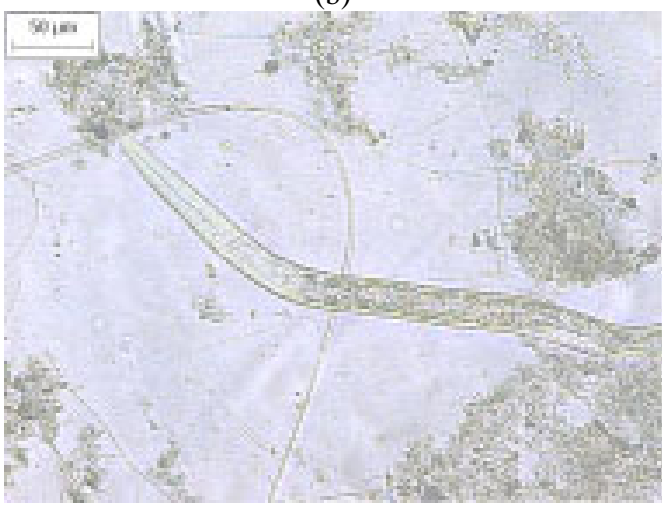

(d)

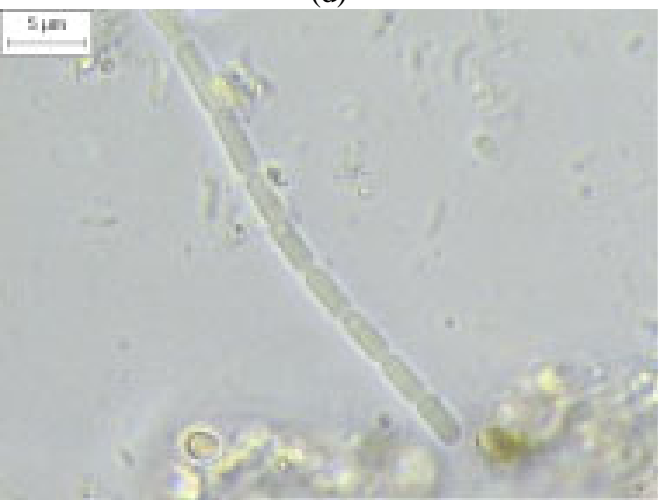

(f)

FIGURA 5.21 - Morfologias presentes no lodo superficial formado acima do cesto de imobilização, através de microscopia ótica, semelhantes a: (a) cocos e bacilos de diversas dimensões, aumento de 1.500x; (b) rotífero, aumento de 150x; (c) Paramecium sp., aumento de 150x; (d) nematóide, aumento de 150x; (e) microrganismo semelhante a Beggiatoa sp., aumento de 1.500x; (f) microrganismo semelhante a Sphaerotilus sp., aumento de $1.500 \mathrm{x}$.

\subsubsection{Morfologias presentes no material suporte no final da operação}

No final da operação do sistema foram retiradas amostras da superfície, do meio e do fundo do reator, assim como amostra do lodo remanescente de cada batelada no fundo do reator. As amostras foram examinadas por microscopia ótica e eletrônica de varredura, conforme descrito no item 4.2.3. 
As morfologias presentes no material suporte na superfície do reator aparentemente indicam grande variedade de células microbianas, com predominância de bacilos com extremidades arredondadas, bactérias fotoanoxigênicas semelhantes a Chromatium sp., víbrios, microrganismos semelhantes a Methanosarcina sp., presença de bacilos semelhantes a BRS, bacilos alongados com inclusões e bacilos em cadeia. As imagens obtidas com microscopia ótica podem ser vistas na FIGURA 5.22. 


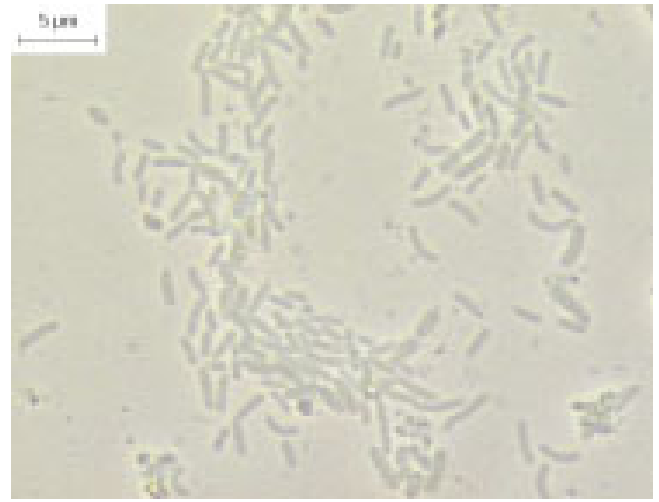

(a)

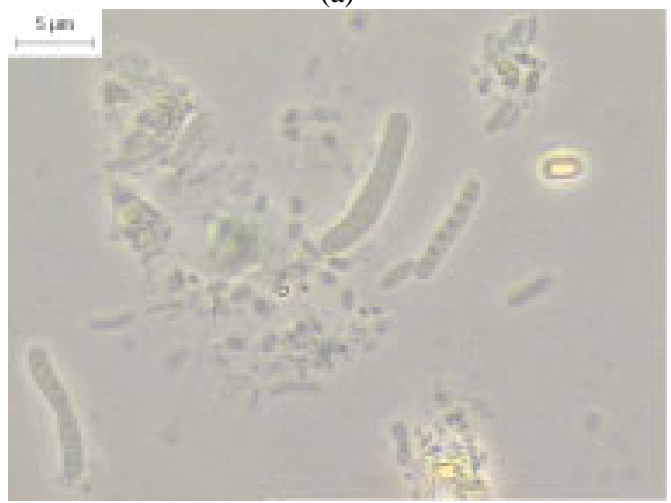

(c)

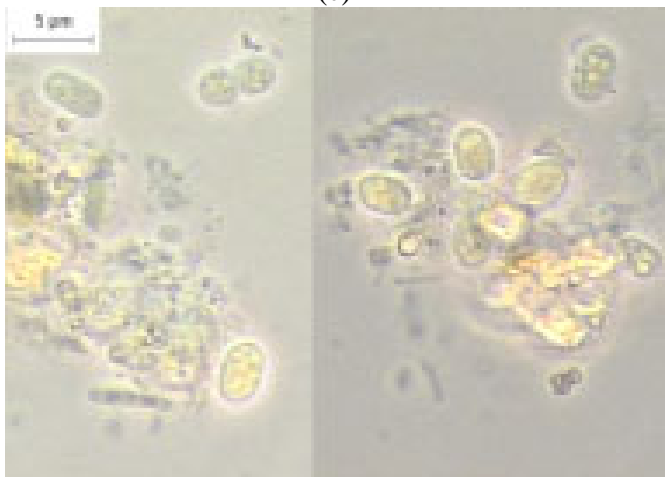

(e)

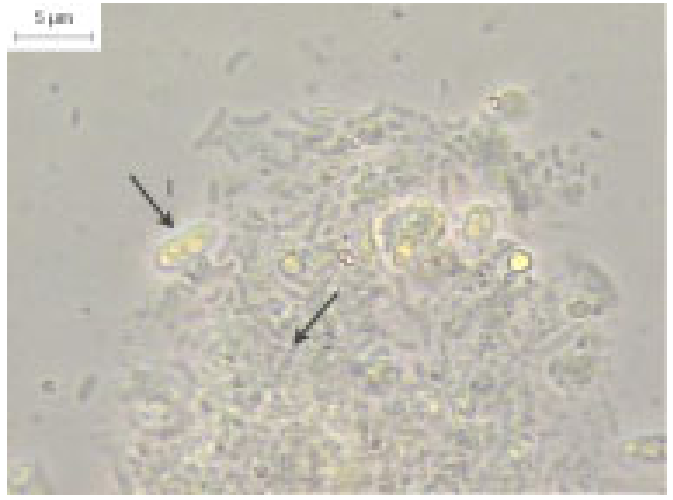

(b)

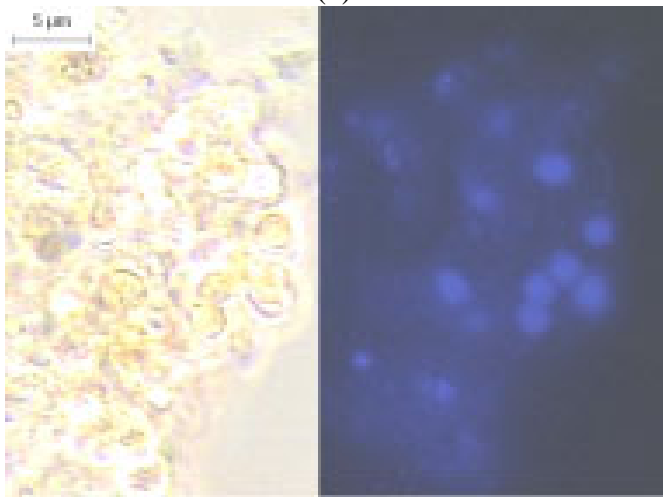

(d)

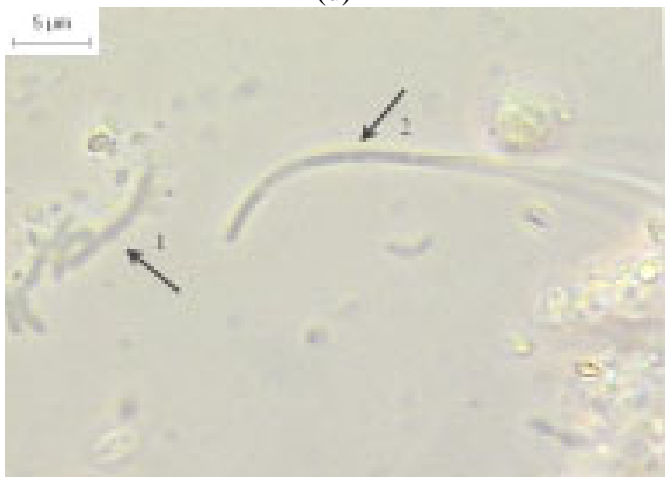

(f)

FIGURA 5.22 - Morfologias presentes no material suporte na superfície do reator, através de microscopia ótica, com aumento de 1.500x, semelhantes a: (a) bacilos de diversas dimensões; (b1) bactéria fotoanoxigênica; (b2) bacilos semelhantes a BRS; (c) bacilos alongados com inclusões; (d) morfologias semelhantes a cocos fluorescentes; (e) microrganismos semelhantes a Chromatium sp.; (f1) bacilos em cadeia; (f2) microrganismo semelhante a Methanosaeta sp.

No centro do reator foi observada predominância de bacilos semelhantes a bactérias redutoras de sulfato (BRS), bactérias fotoanoxigênicas, semelhantes a Chromatium sp., microrganismos semelhantes a Methanosaeta sp.; pouca freqüência de bacilos fluorescentes, bacilos retos, alongados, com extremidades arredondadas, coco-bacilos e microrganismos 
semelhantes a Methanosarcina sp; raros víbrios e bacilos alongados com inclusões. As imagens obtidas com microscopia ótica podem ser vistas na FIGURA 5.23.

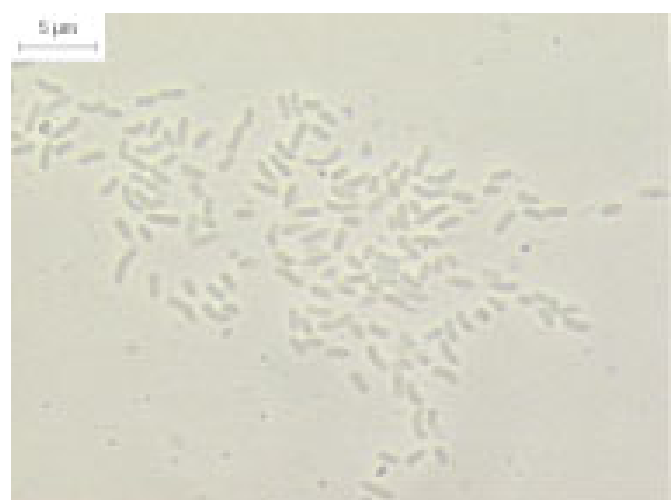

(a)

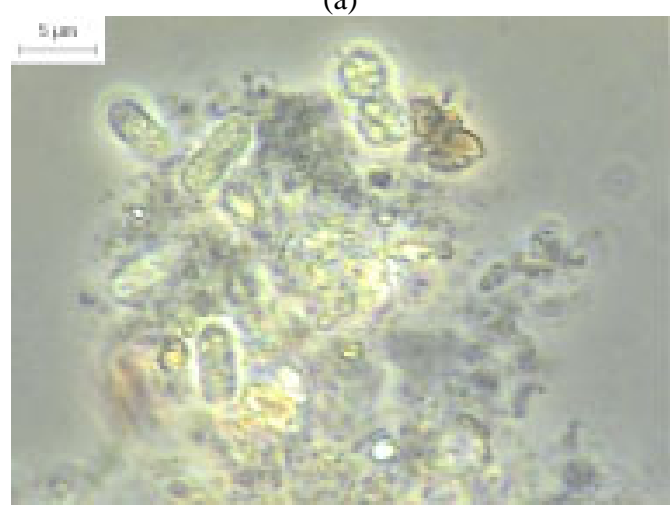

(c)

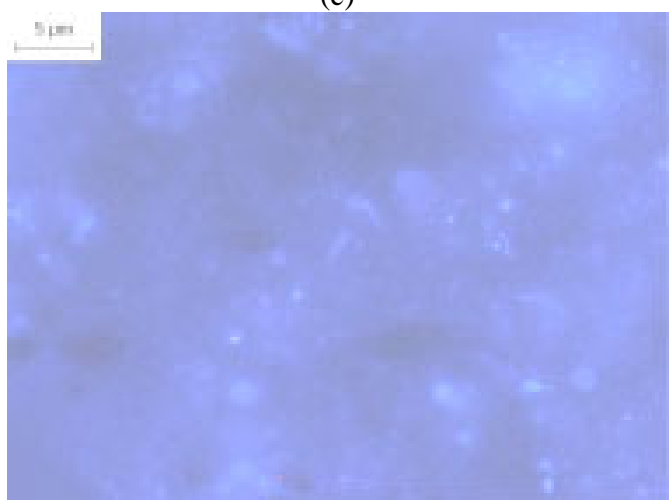

(e)

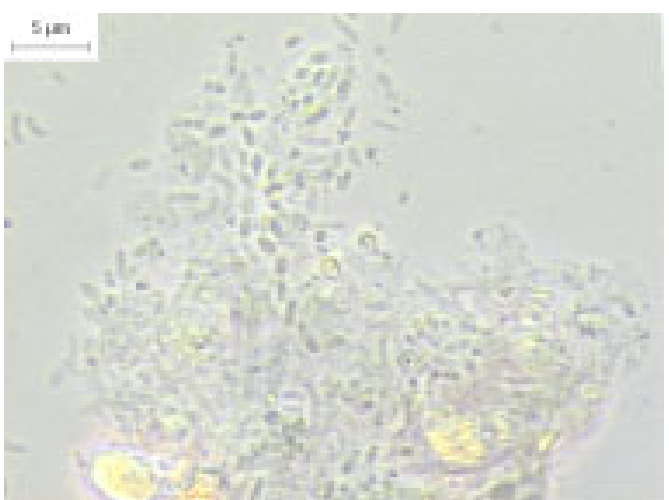

(b)

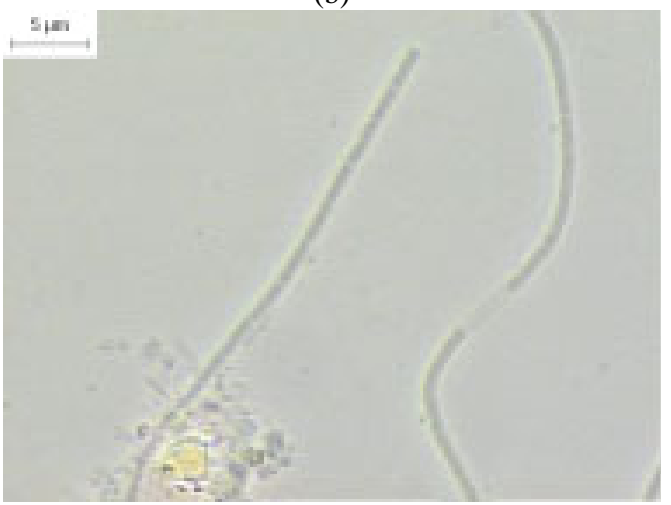

(d)

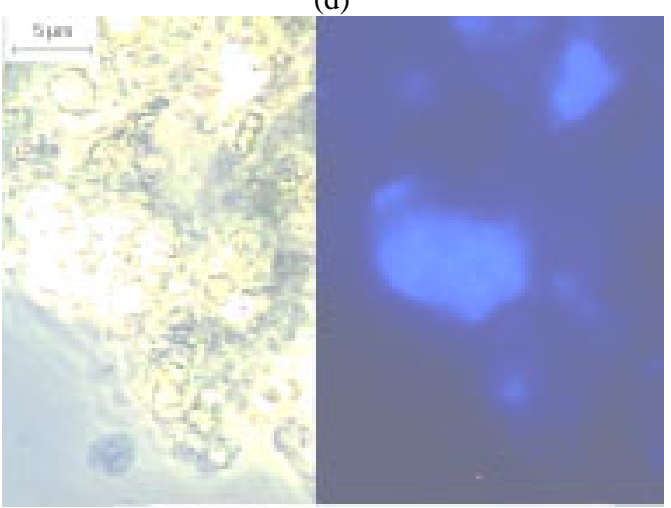

(f)

FIGURA 5.23 - Morfologias presentes no material suporte no centro do reator, através de microscopia ótica, com aumento de 1.500x, semelhantes a: (a) e (b) bacilos semelhantes a BRS; (c) células fotoanoxigênicas, semelhantes a Chromatium sp.; (d) microrganismos semelhantes a Methanosaeta sp.; (e) bacilos fluorescentes; (f) microrganismos semelhantes a Methanosarcina sp.

O biofilme aderido ao material suporte, presente no fundo do reator, apresentou predominância de bacilos semelhantes a BRS; freqüentes bacilos de diversas dimensões; 
pouca ocorrência de bacilos fluorescentes e víbrios e raros bacilos alongados com inclusões, bactérias fotoanoxigênicas, semelhantes a Chromatium sp. e microrganismos semelhantes a Methanosaeta sp. As imagens obtidas com microscopia ótica podem ser vistas na FIGURA 5.24 .

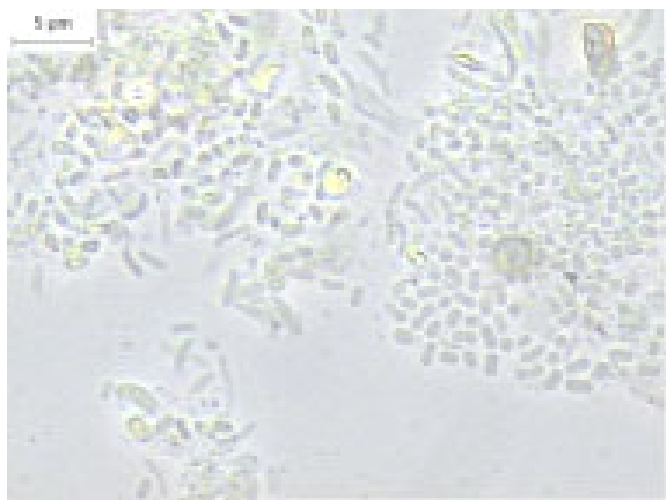

(a)

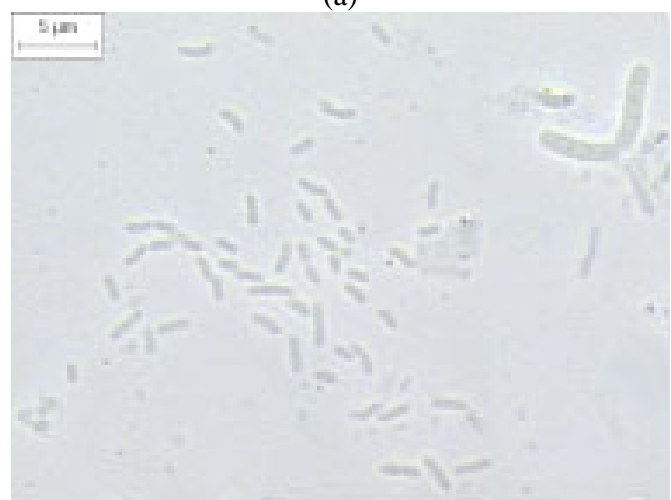

(c)

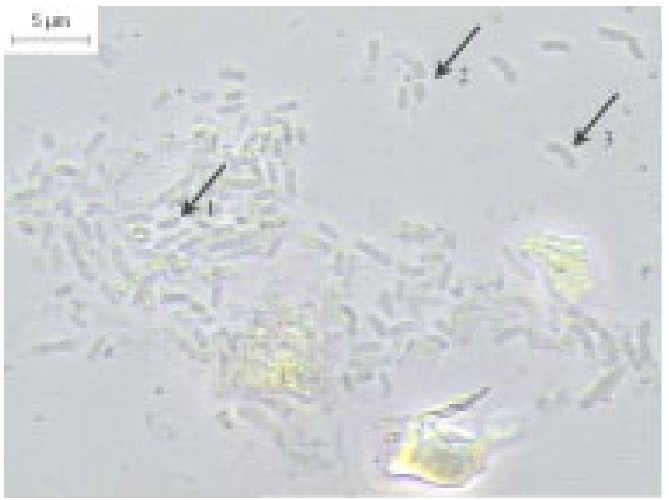

(b)

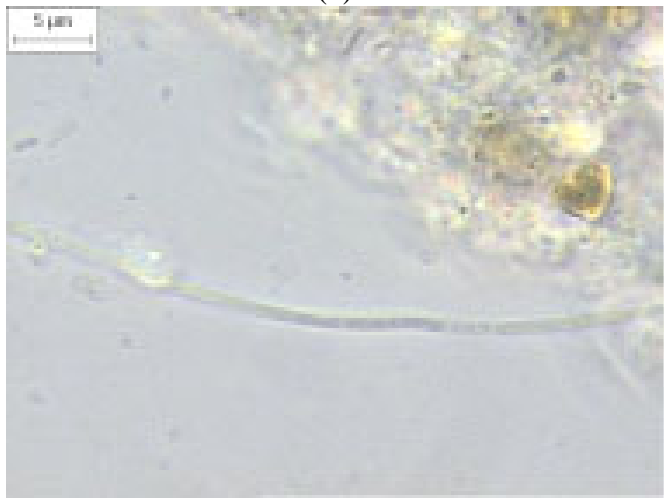

(d)

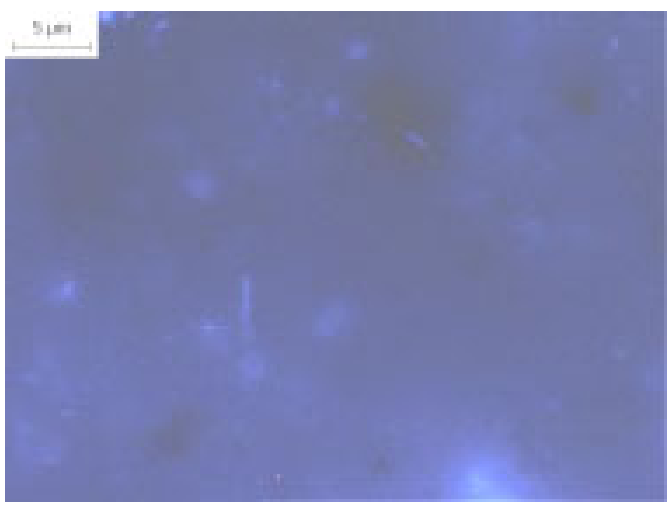

(e)

FIGURA 5.24 - Morfologias presentes no material suporte no fundo do reator, através de microscopia ótica, com aumento de 1.500x, semelhantes a: (a) e (b1) bacilos semelhantes a BRS; (b2) cocos; (b3) víbrio; (c) bacilos de diversas morfologias; (d) microrganismo semelhante a Methanosaeta sp.; (e) bacilos fluorescentes metanogênicos. 
As amostras de pedra pome com biofilme aderido foram examinadas com microscopia eletrônica de varredura. As morfologias observadas estão na FIGURA 5.25, com microrganismos semelhantes a bacilos arredondados, cocos, bacilos em cadeia, bacilos arredondados, semelhantes a Chromatium sp., microrganismos semelhantes a Methanosarcina sp. e Methanosaeta sp., confirmando as morfologias observadas na microscopia ótica.

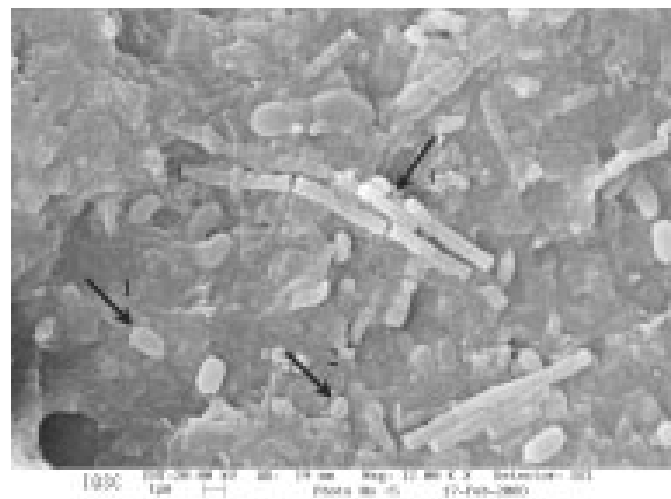

(a)

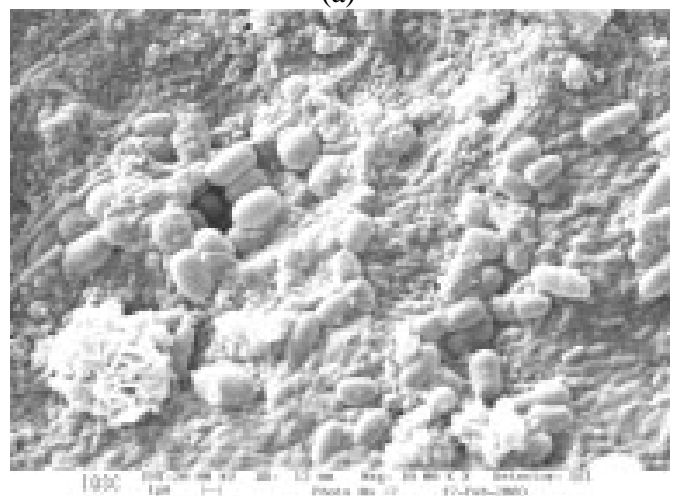

(c)

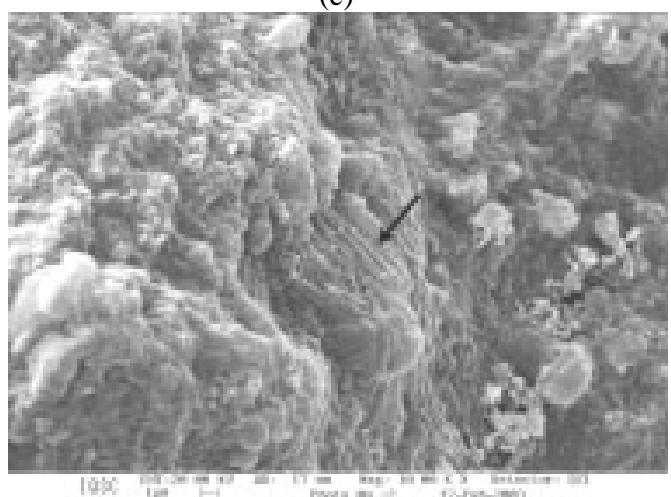

(e)

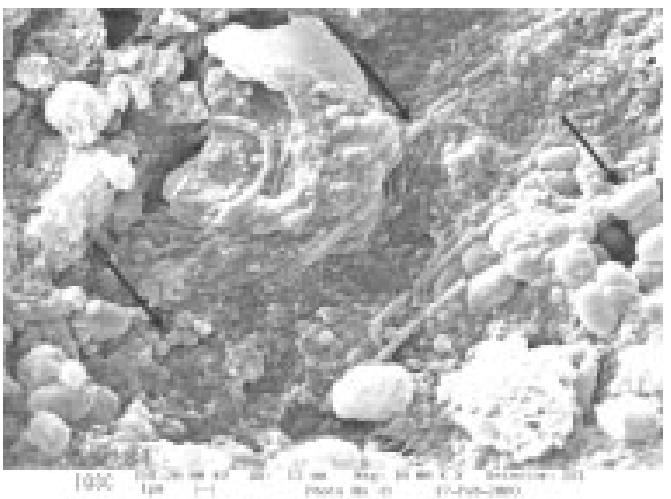

(b)

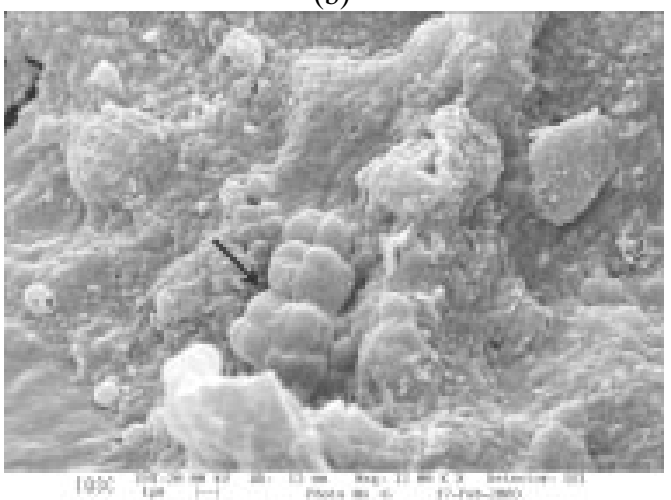

(d)

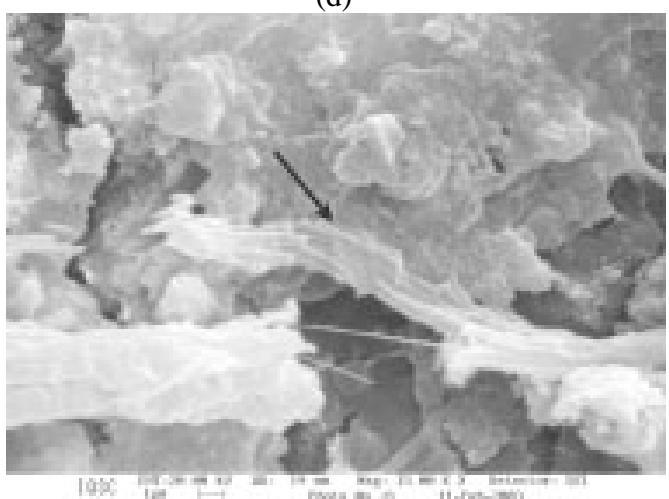

(f)

FIGURA 5.25 - Morfologias presentes no material suporte no final da operação, através de microscopia eletrônica de varredura, semelhantes a: (a1) e (b3) bacilos arredondados; (a2) e (b1) cocos (a3) bacilos longos em cadeia; (b2) bacilos em cadeia; (c) bacilos arredondados, semelhantes a Chromatium sp.; (d) microrganismo semelhante a Methanosarcina sp.; (e) e (f) microrganismo semelhante a Methanosaeta sp. 
As morfologias presentes no lodo remanescente no fundo do reator apresentaram predominância de microrganismos semelhantes a Methanosaeta sp., bacilos delgados; frequiência de microrganismo semelhante a Methanosarcina sp. e bacilos fluorescentes; pouca frequiência de bacilos alongados com inclusões. As imagens obtidas com microscopia ótica podem ser vistas na FIGURA 5.26.

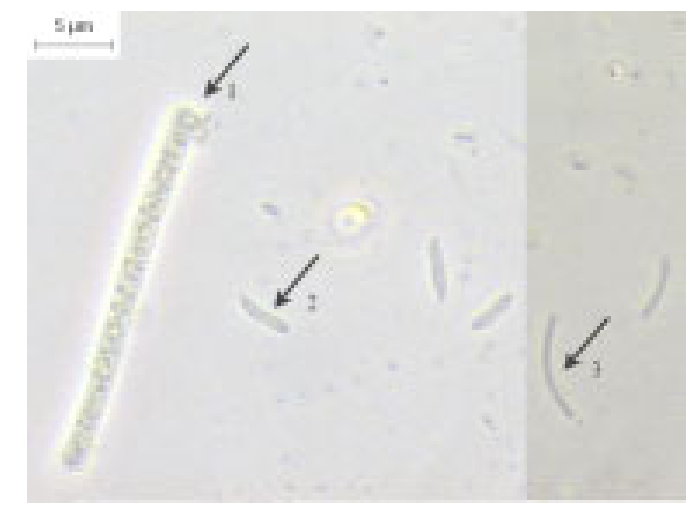

(a)

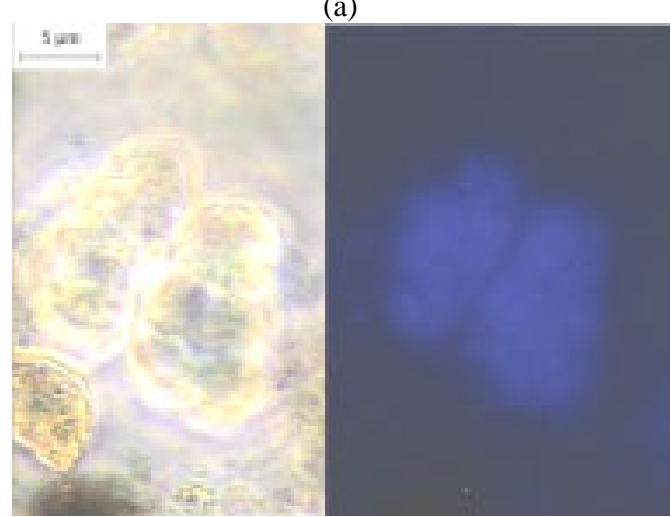

(c)

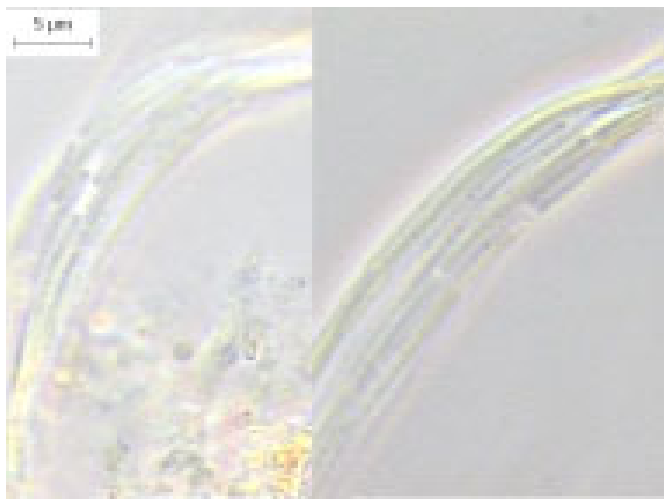

(b)

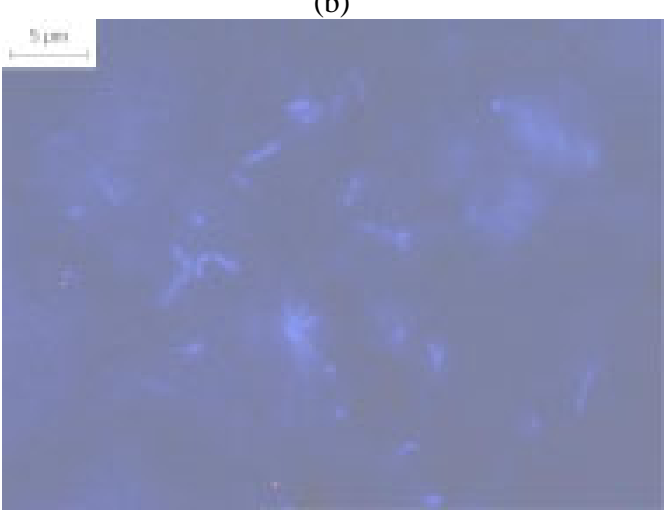

(d)

FIGURA 5.26 - Morfologias presentes no lodo remanescente no fundo do reator, através de microscopia ótica, com aumento de 1.500x, semelhantes a: (a1) bacilo alongado com inclusões; (a2) bacilos afilados; (a3) bacilos delgados; (b) microrganismo semelhante a Methanosaeta sp. (c) microrganismo semelhante a Methanosarcina sp.; (d) bacilos fluorescentes metanogênicos.

Foi elaborada uma tabela qualitativa a fim de resumir todas as morfologias observadas por microscopia ótica de luz comum e contraste de fases e microscopia eletrônica de varredura, do inóculo, da pedra pome aos 62 dias de operação e no final da operação, com 84 dias, que pode ser visualizada na TABELA 5.4.

As morfologias observadas por VERONEZ et al. (2002), em grânulos de reator ASBR, são semelhantes às encontradas nesta pesquisa. Essa foi a única literatura encontrada 
que pôde ser parcialmente comparada à esta investigação. Nos materiais suportes estudados por SILVA et al. (2002) também foram observadas predominância de microrganismos do domínio bactéria, através de contagem por meio de técnicas de biologia molecular.

A presença de células fotoanoxigênicas no reator pode ter sido favorecida pela presença de luz, ocorrida no trecho de mangueira de silicone transparente, na entrada do reator. No início da operação, o reator ficava coberto por pano preto e depois foi decidido cobri-lo com papel alumínio para protegê-lo ainda mais da luz natural. As células encontradas assemelharam-se a microrganismos do gênero Chromatium. Esses microrganismos removem sulfeto e produzem enxofre em condições anóxicas e sem iluminação, a partir de ácido sulfídrico $\left(\mathrm{H}_{2} \mathrm{~S}\right)$, presentes na água residuária (PFENNIG, 1978).

Segundo VARESCHE (1997), além da capacidade de remover compostos reduzidos de enxofre, os microrganismos fototróficos anoxigênicos são também capazes de assimilar para o seu desenvolvimento matéria orgânica presente em muitas águas residuárias, podendo representar papel importante na purificação desses sistemas.

Muitas bactérias redutoras do íon sulfato (BRS) são encontradas em associação com as arqueas metanogênicas nos ambientes anaeróbios (NOVAES, 1986). Na ausência de sulfato, as bactérias redutoras comportam-se como microrganismos acetogênicos, utilizando lactato e etanol para produzir substratos, como acetato, gás carbônico e hidrogênio para as metanogências (FIGUEIREDO \& VAZOLLER, 1991).

Houve grande dificuldade nas análises microbiológicas devido a presença de material inerte nas lâminas. Para obter melhor qualidade de visualização dos microrganismos foi, utilizado detergente Tween 80 , juntamente com equipamento de ultra-som, da marca Thornton T-7 por 10 minutos.

Ao longo da superfície externa das partículas de pedra pome foi observado distribuição heterogênea dos microrganismos, regiões com aglomerados de microrganismos e regiões sem morfologia aparente. Além disso, a colonização dos microrganismos ocorreu 
próxima aos poros, cavidades e elementos inorgânicos presentes na superfície externa. Essa evidência também foi constatada por PEREIRA et al. (1997) que trabalharam com carvão ativado como material suporte.

TABELA 5.4 - Morfologias dos microrganismos presentes no inóculo e pedra pome imobilizada aos dois meses e no final da operação.

\begin{tabular}{|c|c|c|c|c|c|}
\hline \multirow{3}{*}{ Morfologias encontradas } & \multirow{3}{*}{ Inóculo } & \multicolumn{4}{|c|}{ Pedra pome } \\
\hline & & \multirow{2}{*}{62 dias } & \multicolumn{3}{|c|}{ Final operação (84 dias) } \\
\hline & & & Superfície & Centro & Fundo \\
\hline Bacilos alongados & ++++ & +++ & - & ++ & - \\
\hline Bacilos alongados com inclusões & - & ++++ & ++ & + & + \\
\hline Bacilos com extremidades afiladas & - & + & + & - & - \\
\hline Bacilos com extremidades arredondadas & ++++ & ++ & ++++ & ++ & +++ \\
\hline Bacilos em cadeia & - & - & + & - & - \\
\hline Bacilos fluorescentes & ++ & + & - & ++ & ++ \\
\hline Bacilos retos & +++ & +++ & + & ++ & - \\
\hline Bacilos semelhantes a BRS & - & - & ++ & ++++ & ++++ \\
\hline Bactécias fotoanoxigênicas & - & +++ & +++ & +++ & + \\
\hline Coco-bacilos & - & + & - & ++ & - \\
\hline $\operatorname{Cocos}$ & +++ & - & ++ & - & - \\
\hline Cocos em tétrades & ++ & - & - & - & - \\
\hline Cocos fluorescentes & ++ & - & + & - & - \\
\hline Espiroquetas & - & + & - & - & - \\
\hline Filamentos & + & - & + & - & - \\
\hline Filamentos com inclusões & - & ++ & - & - & - \\
\hline Methanosaeta sp. & +++ & - & ++ & +++ & + \\
\hline Methanosarcina sp. & ++++ & +++ & +++ & ++ & - \\
\hline Víbrios & + & +++ & +++ & + & ++ \\
\hline
\end{tabular}

$(++++)$ Predominantes, $(+++)$ freqüentes, $(++)$ pouco freqüentes, $(+)$ raros, $(-)$ não foram encontrados. 


\section{CONCLUSÕES}

Os resultados de operação de um reator anaeróbio em batelada seqüencial de leito fixo formado por matrizes de pedra pome, provido de agitador mecânico, obtidos no tratamento de esgoto sanitário durante 86 dias de operação, totalizando 216 ciclos de oito horas, permitiram concluir que:

- O reator demonstrou ser de fácil operação e controle e apresentou bom desempenho na remoção de DQO. Para a DQO média afluente de $446 \pm 169 \mathrm{mg} / \mathrm{L}$, os valores médios obtidos no efluente foram de $233 \pm 52 \mathrm{mg} / \mathrm{L}$ para DQO total, obtida de amostras totais, $64 \pm 31 \mathrm{mg} / \mathrm{L}$ para DQO particulada, $32 \pm 15 \mathrm{mg} / \mathrm{L}$ para DQO coloidal e $141 \pm 32 \mathrm{mg} / \mathrm{L}$ para DQO solúvel. A maior eficiência de remoção foi obtida para a matéria orgânica particulada.

- No ensaio realizado para se determinar o perfil temporal das características do líquido no interior do reator, ao longo de uma batelada, observou-se que, decorridas quatro horas do início do ciclo, o reator já havia atingido a eficiência máxima de remoção de DQO. Portanto, a duração da batelada pode ser reduzida, sem prejuízo para o desempenho do reator.

- Houve redução elevada de sólidos em suspensão totais (SST), com eficiência média de remoção de $70 \%$ e o reator manteve relativamente constante a capacidade de remoção de SST durante toda a operação. Os valores médios de sólidos suspensos voláteis (SSV) no afluente e no efluente foram de $120 \pm 64 \mathrm{mg} / \mathrm{L}$ e $36 \pm 16 \mathrm{mg} / \mathrm{L}$, respectivamente. Os resultados apresentados demonstram que a maior parte dos sólidos suspensos totais (SST) era constituída de SSV. 
- O valor do pH manteve-se relativamente constante, com valores médios afluente de 6,7 \pm 0,5 e efluente de $8,0 \pm 0,5$. A elevação de uma unidade no valor do $\mathrm{pH}$ foi atribuída à presença de hidroxila $\left(\mathrm{OH}^{-}\right)$resultante das reações do cálcio no meio líquido, que por ser um dos constituintes da pedra pome, foi solubilizado para o meio, devido ao ataque pelos ácidos orgânicos produzidos nos processos anaeróbios. O estudo de perfil temporal de pH, ao longo de um ciclo, permitiu constatar que não houve alterações significativas no seu valor durante o tempo de reação.

- Os valores elevados de dureza encontrados no efluente confirmam que houve solubilização de cálcio, constituinte importante da pedra pome sintética.

- O reator apresentou no efluente valor médio de alcalinidade a bicarbonato, muito superior aos esperados em unidades anaeróbias de tratamento de esgotos sanitários. A média de alcalinidade a bicarbonato afluente foi de $131 \pm 32 \mathrm{mg} / \mathrm{L}$ e a efluente de $240 \pm$ $44 \mathrm{mg} / \mathrm{L}$, o que corresponde a aumento médio de $82 \%$. Concluiu-se que parte significativa da alcalinidade gerada era decorrente da solubilização do cálcio presente na pedra pome e de sua interação com as espécies químicas do sistema carbonato.

- As análises de ácidos voláteis totais (AVT) indicaram que houve pequena variação entre os valores médios do afluente e do efluente. As concentrações no efluente foram ligeiramente superiores às do afluente, com médias de $54 \pm 13 \mathrm{mg} / \mathrm{L}$ para AVT afluente e $69 \pm 15 \mathrm{mg} / \mathrm{L}$ para AVT efluente, o que corresponde ao aumento médio de $26 \%$. Concentrações relativamente elevadas de AVT também têm sido observadas, nos efluentes de outros reatores anaeróbios utilizados no tratamento de esgotos sanitários e esse fato merece atenção especial em estudos futuros.

- Os valores de potencial de oxi-redução (POR), medidos durante o ensaio de levantamento do perfil temporal, mostraram que ao longo do ciclo prevaleceram condições anaeróbias. O POR de entrada era de $-113 \mathrm{mV}$, passando a aproximadamente 
-300 mV nos primeiros 11 minutos, para $-350 \mathrm{mV}$ após 1 hora e mantendo-se em -400 $\mathrm{mV}$ nas últimas 3 horas.

- O perfil de alcalinidade a bicarbonato $(\mathrm{AB})$ apresentou valores de $103 \mathrm{mg} / \mathrm{L}$ no afluente e atingiu $289 \mathrm{mg} / \mathrm{L}$ (181\% superior à $\mathrm{AB}$ de entrada), após aproximadamente quatro horas de reação, mantendo-se praticamente constante nas quatro horas restantes do ciclo. Esse resultado confirma que a perda elevada de cálcio da pedra pome foi devida às reações dos constituintes da pedra pome com os ácidos orgânicos gerados nos processos anaeróbios.

- Os dados do perfil de DQO permitiram o ajuste de modelo cinético de reação de primeira ordem, com residual, sendo obtidos os valores de $\mathrm{k}_{1}{ }^{\text {ap }}$ de $1,42 \pm 0,13 \mathrm{~h}^{-1}$ para a remoção da DQO total, 1,53 $\pm 0,09 \mathrm{~h}^{-1}$ para a remoção da fração particulada e $4,81 \pm 0,94 \mathrm{~h}^{-1}$ para a remoção da fração solúvel. O melhor ajuste foi obtido para os dados de DQO particulada, com coeficiente de correlação igual a 0,98 .

- A biomassa presente no material suporte, no final da operação, apresentou grande variedade de células microbianas, com predominância bacilos de diversas morfologias, bactérias fotoanoxigênicas semelhantes a Chromatium sp., víbrios, microrganismos semelhantes a Methanosarcina sp. e Methanosaeta sp., presença de bacilos morfologicamente semelhantes às BRS, bacilos alongados com inclusões e bacilos em cadeia.

- Houve grande dificuldade nas análises microbiológicas devido à presença de material inerte nas lâminas. Após preparadas as amostras com adição do detergente Tween 80, e submetidas a ultra-som por 10 minutos, foi possível preparar lâminas que permitiram melhor visualização das morfologias microbianas.

- A pedra pome sintética não apresentou a estabilidade química necessária para seu uso como material suporte da biomassa em reatores anaeróbios, pois ocorreu a perda contínua de cálcio do leito, que resultou na perda da estabilidade estrutural das matrizes. 


\section{SUGESTÕES}

De acordo com os resultados obtidos durante a operação do ASBR com biomassa imobilizada, são feitas as seguintes sugestões para pesquisas vindouras:

- Avaliar o desempenho do reator anaeróbio em batelada seqüencial utilizando outros materiais suportes como carvão vegetal, carvão ativado, cerâmica porosa, etc;

- Realizar pesquisa no mesmo reator com pedra pome natural para avaliar seu desempenho como material suporte para crescimento dos microrganismos;

- Estudar a influência da intensidade de agitação na colonização de matrizes suportes inertes;

- Estudar o efeito da variação do tempo de enchimento do reator, para caracterizar as diferenças entre operação em batelada e em batelada alimentada, no tratamento de esgoto sanitário;

- Acompanhar o desempenho do reator anaeróbio em batelada seqüencial com biomassa imobilizada, tratando esgoto sanitário, reduzindo-se o tempo de reação para 4 horas. 


\section{ANEXOS}


ANEXO A - Tabela de monitoramento da demanda química de oxigênio (DQO), total e filtrada.

\begin{tabular}{|c|c|c|c|c|c|c|c|c|c|}
\hline \multirow{3}{*}{$\begin{array}{c}\text { Ciclo } \\
\text { analisado }\end{array}$} & \multicolumn{9}{|c|}{ Demanda química de oxigênio (mg/L) } \\
\hline & \multicolumn{3}{|c|}{ Total } & \multicolumn{3}{|c|}{ Filtrada $_{1,2}$} & \multicolumn{3}{|c|}{ Filtrada $_{0,45}$} \\
\hline & Afluente & Efluente & Ef. $^{*}$ & Afluente & Efluente & Ef. $^{*}$ & Afluente & Efluente & Ef. $^{*}$ \\
\hline $5^{0}$ & 245 & 275 & & 179 & 197 & $20 \%$ & 144 & 144 & $41 \%$ \\
\hline $8^{\circ}$ & 263 & 183 & $30 \%$ & 203 & 137 & $48 \%$ & 169 & 85 & $68 \%$ \\
\hline $12^{\circ}$ & 221 & 180 & $19 \%$ & 136 & 129 & $41 \%$ & 109 & 119 & $46 \%$ \\
\hline $20^{\circ}$ & 445 & 252 & $43 \%$ & 243 & 178 & $60 \%$ & 228 & 142 & $68 \%$ \\
\hline $24^{\circ}$ & 573 & 241 & $58 \%$ & 203 & 183 & $68 \%$ & 167 & 131 & $77 \%$ \\
\hline $30^{\circ}$ & 458 & 319 & $30 \%$ & 173 & 155 & $66 \%$ & 134 & 103 & $77 \%$ \\
\hline $36^{\circ}$ & 503 & 282 & $44 \%$ & 242 & 199 & $61 \%$ & 229 & 171 & $66 \%$ \\
\hline $45^{\circ}$ & 696 & 287 & $59 \%$ & 197 & 205 & $71 \%$ & 124 & 167 & $76 \%$ \\
\hline $51^{\circ}$ & 475 & 312 & $34 \%$ & 257 & 245 & $48 \%$ & 208 & 186 & $61 \%$ \\
\hline $56^{\circ}$ & 762 & 306 & $60 \%$ & 228 & 233 & $69 \%$ & 201 & 195 & $74 \%$ \\
\hline $57^{\circ}$ & 580 & 267 & $54 \%$ & 249 & 197 & $66 \%$ & 206 & 167 & $71 \%$ \\
\hline $78^{\circ}$ & 789 & 287 & $64 \%$ & 210 & 201 & $75 \%$ & 184 & 172 & $78 \%$ \\
\hline $87^{\circ}$ & 365 & 216 & $41 \%$ & 161 & 167 & $54 \%$ & 125 & 135 & $63 \%$ \\
\hline $93^{\circ}$ & 350 & 234 & $33 \%$ & 215 & 179 & $49 \%$ & $\star *$ & $\star *$ & $* *$ \\
\hline $99^{\circ}$ & 457 & 208 & $55 \%$ & 236 & 210 & $54 \%$ & $\star \star$ & $* *$ & $* *$ \\
\hline $108^{\circ}$ & 283 & 218 & $23 \%$ & 141 & 162 & $43 \%$ & 106 & 142 & $50 \%$ \\
\hline $116^{\circ}$ & 649 & 267 & $59 \%$ & 196 & 182 & $72 \%$ & 161 & 165 & $75 \%$ \\
\hline $128^{\circ}$ & 400 & 194 & $52 \%$ & 152 & 145 & $64 \%$ & $\star \star$ & $\star \star$ & $\star *$ \\
\hline $135^{\circ}$ & 354 & 192 & $46 \%$ & 158 & 161 & $55 \%$ & 140 & 145 & $59 \%$ \\
\hline $141^{\circ}$ & 365 & 238 & $35 \%$ & 178 & 206 & $44 \%$ & $* *$ & $\star *$ & $* *$ \\
\hline $149^{\circ}$ & 376 & 220 & $42 \%$ & 177 & 188 & $50 \%$ & ** & $* *$ & $\star *$ \\
\hline $159^{\circ}$ & 648 & 215 & $67 \%$ & 172 & 169 & $74 \%$ & 157 & 153 & $76 \%$ \\
\hline $174^{\circ}$ & 426 & 162 & $62 \%$ & 129 & 128 & $70 \%$ & 100 & 100 & $77 \%$ \\
\hline $180^{\circ}$ & 217 & 138 & $37 \%$ & 110 & 116 & $47 \%$ & 90 & 107 & $51 \%$ \\
\hline $195^{\circ}$ & 244 & 139 & $43 \%$ & 147 & 115 & $53 \%$ & 131 & 95 & $61 \%$ \\
\hline Média & 446 & 233 & $48 \%$ & 188 & 175 & $61 \%$ & 155 & 141 & $68 \%$ \\
\hline $\begin{array}{l}\text { Desvio } \\
\text { Padrão }\end{array}$ & 169 & 52 & & 41 & 34 & & 43 & 32 & \\
\hline Máximo & 789 & 319 & $67 \%$ & 257 & 245 & $75 \%$ & 229 & 195 & $78 \%$ \\
\hline Mínimo & 217 & 138 & $19 \%$ & 110 & 115 & $20 \%$ & 90 & 85 & $41 \%$ \\
\hline
\end{tabular}


ANEXO B - Tabela de DQO fracionada em DQO particulada, coloidal e solúvel.

\begin{tabular}{|c|c|c|c|c|c|c|c|c|c|}
\hline \multirow{3}{*}{$\begin{array}{c}\text { Ciclo } \\
\text { analisado }\end{array}$} & \multicolumn{9}{|c|}{ Demanda química de oxigênio (mg/L) } \\
\hline & \multicolumn{3}{|c|}{ Particulada } & \multicolumn{3}{|c|}{ Coloidal } & \multicolumn{3}{|c|}{ Solúvel } \\
\hline & Afluente & Efluente & Ef. & Afluente & Efluente & Ef. & Afluente & Efluente & Ef. \\
\hline $5^{0}$ & 66 & 78 & & 35 & 53 & & 144 & 144 & \\
\hline $8^{\circ}$ & 60 & 47 & $22 \%$ & 34 & 52 & $0 \%$ & 169 & 85 & $50 \%$ \\
\hline $12^{0}$ & 85 & 51 & $40 \%$ & 28 & 10 & $64 \%$ & 109 & 119 & $0 \%$ \\
\hline $20^{\circ}$ & 202 & 74 & $64 \%$ & 16 & 37 & $0 \%$ & 228 & 142 & $38 \%$ \\
\hline $24^{\circ}$ & 370 & 58 & $84 \%$ & 36 & 52 & $0 \%$ & 167 & 131 & $22 \%$ \\
\hline $30^{\circ}$ & 285 & 164 & $42 \%$ & 40 & 52 & $0 \%$ & 134 & 103 & $23 \%$ \\
\hline $36^{\circ}$ & 262 & 84 & $68 \%$ & 13 & 28 & $0 \%$ & 229 & 171 & $25 \%$ \\
\hline $45^{\circ}$ & 499 & 82 & $84 \%$ & 73 & 38 & $48 \%$ & 124 & 167 & $0 \%$ \\
\hline $51^{\circ}$ & 218 & 68 & $69 \%$ & 50 & 59 & $0 \%$ & 208 & 186 & $10 \%$ \\
\hline $56^{\circ}$ & 534 & 74 & $86 \%$ & 27 & 38 & $0 \%$ & 201 & 195 & $3 \%$ \\
\hline $57^{\circ}$ & 331 & 71 & $79 \%$ & 43 & 30 & $30 \%$ & 206 & 167 & $19 \%$ \\
\hline $78^{\circ}$ & 579 & 86 & $85 \%$ & 26 & 29 & $0 \%$ & 184 & 172 & $7 \%$ \\
\hline $87^{\circ}$ & 204 & 50 & $76 \%$ & 36 & 32 & $13 \%$ & 125 & 135 & $0 \%$ \\
\hline $108^{\circ}$ & 142 & 56 & $60 \%$ & 35 & 21 & $41 \%$ & 106 & 142 & $0 \%$ \\
\hline $116^{\circ}$ & 453 & 85 & $81 \%$ & 35 & 17 & $51 \%$ & 161 & 165 & $0 \%$ \\
\hline $135^{\circ}$ & 196 & 31 & $84 \%$ & 18 & 16 & $15 \%$ & 140 & 145 & $0 \%$ \\
\hline $159^{\circ}$ & 476 & 47 & $90 \%$ & 15 & 16 & $0 \%$ & 157 & 153 & $3 \%$ \\
\hline $174^{\circ}$ & 297 & 34 & $89 \%$ & 29 & 29 & $2 \%$ & 100 & 100 & $1 \%$ \\
\hline $180^{\circ}$ & 107 & 22 & $80 \%$ & 20 & 9 & $56 \%$ & 90 & 107 & $0 \%$ \\
\hline $195^{\circ}$ & 97 & 24 & $75 \%$ & 17 & 21 & $0 \%$ & 131 & 95 & $28 \%$ \\
\hline Média & 273 & 64 & $77 \%$ & 31 & 32 & $0 \%$ & 155 & 141 & $9 \%$ \\
\hline $\begin{array}{l}\text { Desvio } \\
\text { Padrão }\end{array}$ & 165 & 31 & & 14 & 15 & & 43 & 32 & \\
\hline Máximo & 579 & 164 & $90 \%$ & 73 & 59 & $64 \%$ & 229 & 195 & $50 \%$ \\
\hline Mínimo & 60 & 22 & $22 \%$ & 13 & 9 & $0 \%$ & 90 & 85 & $0 \%$ \\
\hline
\end{tabular}


ANEXO C - Tabela com valores de alcalinidade a bicarbonato e ácidos voláteis totais.

\begin{tabular}{|c|c|c|c|c|}
\hline \multirow[t]{2}{*}{$\begin{array}{c}\text { Ciclo } \\
\text { analisado }\end{array}$} & \multicolumn{2}{|c|}{$\begin{array}{c}\text { Alcalinidade } \\
\text { Bicarbonato } \\
\text { (mg/L de } \mathrm{CaCO} 3 \text { ) }\end{array}$} & \multicolumn{2}{|c|}{$\begin{array}{l}\text { Ácidos Voláteis } \\
\text { Totais } \\
\text { (mg/L de H.Ác.) }\end{array}$} \\
\hline & Afluente & Efluente & Afluente & Efluente \\
\hline 50 & 95 & 190 & 41 & 43 \\
\hline 8은 & 89 & 172 & 52 & 68 \\
\hline $12^{\circ}$ & 87 & 117 & 33 & 73 \\
\hline $20^{\circ}$ & 133 & 204 & 59 & 52 \\
\hline $24^{\circ}$ & 143 & 212 & 42 & 57 \\
\hline $30^{\circ}$ & 171 & 228 & 34 & 46 \\
\hline $36^{\circ}$ & 75 & 212 & 82 & 63 \\
\hline $45^{\circ}$ & 109 & 208 & 53 & 70 \\
\hline 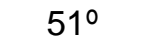 & 182 & 227 & 65 & 73 \\
\hline $56^{\circ}$ & 202 & 274 & 72 & 73 \\
\hline $57^{\circ}$ & 131 & 251 & 73 & 96 \\
\hline $78^{\circ}$ & 115 & 206 & 73 & 80 \\
\hline $87^{\circ}$ & 115 & 235 & 54 & 71 \\
\hline $93^{\circ}$ & 106 & 275 & 50 & 68 \\
\hline $99^{\circ}$ & 131 & 272 & 56 & 86 \\
\hline $108^{\circ}$ & 142 & 281 & 50 & 68 \\
\hline $116^{\circ}$ & 143 & 294 & 71 & 70 \\
\hline $128^{\circ}$ & 133 & 270 & 61 & 70 \\
\hline $135^{\circ}$ & 138 & 222 & 50 & 82 \\
\hline $141^{\circ}$ & 96 & 242 & 62 & 93 \\
\hline $149^{\circ}$ & 107 & 257 & 51 & 74 \\
\hline $159^{\circ}$ & 150 & 272 & 49 & 80 \\
\hline $174^{\circ}$ & 151 & 281 & 43 & 75 \\
\hline $180^{\circ}$ & 175 & 307 & 39 & 46 \\
\hline $195^{\circ}$ & 167 & 277 & 46 & 42 \\
\hline Média & 131 & 240 & 54 & 69 \\
\hline $\begin{array}{l}\text { Desvio } \\
\text { Padrão }\end{array}$ & 32 & 44 & 13 & 15 \\
\hline Máximo & 202 & 307 & 82 & 96 \\
\hline Mínimo & 75 & 117 & 33 & 42 \\
\hline
\end{tabular}


ANEXO D - Tabela do monitoramento de sólidos totais, suspensos e dissolvidos.

\begin{tabular}{|c|c|c|c|c|c|c|c|c|c|c|c|c|c|c|c|c|c|c|}
\hline \multirow{2}{*}{$\begin{array}{c}\text { Ciclo } \\
\text { analisado }\end{array}$} & \multicolumn{2}{|c|}{ ST } & \multicolumn{2}{|c|}{ STF } & \multicolumn{2}{|c|}{ STV } & \multicolumn{2}{|c|}{ SST } & \multicolumn{2}{|c|}{ SSF } & \multicolumn{2}{|c|}{ SSV } & \multicolumn{2}{|c|}{ SDT } & \multicolumn{2}{|c|}{ SDF } & \multicolumn{2}{|c|}{ SDV } \\
\hline & Afluente & Efluente & Afluente & Efluente & Afluente & Efluente & Afluente & Efluente & Afluente & Efluente & Afluente & Efluente & Afluente & Efluente & Afluente & Efluente & Afluente & Efluente \\
\hline $5^{0}$ & 459 & 651 & 362 & 281 & 97 & 370 & 47 & 59 & 5 & 69 & 42 & 0 & 412 & 592 & 357 & 212 & 55 & 370 \\
\hline $8^{\circ}$ & 335 & 572 & 134 & 553 & 201 & 19 & 42 & 33 & 10 & 0 & 32 & 33 & 293 & 539 & 124 & 553 & 169 & \\
\hline $12^{\circ}$ & 351 & 487 & 109 & 222 & 242 & 265 & 54 & 32 & 4 & 3 & 50 & 29 & 297 & 455 & 105 & 219 & 192 & 236 \\
\hline $20^{\circ}$ & 539 & 558 & 112 & 209 & 427 & 349 & 97 & 37 & 7 & 0 & 90 & 37 & 442 & 521 & 105 & 209 & 337 & 312 \\
\hline $24^{\circ}$ & 490 & 502 & & 327 & 490 & 175 & 184 & 34 & 26 & 0 & 158 & 34 & 306 & 468 & & 327 & 332 & 141 \\
\hline $30^{\circ}$ & 466 & 737 & 425 & 668 & 41 & 69 & 147 & 95 & 27 & 17 & 120 & 78 & 319 & 642 & 398 & 651 & & \\
\hline $36^{\circ}$ & 568 & 659 & 187 & 416 & 381 & 243 & 125 & 61 & 19 & 7 & 106 & 53 & 443 & 598 & 168 & 409 & 275 & 190 \\
\hline $45^{\circ}$ & 582 & 610 & 206 & 226 & 376 & 384 & 251 & 61 & 29 & 8 & 222 & 53 & 331 & 549 & 177 & 218 & 154 & 331 \\
\hline $51^{\circ}$ & 549 & 623 & 139 & 248 & 410 & 375 & 110 & 43 & 7 & 1 & 103 & 43 & 439 & 580 & 132 & 247 & 307 & 332 \\
\hline $56^{\circ}$ & 955 & 969 & 423 & 520 & 532 & 449 & 280 & 54 & 33 & 1 & 247 & 53 & 675 & 915 & 390 & 519 & 285 & 396 \\
\hline $57^{\circ}$ & 766 & 1044 & 471 & 502 & 295 & 542 & 186 & 48 & 24 & 6 & $\begin{array}{l}162 \\
162\end{array}$ & 41 & 580 & 996 & 447 & 496 & 133 & 501 \\
\hline $78^{\circ}$ & 647 & 642 & 41 & 163 & 606 & 479 & 291 & 50 & 48 & 1 & 243 & 49 & 356 & 592 & & 162 & 363 & 430 \\
\hline $87^{\circ}$ & 420 & 768 & 128 & 255 & 292 & 513 & 108 & 26 & 13 & 0 & 95 & 26 & 312 & 742 & 115 & 255 & 197 & 487 \\
\hline $93^{\circ}$ & 413 & 583 & 184 & 316 & 229 & 267 & 88 & 39 & 8 & 3 & 80 & 36 & 325 & 544 & 176 & 313 & 149 & 231 \\
\hline $99^{\circ}$ & 880 & 1010 & 547 & $\begin{array}{l}713 \\
713\end{array}$ & 333 & 297 & $\begin{array}{l}100 \\
101\end{array}$ & 34 & 15 & 2 & 86 & 32 & $\begin{array}{l}779 \\
779\end{array}$ & 976 & 532 & 711 & 247 & 265 \\
\hline $108^{\circ}$ & 527 & 871 & 127 & 289 & 400 & 582 & 84 & 46 & 13 & 5 & 71 & 41 & 443 & 825 & 114 & 284 & 329 & 541 \\
\hline $116^{\circ}$ & 659 & 763 & 278 & 380 & 381 & 383 & 250 & 60 & 40 & 3 & 210 & 57 & 409 & 703 & 238 & 377 & 171 & 326 \\
\hline $128^{\circ}$ & 714 & 759 & 273 & 408 & 441 & 351 & 145 & 26 & 24 & 0 & 121 & 26 & 569 & 733 & 249 & 408 & 320 & 325 \\
\hline $135^{\circ}$ & 837 & 814 & 539 & 593 & 298 & 221 & 104 & 31 & 16 & 3 & 88 & 28 & 733 & 783 & 523 & 590 & 210 & 192 \\
\hline $141^{\circ}$ & 666 & 810 & 809 & 581 & 374 & 229 & 110 & 34 & 18 & 4 & 92 & 30 & 810 & 776 & 473 & 577 & 337 & 199 \\
\hline $149^{\circ}$ & 496 & 621 & 46 & 234 & 450 & 387 & 116 & 33 & 20 & 3 & 96 & 30 & 380 & 588 & 26 & 231 & 354 & 357 \\
\hline $159^{\circ}$ & 910 & 1135 & 375 & 509 & 535 & 626 & 243 & 23 & 44 & 3 & 199 & 20 & 667 & 1112 & 331 & 506 & 336 & 606 \\
\hline $174^{\circ}$ & 632 & 757 & 218 & 345 & 414 & 412 & 164 & 31 & 27 & 3 & 137 & 28 & 468 & 726 & 191 & 343 & 277 & 383 \\
\hline $180^{\circ}$ & 507 & 849 & 279 & 624 & 228 & 225 & 41 & 20 & 7 & 4 & 34 & 16 & 466 & 829 & 272 & 620 & 194 & 209 \\
\hline Média & 599 & 741 & 279 & 399 & 353 & 342 & 140 & 42 & 20 & 6 & 120 & 36 & 469 & 699 & 256 & 393 & 249 & 335 \\
\hline $\begin{array}{l}\text { Desvio } \\
\text { Padrão }\end{array}$ & 173 & 173 & 190 & 164 & 135 & 151 & 76 & 17 & 12 & 14 & 64 & 16 & 160 & 176 & 151 & 166 & 87 & 124 \\
\hline Máximo & 955 & 1135 & 809 & 713 & 606 & 626 & 291 & 95 & 48 & 69 & 247 & 78 & 810 & 1112 & 532 & 711 & 363 & 606 \\
\hline Mínimo & 335 & 487 & 41 & 163 & 41 & 19 & 41 & 20 & 4 & 0 & 32 & 0 & 293 & 455 & 26 & 162 & 55 & 141 \\
\hline
\end{tabular}


ANEXO E - Tabela com valores obtidos nos perfis temporais para pH, DQO, POR, AB e AVT.

\begin{tabular}{|c|c|c|c|c|c|c|c|c|c|c|c|c|}
\hline \multirow{2}{*}{$\begin{array}{c}\text { Tempo } \\
\text { (hora) }\end{array}$} & \multirow{2}{*}{$\mathrm{pH}_{\text {anál. }}$} & \multicolumn{3}{|c|}{ DQO (mg/L) } & \multicolumn{3}{|c|}{ DQO fracionada (mg/L) } & \multirow{2}{*}{$\begin{array}{c}\text { Tempo } \\
\text { (hora) }\end{array}$} & \multirow{2}{*}{$\begin{array}{l}\text { POR } \\
(\mathrm{mV})\end{array}$} & \multirow{2}{*}{$\begin{array}{c}\text { Tempo } \\
\text { (hora) }\end{array}$} & \multirow{2}{*}{$\begin{array}{c}A B \\
(m g / L)^{*}\end{array}$} & \multirow{2}{*}{$\begin{array}{c}\text { AVT } \\
(\mathrm{mg} / \mathrm{L})^{* *}\end{array}$} \\
\hline & & Bruta & Filtr.\#1,2 & Filtr.\#0,45 & Particulada & Coloidal & Solúvel & & & & & \\
\hline 0,00 & 7,3 & 466 & 221 & 187 & 245 & 34 & 187 & 0,00 & -113 & 0,00 & 103 & 49 \\
\hline 0,18 & 7,5 & 343 & 165 & 140 & 178 & 26 & 140 & 0,05 & -294 & 0,20 & 214 & 38 \\
\hline 0,43 & 7,6 & 325 & 189 & 138 & 137 & 51 & 138 & 0,13 & -308 & 0,45 & 176 & 51 \\
\hline 0,68 & 7,6 & 288 & 168 & 135 & 120 & 33 & 135 & 0,25 & -316 & 0,70 & 189 & 56 \\
\hline 0,93 & 7,6 & 262 & 159 & 130 & 103 & 29 & 130 & 0,30 & -318 & 0,95 & 176 & 52 \\
\hline 1,18 & 7,6 & 241 & 172 & 130 & 69 & 42 & 130 & 0,50 & -323 & 1,45 & 179 & 79 \\
\hline 1,68 & 7,7 & 219 & 152 & 126 & 67 & 26 & 126 & 0,75 & -329 & 1,95 & 225 & 73 \\
\hline 2,18 & 7,7 & 195 & 152 & 123 & 44 & 29 & 123 & 1,00 & -347 & 2,95 & 227 & 68 \\
\hline 2,68 & 7,7 & 193 & 147 & 117 & 46 & 30 & 117 & 1,50 & -348 & 3,95 & 232 & 84 \\
\hline 3,18 & 7,7 & 180 & 148 & 119 & 33 & 29 & 119 & 2,00 & -361 & 4,95 & 285 & 74 \\
\hline 3,68 & 7,7 & 176 & 131 & 116 & 45 & 15 & 116 & 2,50 & -343 & 5,95 & $\star * \star$ & 86 \\
\hline 4,18 & 7,7 & 169 & 129 & 123 & 41 & 6 & 123 & 3,00 & -339 & 6,95 & 292 & 89 \\
\hline 4,68 & 7,7 & 170 & 128 & 122 & 41 & 6 & 122 & 3,50 & -341 & 7,80 & 289 & 87 \\
\hline 5,18 & 7,7 & 170 & 127 & 121 & 43 & 7 & 121 & 4,50 & -372 & & & \\
\hline 5,68 & 7,7 & 170 & 126 & 120 & 44 & 6 & 120 & 5,57 & -404 & ${ }^{*}$ como & $\mathrm{aCO}_{3}$ & \\
\hline 6,68 & 7,7 & 166 & 127 & 122 & 39 & 6 & 122 & 6,57 & -411 & ** como & Н.Ác. & \\
\hline 7,80 & 7,7 & 169 & 129 & 121 & 40 & 8 & 121 & 7,60 & -411 & *** análi & e incorreta & \\
\hline
\end{tabular}

Observação: os valores do tempo são diferentes para os parâmetros analisados porque foram realizados perfis em datas e intervalos horários diferentes 


\section{REFERÊNCIAS BIBLIOGRÁFICAS}

ALIBHAI, K.R.K.; FORSTER, C.F. (1986). An examination of the granulation process in UASB reactors. Environmental Technology Letters, v.7, p.193-200.

ANGENENT, L.T.; DAGUE, R.R. (1995). A laboratory-scale comparison of the UASB and ASBR processes. In: PURDUE INDUSTRIAL WASTE CONFERENCE PROCEEDING, 50., Ann Arbor Press, Chelsea, Michigan, p.365-77.

ANGENENT, L.T.; SUNG, S.; RASKIN, L. (2002a). Methane yield and methanogen levels of ASBR systems treating swine waste: effect of different inocula. In: TALLER Y SIMPOSIO LATINOAMERICANO SOBRE DIGESTIÓN ANAEROBIA, 7., Mérida, 2002. Anais. Yucatán, México, p.253-60.

ANGENENT, L.T.; SUNG, S.; RASKIN, L. (2002b). Methanogenic population dynamics during startup of a full-scale anaerobic sequencing batch reactor treating swine waste. Water Research, v.36, 4648-54.

ARAÚJO, J.C. (1995). Caracterização e evolução de biofilme em reator anaeróbio de leito fluidificado alimentado com esgoto sanitário sintético. São Carlos. 158p. Dissertação (mestrado) - Escola de Engenharia de São Carlos, Universidade de São Paulo.

BAGLEY, D.M.; BRODKORB, T.S. (1999). Modeling microbial kinetics in an anaerobic sequencing batch reactor - model development and experimental validation. Water Environment Research, v.71, n.7, p.1320-32.

BALAGUER, M. D.; VINCENT, M. T.; PARIS, J. M. (1991) Utilisation of pumice stone as support for the anaerobic treatment of vinasse with a fluidized bed reactor. Environmental Technology, v.12, p.1167-73.

BANIK, G.C.; DAGUE, R.R. (1997). ASBR treatment of low strength industrial wastewater at psychrophilic temperatures. Water Science and Technology, v.36, n.2-3, p.337-44. 
BANIK, G.C.; ELLIS, T.G.; DAGUE, R.R. (1997). Structure and methanogenic activity of granules from an ASBR treating dilute wastewater at low temperatures. Water Science and Technology, v.36, n.6-7, p.149-56.

BEVILACQUA, P.; FERRERA, G. (1996). Comminution of porous materials. International Journal of Mineral Processing, v.44-45, p.117-31.

BISHOP, P.L.; YU, T. (1999). A microelectrode study of redox potential change in biofilms. Water Science Technology, v.39, n.7, p.179-85.

BORZANI, W.; LIMA, U.A.; AQUARONE, E. (1986). Engenharia Bioquímica. 1.ed., v.3. São Paulo, Edgard Blucher.

BRITO, A.G.; RODRIGUES, A.C.; MELO, L.F. (1997). Feasibility of a pulsed sequencing batch reactor with anaerobic aggregated biomass for the treatment of low strength wastewaters. Water Science and Technology, v.35, n.1, p.193-8.

BROCK, T.D.; MADIGAN, M.T.; MARTINKO, J.M.; PARKER, J. (1995). Brock - biology of microorganisms. 7.ed. New Jersey, Prentice Hall.

BRYERS, J.D. (1988). Modeling biofilm accumulation. In: BAZIN, M.J.; DROSSER, J.I. ed. "Physiological models in microbiology", v.2, Series in Mathematical Models in Microbiology, CRC Press, Boca Raton, Florida, p.109-44.

CAMPOS, J.R. (1994). Biomassa fixa: reatores anaeróbios. In: TALLER Y SEMINÁRIO LATINOAMERICANO "TRATAMIENTO ANAEROBIO DE AGUAS RESIDUALES”, 3., Montevideo, 1994. Anais. Uruguai, p.184-96.

COSTERTON, J.W.; GEESEY, G.G.; CHENG, K.J. (1978). How bacteria stick. Science American, v.238, p.86-95.

COSTERTON, J.W.; LEWANDOWSKI, Z.; CALDWELL, D.E.; KORBER, D.R.; LAPPIN-SCOTT, H.M. (1995). Microbial biofilms. Annual Reviews in Microbiology, v.49, p.711-45.

CUBAS, S.A.; FORESTI, E.; RODRIGUES, A.D.; RATUSZNEI, S.M.; ZAIAT, M. (2001). Influence of the liquid-phase mass transfer on the performance of a stirred anaerobic sequencing batch reactor containing immobilized biomass. In: WORLD CONGRESS ANAEROBIC DIGESTION, 9., Antwerpen, 2001. Anais. Belgium, IWA, p.847-52. 
CUBAS, S.A.; PINHO, S.C.; FORESTI, E.; RODRIGUES, J.A.D.; RATUSZNEI, S.M.; ZAIAT, M. (2002). Effects of solid-phase mass transfer on a stirred anaerobic sequencing batch reactor containing immobilized biomass. In: TALLER Y SIMPOSIO LATINOAMERICANO SOBRE DIGESTIÓN ANAEROBIA, 7., Mérida, 2002. Anais. Yucatán, México, p.229-36.

DAGUE, R.R.; BANIK, G.C.; ELLIS, T.G. (1998). Anaerobic sequencing batch reactor treatment of dilute wastewater at psychrophilic temperatures. Water Environment Research, v.70, n.2, p.155-60.

DAGUE, R.R.; HABBEN, C.E.; PIDAPARTI, S.R. (1992). Initial studies on the anaerobic sequencing batch reactor. Water Science and Technology, v.26, n.9-11, p.2429-32.

De Los REYES III, F.L.; DAGUE, R.R. (1995). Effects of initial seed concentration on the startup of the anaerobic sequencing batch reactor. In: PURDUE INDUSTRIAL WASTE CONFERENCE PROCEEDINGS, 50., Ann Arbor Press, Chelsea, Michigan, p.439-59.

DICTOR, M. C.; BATTAGLIA-BRUNET, F.; MORIN, D.; BORIES, A.; ClARENS, M. (1997). Biological treatment of gold ore cyanidation wastewater in fixed bed reactors. Environmental Pollution, v.97, n.3, p.287-94.

DILALLO, R.; ALBERTON, O.E. (1961). Volatile Acids by Direct Tritation. Journal Water Pollution Control Federation, v.33, p.356-65.

DROSTE, R.L; MASSÉ, D.I. (1995). Anaerobic treatment in sequencing batch reactors. In: INTERNATIONAL SYMPOSIUM ON TECHNOLOGY TRANSFER, Salvador, Bahia, Brazil, p.353-63.

DUGBA, P.N.; ZHANG, R.H. (1999). Treatment of dairy wastewater with two-stage anaerobic sequencing batch reactor systems - thermophilic versus mesophilic operations. Bioresource Technology, v.68, p.225-33.

FERNANDES, L.; KENNEDY, K.J.; NING, Z. (1993). Dynamic modelling of substrate degradation in sequencing batch anaerobic reactors (SBAR). Water Research, v.27, n.11, p.1619-28.

FIGUEIREDO, M.G.; VAZOLLER, R.F. (1991). Inibição da redução do íon sulfato no tratamento anaeróbio de resíduos. Relatório Científico. CETESB, 68p. 
HARENDRANATH, C. S.; ANUJA, K.; SINGH, A.; GUNASEELAN, A.; SATISH, K.; LALA, K. (1996). Immobilization in fixed film reactors: an ultrastructural approach. Water Science and Technology, v.33, n.8, p.7-15.

HARPER, S.R.; POHLAND, F.G. (1986). Recent developments in hydrogen management during anaerobic biological wastewater treatment. Biotechnology and Bioengineering, v.28, p.585-602.

HIRL, P.J.; IRVINE, R.L. (1996). Reductive dechlorination of perchloroethylene (PCE) using anaerobic sequencing batch biofilm reactors (AnSBBR). In: PURDUE INDUSTRIAL WASTE CONFERENCE PROCEEDINGS, 51., Ann Arbor Press, Chelsea, Michigan, p.289-95.

HOLLOPETER, J.A.; DAGUE, R.R. (1994). Anaerobic sequencing batch reactor treatment of landfill leachate. In: PURDUE INDUSTRIAL WASTE CONFERENCE PROCEEDINGS, 49., Chelsea, 1994. Anais. Ann Arbor Press, Michigan, p.277-84.

JENKINS, D; RICHARD, M.G.; DAIGGER, G.T. (1993). Manual on the causes and control of activated sludge bulking and foaming. 2.ed. Michigan, Lewis Publishers.

JENKINSON, H.J.; LAPPIN-SCOTT, H.M. (2001). Biofims a here to stay. Trends in Microbiology, v.9, n.1, p.9-10.

MASSÉ, D.; MASSÉ, L. (2001). The effect of temperature on slaughterhouse wastewater treatment in anaerobic sequencing batch reactors. Bioresource Technology, v.76, p.91-8.

MASSÉ, D.I.; DROSTE, R.L. (1997). Microbial interaction during the anaerobic treatment of swine manure slurry in a sequencing batch reactor. Canadian Agricultural Engineering, v.39, n.1, p.35-41.

MASSÉ, D.I.; DROSTE, R.L.; KENNEDY, K.J.; PATNI, N.K.; MUNROE, J.A. (1997). Potential for the psychrophilic anaerobic treatment of swine manure using a sequencing batch reactor. Canadian Agricultural Engineering, v.39, n.1, p.25-33.

MASSÉ, D.I.; PATNI, N.K.; DROSTE, R.L.; KENNEDY, K.J. (1996). Operation strategies for psychrophilic anaerobic digestion of swine manure slurry in sequencing batch reactors. Canadian Journal of Civil Engineering., v.23, p.1285-94. 
MENDONÇA, N. M. (1999) Caracterização do material suporte e estudo da partida de um reator anaeróbio de leito expandido utilizado no tratamento de esgoto sanitário. São Carlos. 191p. Dissertação (mestrado) - Escola de Engenharia de São Carlos, Universidade de São Paulo.

MERAZ, M.; MONROY, O.; NOYOLA, A.; ILANGOVAN, K. (1995). Studies on the dynamics of immobilization of anaerobic bacteria on a plantic support. Water Science and Technology, v.32, n.8, p.243-50.

NATION, J.L. (1983). A new method using hexamethyldisilazane for preparation of soft tissues for scanning electron microscopy. Stain Technology, v.58, p.347-51.

NDON, U.J.; DAGUE, R.R. (1997a). Effects of temperature and hydraulic retention time on anaerobic sequencing batch reactor treatment of low-strength wastewater. Water Research, v.31, n.10, p.2455-66.

NDON, U.J.; DAGUE, R.R. (1997b). Ambient temperature treatment of low strength wastewater using anaerobic sequencing batch reactor. Biotechnology Letters, v.19, n.4, p.319-23.

NOVAES, R.F.V. (1986). Microbiology of anaerobic digestion. Water Science Technology, v.18, p.1-14.

PASSIG, F. H. (1997). Estudo do desenvolvimento do biofilme e dos grânulos formados no filtro biológico anaeróbio. São Carlos. 128p. Dissertação (mestrado) - Escola de Engenharia de São Carlos, Universidade de São Paulo.

PATEL, P.; PATEL, C.; MADAMWAR, D. (1999). Anaerobic upflow fixed-film bioreactor for biomethanation of salty cheese whey. Applied Biochemistry and Biotechnology, v.76, p.193-201.

PEREIRA, J.A.R.; CAMPOS, J.R.; GIANOTTI, E.P.; MENDONÇA, N.M. (1997). Aderência de microrganismos em partículas de carvão ativado utilizadas no tratamento de esgoto sanitário. In: CONGRESSO BRASILEIRO DE ENGENHARIA SANITÁRIA E AMBIENTAL, Foz do Iguaçu, 1997. Anais. ABES. P.552-9.

PFENNIG, N. (1978). General physiology and ecology of photosynthetic bacteria. In: CLAYTON, R.K.; SISTROM, W.R. The Photosynthetic Bacteria. Plenum, New York. P.3-18. 
PINHO, S.C.; CUBAS, S.A.; RATUSZNEI, S.M.; RODRIGUES, J.A.D.; FORESTI, E.; ZAIAT, M. (2002). Influence of the agitation rate on the treatment of partially soluble wastewater in anaerobic sequencing batch reactor containing immobilized biomass. In: TALLER Y SIMPOSIO LATINOAMERICANO SOBRE DIGESTIÓN ANAEROBIA, 7., Mérida, 2002. Anais. Yucatán, México, p.103-6.

QUAGLIANO, J.V.; VALLARINO, L.M. (1979). Química. Trad. Por Aïda Espinola. 3.ed. Rio de Janeiro, Guanabara Dois. Cap.31, p.700-15: Os metais alcalino-terrosos: elementos do grupo II-A.

RACHEL, A.; LAVEDRINE, B.; SUBRAHMANYAM, M.; BOULE, P. (2002). Use of porous lavas as supports of photocatalysts. Catalysis Communications, v.3, p.165-71.

RATUSZNEI, S.M.; RODRIGUES, J.A.D; ZAIAT, M. (2002). Operating feasibility of anaerobic whey treatment in a stirred sequencing batch reactor containing immobilized biomass. In: TALLER Y SIMPOSIO LATINOAMERICANO SOBRE DIGESTIÓN ANAEROBIA, 7., Mérida, 2002. Anais. Yucatán, México, p.330-7.

RATUSZNEI, S.M.; RODRIGUES, J.A.D.; CAMARGO, E.F.M.; ZAIAT, M.; BORZANI, W. (2000). Feasibility of a stirred anaerobic sequencing batch reactor containing immobilized biomass for wastewater treatment. Bioresource Technology, v.75, p.127-32.

RATUSZNEI, S.M.; RODRIGUES, J.A.D.; CAMARGO, E.F.M.; ZAIAT, M.; BORZANI, W. (2001). Influence of agitation rate on the performance of a stirred anaerobic sequencing batch reactor containing immobilized biomass. Water Science and Technology, v.44, n.4, p.305-12.

RIBEIRO, R. (2001). Influência do tipo de substrato na dinâmica de formação do biofilme em matrizes de espuma de poliuretano. São Carlos. 193p. Dissertação (mestrado) Escola de Engenharia de São Carlos, Universidade de São Paulo.

RIPLEY, L.E.; BOYLE, W.C.; CONVERSE, J.C. (1986). Improved alkalimetric monitoring for anaerobic digestion of high-strength wastes. Journal Water Pollution Control Federacion, v.58, n.5, p.406-11.

RODRIGUES, J.A.D.; RATUSZNEI, S.M.; CAMARGO, E.F.M.; ZAIAT, M. (2003). Influence of agitation rate on the performance of na anaerobic sequencing batch reactor 
containing granulated biomass treating low-strentgh wastewater. Advances in Environmental Research, v.7, n.2, p.405-10.

RODRÍGUEZ, G.C.; BARCELÓ, Ó.G.; MATINEZ, S.G. (1998). Wastewater fermentation and nutrient removal in sequencing batch reactors. Water Science and Technology, v.38, n.1, p.255-64.

SARTI, A.; GARCIA, M.L.; ZAIAT, M.; FORESTI, E. (2002). Avaliação do desempenho do reator anaeróbio em batelada com biomassa imobilizada no tratamento de esgoto sanitário. In: TALLER Y SIMPOSIO LATINOAMERICANO SOBRE DIGESTIÓN ANAEROBIA, 7., Mérida, 2002. Anais. Yucatán, México, p.111-4.

SCHIMIT, C.G.; DAGUE, R.R. (1993). Anaerobic sequencing batch reactor treatment of swine wastes at $20^{\circ} \mathrm{C}, 25^{\circ} \mathrm{C}$, and $35^{\circ} \mathrm{C}$. In: PURDUE INDUSTRIAL WASTE CONFERENCE PROCEEDING, 48., Ann Arbor Press, Chelsea, Michigan, p.541-549.

SHIZAS, I.; BAGLEY, D. M. (2002). Improving anaerobic sequencing batch reactor performance by modifying operational parameters. Water Research, v.36, p.363-7.

SILVA, A.J.; HIRASAWA, J.S.; VARESCHE, M.B.; FORESTI, E.; ZAIAT, M. (2002). Evaluation of support materials for the immobilization of sulphate-reducing bacteria and methanogenic archaea. In: TALLER Y SIMPOSIO LATINOAMERICANO SOBRE DIGESTIÓN ANAEROBIA, 7., Mérida, 2002. Anais. Yucatán, México, p.47-50.

SNOEYINK, V.; JENKINS, D. (1935). Water Chemistry. USA, John Wiley \& Sons. Cap.6, 243-315: Precipitation and dissolution.

SPEECE, R.E. (1996). Anaerobic biotechnology for industrial wastewater. Nashville, Archae Press.

STUMM, W.; MORGAN, J.J. (1924). Aquatic Chemistry - An Introduction Emphasizing Chemical Equilibria in Natural Waters. USA, John Wiley \& Sons. Cap.9, 523-98: The Regulation of the Chemical Composition of Natural Waters.

SUNG, S.; DAGUE, R.R. (1995). Laboratory studies on the anaerobic sequencing batch reactor. Water Environment Research, v.67, n.3, p.294-301.

TIMUR, H.; ÖZTURK, I. (1999). Anaerobic sequencing batch reactor treatment of landfill leachate. Water Research, v.33, n.15, p.3225-30. 
TOMMASO, G.; VARESCHE, M.B.; ZAIAT, M.; VAZOLLER, R.F.; FORESTI, E. (2002). Morphological observation and microbial population dynamics in anaerobic polyurethane foam biofilm degrading gelatin. Brazilian Journal of Chemical Engineering, v.19, n.3, p.287-92.

VALLERO, M. V. G.; BLUNDI, C. E.; ZAIAT, M. (2000). Biologic activity analysis of free and attached cells formed in an anaerobic upflow reactor. In: INTERNATIONAL SYMPOSIUM ON ENVIRONMENTAL BIOTECHNOLOGY, 4., Noordwijkerhout, the Netherlands, p.302-5.

Van LOOSDRECHT, M.C.M.; LYKLEMA, J.; NORDE, W.; SCHRAA, G.; ZEHNDER, A.J.B. (1987). The role of bacterial cell wall hydrophobicity in adhesion. Applied and Environmental Microbiology, v.53, n.8, p.1893-7.

Van LOOSDRECHT, M.C.M.; LYKLEMA, J.; NORDE, W.; ZEHNDER, A.J.B. (1990). Influence of interfaces on microbial activity. Microbiological Reviews, v.54, n.1, p.7587.

VARESCHE, M.B. (1997). Estudo com bactérias fototróficas anoxigênicas: enriquecimento, isolamento, caracterização nutricional e cinética de crescimento. São Carlos. 363p. Tese (Doutorado) - Escola de Engenharia de São Carlos, Universidade de São Carlos.

VAZOLLER, R.F.; GARCIA, M.A.R.; GARCIA JR, A.D.; CONCEIÇÃO NETO, J. (1992). Microbiologia de lodos ativados. São Paulo, CETESB.

VERONEZ，R.G.; ORRA，A.A.; RIBEIRO， R.; ZAIAT，M.; RATUSZNEI， S.M.; RODRIGUES, A.J.D. (2002). Modification of granule characteristics in ASBR and UASB reactors treating low-strength wastewater. In: TALLER Y SIMPOSIO LATINOAMERICANO SOBRE DIGESTIÓN ANAEROBIA, 7., Mérida, 2002. Anais. Yucatán, México, p.51-54.

VERRIER, D.; MORTIER, B.; ALBAGNAC, G. (1987). Initial adhesion of methanogenic bacteria to polimers. Biotechnology Letters, v.9, n.10, p.735-40.

VERRIER, D.; MORTIER, B.; DUBOURGUIER, H.C.; ALBAGNAC, G. (1988). Adhesion of anaerobic bacteria to inert supports and devolpment of methangenic biofilms. In: INTERNATIONAL SYMPOSIUM ON ANAEROBIC DIGESTION, 5., London, 1988. Anais. Oxford, Pergamon Press, p.61-9. 
VIJAYALAKSHIMI, M.A.; COCHET, N.; LEBEAULT, J.M. (1990). Physicochemical aspects of cell adsorption. In: TYAGI, R.D.; VEMBU, K. ed. Wastewater Treatment by Immobilizad Cells. Ed. CRC Press, Boca Raton, Florida, cap.1, p.1-29.

WANG, M.L.; YANG, P.Y. (1990). Entrapment of microbial cells for wastewater treatment. In: TYAGI, R.D.; VEMBU, K. Wastewater Treatment by Immobilizad Cells. Ed. CRC Press, Boca Raton, Florida, cap.3, p.45-79.

WELPER, L.L.; SUNG,S.; DAGUE, R.R. (1997). Laboratory studies on the temperaturephased ASBR system. Water Science and Technology, v.36, n.2-3, p.295-302.

WIRTZ, R.A.; DAGUE, R.R. (1996). Enhancement of granulation and start-up in the anaerobic sequencing batch reactor. Water Environment Research, v.68, n.5, p.883-92.

WIRTZ, R.A.; DAGUE, R.R. (1997). Laboratory studies on enhancement of granulation in the anaerobic sequencing batch reactor. Water Science and Technology, v.36, n.4, p.27986.

ZAIAT, M.; RODRIGUES, J.A.D.; RATUSZNEI, S.M.; CAMARGO, E.F.M.; BORZANI, W. (2001). Anaerobic sequencing batch reactors for wastewater treatment: a developing technology. Applied Microbiol Biotechnology, v.55, p.29-35.

ZHANG, R.; YIN, Y.; SUNG, S.; DAGUE, R.R. (1997). Anaerobic treatment of swine waste by the anaerobic sequencing batch reactor. In: PURDUE INDUSTRIAL WASTE CONFERENCE PROCEEDINGS, 51., Chelsea, 1997. Anais. Ann Arbor Press, Chelsea, Michigan, p.315-20. 